\title{
The position of geochemical variables as causal co-factors of diseases of unknown aetiology
}

Theophilus Clavell Davies ( $\nabla$ theo.clavellpr3@gmail.com )

Mangosuthu University of Technology https://orcid.org/0000-0002-8299-1121

\section{Research Article}

Keywords: Unknown aetiology, geochemical perturbations, immune system, disease clusters, environmental risk maps

Posted Date: November 30th, 2021

DOl: https://doi.org/10.21203/rs.3.rs-1089540/v1

License: (1) This work is licensed under a Creative Commons Attribution 4.0 International License. Read Full License 


\section{Abstract}

The term diseases of unknown aetiology (DUA) or idiopathic diseases refers to diseases that are of uncertain or unknown cause or origin. Among plausible geoenvironmental (co-)factors in causation of DUA, this article focusses on the entry of trace elements, including metals and metalloids into biological systems, and their involvement in humoral and cellular immune responses, representing potentially toxic agents with implications as co-factors for certain DUA. Several trace elements/metals/metalloids (micronutrients) play vital roles as cofactors for essential enzymes and antioxidant molecules, thus, conferring protection against disease. However, inborn errors of trace element/metal/metalloid metabolisms can occur to produce toxicity, such as when there are basic defects in the element transport mechanism. Ultimately, it is the amount of trace element, metal or metalloid that is taken up, its mode of accumulation in human tissues, and related geomedical attributes such as the chemical form and bioavailability that decisively determine whether the exerted effects are toxic or beneficial. Several case descriptions of DUA that are common worldwide are given to illustrate our knowledge so far of how trace element/metal/metalloid interactions in the immune system may engender its dysregulation and be implicated as causal co-factors of DUA.

\section{Introduction}

An excerpt from Marcus Haase's paper in JAMA, "Etiology Unknown", written way back in 1923 runs as follows: "I doubt seriously whether there is a more humiliating moment in the life of a medical man, either as teacher or practitioner, than when asked by a student or patient, "What is the cause of this?" and he is forced to say, "I do not know." . Despite the enormous advances made by modern medicine, there are many diseases whose causes are still unknown (See examples in Table 1). These diseases are generally referred to as diseases of unknown aetiology (DUA), and as recently as 2020 , an estimated seventy-six percent of unknown disease outbreaks remained undiagnosed (Mao et al., 2020). Rappaport had earlier (2012) noted that: "Although chronic diseases are primarily environmental (i.e., not genetic) in origin, the particular environmental causes of these diseases are poorly understood."

A recent World Health Organisation (WHO) study of worldwide cancer mortality identified ten diverse environmental risk factors, including some with links to the geological environment, such as air pollution and ionising and ultraviolet radiation (WHO, 2018a). But, on the whole, it appears that the influence of geoenvironmental factors in disease causation, in particular, the effects of involvement of trace elements/metals/metalloids in human metabolisms that produce disease, have been somewhat underestimated.

In this paper, it is argued that greater consideration should be given to the contribution of the geoenvironmental co-factor in a multi-factor explanation and diagnosis of DUA; in particular, the entry of trace elements including metals and metalloids into biological systems, and their involvement in humoral and cellular immune responses. Possible ways in which trace elements/metals/metalloids can contribute towards shaping developmental metabolic frameworks

and pathways in DUA progression are described. The expectation is that a firm understanding of the role of geoenvironmental co-factors, more especially trace element/metal/metalloid perturbations that produce errors or disturbances in metabolic processes will help greatly in unravelling the aetiology of DUA when this knowledge is applied in a circumspective way.

Rationalisation of such knowledge falls within the compass of the Medical Geologist who, according to Bundschuh et al. (2017), can provide “... a more holistic understanding of the occurrence, mobility, bioavailability, bio-accessibility, exposure and transfer mechanisms of geochemicals to the food-chain and humans, and the related ecotoxicological impacts and health effects." To these parameters, can be added the chemical form of the element, a parameter that, in turn, greatly influences mobility, bioavailability and the mechanism that either transports the element to the centres (of the body) where it is needed for vital reactions, or be involved in interactions that result in disease (cf., DUA). Such an integrative approach recognises that most DUAs and other enigmatic diseases have multifactorial causes, engendering a complex interplay between genetic factors (polygenic), immunological mediators (trace elements/metals/metalloids) and various other (geo)environmental factors, none of which factors would cause the disease on its own.

This approach is further buttressed by Panelli's (2017) statement: "The focus on multisystem diseases of unknown cause highlights not only the immediate need in medicine to research the origin of an unknown disease with multiple symptoms, but also the necessity to find novel ways to diagnose and discriminate diseases that have no clear aetiology but represent a dramatic reality affecting large populations of patients."

\section{Methodology}

An iterative approach was adopted in a comprehensive internet search using Google search engine through August 26, 2021. Initial searches used broad terms: 'geo-environmental factors', 'unknown aetiology' and 'disease X'. Inclusion criteria were studies carried out in humans and animals and reported observational designs. The documents returned from these searches were used to identify narrower search terms, such as 'risk factors', 'nutritional and toxic elements/metabolic imbalances', 'immune system', 'geo-climatic variables and health', and 'disease clusters'. Over one thousand documents were retrieved (including some duplicates), out of which the conclusions of about six hundred and eighty were studied in detail. These included peer reviewed journal articles and conference proceedings, authentic book chapters, published and unpublished theses and reports, and selected web references.

\section{Main Text}




\section{Contributions made}

This paper has advanced reasons why a keener look at co-factors linked to the geoenvironmental mileu, especially geochemical variables, deserves greater attention in understanding causality of DUA. The medical profession, environmental health practitioners and allied scientists, relevant government officials and other stakeholders should now be aware of the huge potential contribution of Medical Geologists in teams investigating the causes of DUA and sudden disease outbreaks. The discourse fosters, in particular, an understanding of the relationship of certain trace elements/metals/metalloids and the immune system and presents examples of current critical evidence of associations between environmental risk factors such as geographical variables and climate change, and immune system impairment. The work buttresses the hypothesis that errors (or disturbances) in trace element/metal/metalloid metabolism negatively affect immune response and can provide useful clues in the unravelment of DUA causality. Consequently, it possible to proffer that a proper understanding of the dynamics/imbalances of trace element/metal/metalloid interactions in metabolic processes may one day be found to play a far greater role in deciphering DUA aetiology than has hitherto been realised.

Finally, a list of some of the more recent research (as at 2021) is assembled, supporting the thesis that greater consideration of geoenvironmental factors would enhance efforts in unravelling DUA aetiology. It is considered that this reference list would also prove useful as an aid to the search process of researchers interested in continuing with work on this important and exciting subject.

\section{A NOTE ON CAUSALITY}

In the field of medicine, cause, also sometimes referred to as aetiology is the reason or origination of a disease, or of a pathology (essential nature of

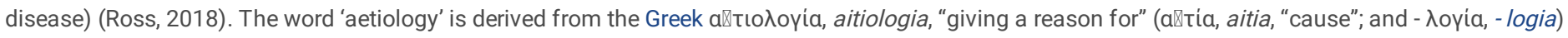
(Simpson and Weiner, 2002).

The search for the aetiologies of human diseases can be traced back to antiquity. Hippocrates, a Greek physician of the 4th and 5th centuries BCE, is credited with being the first to adopt the concept that disease is not a visitation of the gods but rather is caused by earthly influences (Britannica,

2020). Medieval European doctors were generally of the view that disease was related to the air and adopted a miasmatic approach to disease aetiology (Berry, 2007). Scientists have since continually searched for the causes of disease and, indeed, have discovered the causes of many. Where no aetiology can be ascertained, the disorder is said to be idiopathic (CMD, 2010).

Traditional accounts of the causes of disease may point to the evil eye, a phenomenon elucidated by Abu-Rabia in 2005, in describing the rituals of diagnosis, treatment and prevention among the Bedouin tribes of the Negev in the Middle East.

Aetiological discovery in medicine also has a history in Robert Koch's demonstration that the tubercle bacillus (Mycobacterium tuberculosis complex) causes the disease tuberculosis, Bacillus anthracis causes anthrax, and Vibrio cholerae causes cholera (Cambau and Drancourt, 2014). This line of thinking and evidence is summarised in Koch's postulates. In the epidemiology of infectious diseases, proof of causation is limited to individual cases where experimental evidence of aetiology can be advanced. In order to infer causation, we require several lines of evidence, taken together.

\section{Chain of causation and correlation}

We need to distinguish between causation and association or statistical correlation. Events may occur simultaneously simply due to chance, bias or confounding (See: "Glossary of Terms" for definitions), instead of one event being precipitated by the other. It is also necessary to decipher which event is the cause. Confounding is said to occur when exposure to a probable disease causative agent or cofactor and an outcome have an apparent but false correlation (Fig. 1). It is important to control for the confounder, otherwise, there would seem to be a link between the exposure and the outcome, when in fact both are due to the confounding effect and bear no relationship at all (or no strong relationship). Careful sampling and analyses should be the sine qua non, rather than complex statistical analysis to establish causation. Evidence from experimental studies involving interventions (providing or removing the supposed cause) provides the most convincing evidence of aetiology. 
It is also necessary to state that there are times when several symptoms appear together, sometimes more than what could be expected; though it is known that one cannot cause the other. These situations are referred to as syndromes (See "Glossary of Terms", this article). The assumption is that an underlying condition exists that explains all the symptoms. Quite often, however, a single cause for a disease cannot be found, but rather, we find a chain of causation from an initial trigger to the development of the clinical disease. An aetiological agent of disease may require an independent co-factor and be subject to a promoter (See "Glossary of Terms", this article) to cause disease.

\section{Role of genetics as causality co-factor}

A gene is the basic physical unit of heredity. Genes are made up of DNA (deoxytribonucleic acid) and act as instructions to synthesise molecules called proteins. Many proteins are actually enzymes, and are responsible for carrying out all cellular functions. Salzberg (2018) estimated the number of genes in the human genome (genetic complement) to be 20,000 to 25,000 . Genes are passed on from parents to offspring, and contain the information needed to specify traits.

Certain human diseases result from mutations in the genetic complement contained in the DNA of chromosomes. Although mutations occurring in the DNA of somatic (body) cells cannot be inherited, they can cause congenital malformations (existing at birth) and cancers. However, mutations that occur in germ cells

- i.e., the gametes, ova and sperm - are passed on to offspring causing inherited diseases.

Studies on how environmental exposures modify the expression of genes without directly changing the genetic code stored in DNA were appraised by Rappaport in 2016, and more recently by Perera et al. (2019). Such studies belong to the field of environmental epigenetics, a field that is currently being actively researched by the United States National Institute of Environmental Health Sciences (US NIEHS) (US NIEHS, 2020).

\section{THE GEO-ENVIRONMENT AS AN AGENT OF ILLNESS}

In 2000, Kroll-Smith et al. noted that: "Struggles over environmentally induced diseases are struggles over the very nature of what exists and how we know the nature of the phenomenon".

Suggestions that the geoenvironmental mileu (geographical and climatic patterns, seasonal variations, geological and geochemical variables) can have a significant influence on the occurrence and development of disease, has for long captivated scholarly attention across a number of disciplinary and policy domains. Mehri (2020), for instance, discuss how geoenvironmental conditions work in concert with infectious agents that activate innate and adaptive immune system (See "Glossary of Terms", this article) and provoke DUA in genetically susceptible patients.

Writing on one of the more well-known DUAs (chronic kidney disease, CKD: Table 1), Hara et al. (2016) remarked on the significance of the contribution of environmental factors compared to genetic factors in the development of CKD among individuals with the same ethnicity. In 2017, Senanayake and King, reviewing recent research done on emerging health-environment relationships, categorised the studies done into three themes, viz. complexity, uncertainty, and bodies. Although there have been robust contributions to these thematic areas from geography and the social sciences, Senanayake and King (2017) construe that integrating them into an analytical framework can extend geographical perspectives on scale, knowledge production, and human-environment relations, while also incorporating valuable insights from cognate fields.

The cardinal thesis here is that proper consideration of geoenvironmental co-factors can significantly contribute to resolution of causation of DUA, probably to an extent greater than what has hitherto been conceived (Table 1). Some examples of probable geoenvironmental and related co-factors to be considered are:

(i) The immune-modulatory effect of geochemical variables (e.g., chemical form and the mechanism of element transport) that underline nutritional and potentially toxic element (PTE) perturbations in metabolic processes.

Page $4 / 55$ 
(ii) Water, soil and air pollution emanating from diverse sources that include volcanic emissions, mining, naturally contaminated groundwater, agriculture and industry. A substantial part of the pollution load from these sources often comprises the PTEs (e.g., As, F, Hg, Pb) having a propensity to enter the food chain (through consumption of food crops, drinking water and through other intake pathways such as inhalation and direct contact) [cf., (i) above]. Initially undetected release of a chemical from the Earth's sub-surface into the groundwater system can occur, such as when $\mathrm{CO}_{2}$ gas was released in the Lake Nyos (Cameroon) disaster of the 1980's (See, e.g., Rouwet et al., 2016).

(iii) Geogenic dust particles (from mining, ore processing and vehicular transportation on untarred roads).

(iv) Over-exposure to ionising radiation and radionuclides in the water, soil and air environments during mining, ore processing and tailings handling of $\mathrm{U}$, Au and other radiogenic ores.

(v) Geographical patterns (e.g., locality, altitude) and seasonal variations.

(vi) Climate change and geoclimatic effects.

(vii) Factors of geopathic stress and heat stress.

\section{PLEASE INSERT TABLE 1 HERE}

Geogenic contaminants

Geochemicals such as metals, metalloids, radionuclides and isotopes as well as transuraniums, referred to as geogenic contaminants (GCs) by Bundschuh et al. (2017), occur naturally in geogenic sources (minerals, rocks, ground- and surface waters, volcanic emanations). Their accelerated release globally has been attributed to rapid population rise and economic growth, and the associated increase in demand for water, energy, food, and mineral resources. When GCs occur in near-surface environments, their release can be triggered into the environment by natural biogeochemical processes and/or by anthropogenic activities such as mining and oil exploitation, fossil fuel combustion as well as exploitation of geothermal resources. The result is the contamination of soil, water, air and biota, and their subsequent entry into the food chain with often deleterious health consequences that are mostly underestimated and poorly recognised; not to say that other categories of co-factors of environmental pollution are to be discounted, when studying environmental toxicology and pathogenesis. Indeed, Garchitorena et al. (2017) demonstrate clearly that: "Control of environmentally transmitted diseases can be more effective when human treatment is complemented with interventions targeting the environmental reservoir of the pathogen."

\section{Geographical patterns, seasonal variations and climate change}

As recently as 2008, Dummer recapitulated the intrinsical link between geography and health, and went on to posit that, where we were born, where we live, where we work, the food we eat, the viruses we are exposed to, among other circumstances, all directly influence our state of health; and should be the key determinants driving any research on the geography of disease. Buttressing this observation was a noteworthy study by NCSV in 2010 that factored climate and geographical variables, population data, disease-control data, pathogen data and human history data into statistical models that attempted to show which factors had stronger correlations to disease.

The "place factor"

The spatial location (the geographic context of places and the connectedness between places) plays a major role in shaping environmental risks as well as many other health effects. As Ruiz noted in 2017, carefully designed geographical investigations of the spatial variation of diseases can provide useful clues on what contributes to disease outcomes and options for disease prevention. The occurrence of diseases in some places but not in others, or the variation of disease rates from place to place, should lead the Medical Geologist and others in disease investigation teams to having a closer look at the characteristics that differentiate those places in providing clues to aetiology (See Section on: "Investigation of disease clusters", this article). The importance of the "place factor" in unravelling DUA is well illustrated in the study of spastic paraparesis in Mozambique by Cliff et al. (1984) (Fig. 2).

PLEASE INSERT FIG. 2 HERE. 
Again too, apart from accounting for the diseases themselves, teams investigating the geographical drivers of disease must take cognisance of the characteristics and dynamics of pathogens, vectors and host populations, the presence of xenobiotic chemicals or other toxic agents (See: Ruiz, 2017). This would lend to a more holistic approach in the aetiological characterisation of enigmatic diseases.

Seasonality/spacio-temporal associations of disease

Seasonal change in the incidence of infectious diseases is a common phenomenon worldwide, particularly in continents having temperate or tropical climates. However, the mechanisms responsible for seasonal disease incidence, and the epidemiological consequences of seasonality are, with only a few exceptions, poorly understood (See: Grassly and Fraser, 2006).

The several mechanistic hypotheses that have been advanced to explain seasonality of various directly transmissible diseases include: human activity, pathogen infectivity, seasonal variability in human immune system function, seasonal variations in vitamin D levels and seasonality of melatonin. The influence of these factors in the seasonal patterns of infectious diseases, and whether or not seasonal immune modulation takes place in humans, have been discussed by Grassly and Fraser (2006); Fisman (2012); Fares (2013); and Payntner (2015).

According to Ruiz (2017), geographical factors of disease are related to the weather and geohydrology of a region, the built and natural environment, and population differences in age and cultural and social habits. Spatial patterns are often linked to temporal factors. Seasonal differences in rainfall and temperature, as well as agricultural activities can affect disease patterns and transmission rates (US NRC, 2001; Ruiz, 2017). Under these circumstances, Ruiz (2017) observed that: "When the number of cases of a disease changes across time periods, spatiotemporal analysis can reveal the direction and speed that the disease has spread, and declining disease rates may indicate the effect of preventative actions or development of immunity." MacGillivray and Kollmann had earlier (2014) noted that though an individual may remain geographically constrained, their environmental exposures may vary dramatically depending on seasonality. However, changing temperature, rainfall, exposure to PTEs, food availability, diet, and exposure to infectious agents may also be compounded or alleviated by local cultural and lifestyle practices.

Sometimes, also, disease occurs only after long exposure and can even be absent in ensuing generations; and prior immunity, nutritional health, and genetic differences can have significant impacts on the spatial patterns of diseases. Given this variety, interdisciplinary effort is vital in research aimed at tackling complex disease problems. Ruiz (2017) attempts a presentation of methodological and theoretical threads across a variety of disease systems that are all related to the geography of diseases.

\section{Climate change and health}

The relationship between climate change and health is becoming increasingly clear (Fig. 3) and current knowledge, well documented. Developments in this area of research can be followed up in a multitude of recent publications, and many scientific journals are devoted exclusively to this subject or have whole sections addressing it. With DUA, specifically, however, the relationship with climate is much less clear and relatively few studies or publications exist on the subject.

\section{PLEASE INSERT FIG. 3 HERE.}

According to WHO (2003; 2018b), climate change affects many of the social and environmental determinants of health - clean air, safe drinking water, sufficient food and secure shelter, and so on (Fig. 3). The US Centers for Disease Control and Prevention (US CDC) have warned that: "Climate change threatens human health and well-being in many ways, including impacts from increased extreme weather events, wildfire, decreased air quality, and illnesses transmitted by food, water, and diseases carriers such as mosquitoes and ticks." (US CDC, 2020).

In recent years, attempts in grappling with the challenges of global climate change have revealed unexpected findings on immune system mediation by toxic trace elements, infectious disease (re)emergence, and the expanding field of epigenetics. These findings have helped us recast the environment as an agent of illness. Reflecting this shift, leading international bodies assessing the science related to climate change, such as the WHO and the Intergovernmental Panel 
on Climate Change (IPCC) [e.g., through its Fifth Assessment Report], respectively, have begun to focus attention on contingent, non-linear, and cross-scalar cause and effect relationships between the environment and human health (WHO, 2011; Smith et al., 2014; IPCC, 2019).

The IPCC Report (Smith et al., 2014) along with several other parallel and subsequent studies on climate change (e.g., Denton et al., 2014; Copeland et al., 2017; Morris et al., 2017; NRC, 2019; Aleuy and Kutz, 2020) has revealed that the possible effects of climate change on health and well-being would be realised via multiple, overlapping, and often unpredictable pathways. As Portier et al. noted earlier (2010), climate related health issues would include increased risks of injury, disease, and death from extreme weather events. Added to these effects are those that are wrought by biophysical systems such as the distribution of disease vectors, water-borne diseases, and air pollution (e.g., Smith et al., 2014).

Predicting the impact of climate change impacts on health and disease is beset by confounding variables, is context dependent, and is fraught with uncertainties regarding the drivers and outcomes of change. In this connection, Rohr et al. (2011) suggest that: "... forecasts of climate-change impacts on disease can be improved by more interdisciplinary collaborations, better linking of data and models, addressing confounding variables and context dependencies, and applying metabolic theory to host-parasite systems with consideration of community-level interactions and functional traits, ...".

The links between climate change and infectious disease (Fig. 3) are manifold but are still not well understood (US NRC, 2001; Garcia-Solache and Casadevall (2010); Wu et al., 2016; Ogden, 2018; Boukerche and Mohammed-Roberts, 2020; Casadevall, 2020; El-Sayed and Kamel, 2020); and according to Hofer (2019), these links are both complex and multifactorial. We do know, however, that as pathogens get attuned to gradually warmer temperatures in the natural world, they become better able to withstand the high temperature inside our body. This concurs well with Boukerche and Mohammed-Roberts observation in 2020, that: "As global temperatures rise, long-term changes in climate and wildlife habitat could have a significant effect on human health and increase the risk of infectious diseases like the coronavirus (COVID-19)." (Fig. 3).

The spectrum of illness during heat waves and heat stress

The increasing frequency, duration and magnitude of heat waves have been noted as one category of extreme temperature events (WHO, 2021). Heat wave or heatwave refers to a period of sustained, abnormally high, surface temperatures relative to those normally expected (Robinson, 2001). This phenomenon is observed worldwide and is associated with climate change (Smoyer-Tomic et al., 2003; WHO, 2021). Human exposure to heat waves can lead to a wide range of physiological impacts such as heat exhaustion, dehydration and heatstroke (Kilbourne, 1999; Ye et al., 2012). Heat waves may be characterised by low humidity, which may precipitate drought, or high humidity, which may amplify the health effects of heat-related stress. Existing health conditions may also be exacerbated, causing premature death and disability.

Heat stress occurs when the body cannot cool down properly through sweating, to maintain a healthy temperature $\left(37^{\circ} \mathrm{C}\right)$. It can take the form of relatively mild conditions such as heat rash and heat cramps to more serious conditions such as heat exhaustion (Li et al., 2020). Some authors have noted that increase in global temperatures wrought by climate change will increase the prevalence of heat stress (WHO, 2018b; Li et al., 2020).

Glaser et al. (2016) have considered the effect of heat stress (resulting from climate change) on the emergent epidemic of chronic kidney disease (CKD) in rural communities. These authors propose that "... heat stress nephropathy (HSN) may be a major cause of CKD, representing an overlooked disease in neglected populations in hot communities."

Geopathic stress

It is now fairly well established that stress is a factor in ill health, as it can affect the body's ability to perform certain functions (Freshwater, 1997). These functions include those that rely on the body's subtle energy system (the etheric body, chakras and meridians) (See "Glossary of Terms" for definitions) and the body's electrical system (brain, heart and muscles), thus delaying healing and recovery.

The original definition of geopathic stress (GS) is: "... the study of Earth energies and their effect on human health." (Dovjak and Kukec, 2019). The word "geopathic" is derived from two Greek words: geo, meaning "of the Earth" and pathos, meaning "suffering" or "disease". Interest in the phenomenon was first generated in Germany back in the 1920s (Freshwater 1997). In the early days of study of geopathic stress, it was noted that very few people were aware of its 
association with specific localities, and how a careful selection of locations for civilisations and sites for construction of structures and dwellings were important in avoiding GS (Dharmadhikari et al., 2011). The rationale for judicious site selection for construction purposes was that certain localities overlay geopathic stress zones (GSZ), defined as: 'places on the surface of the Earth having a natural frequency of Earth's magnetic field, and known to cause health problems.' The term also encompasses other weak electromagnetic fields produced by innate geological features like underground water streams or deposits of coal, oil or gas. Man-made structures such as roads, bridges, railways, electricity, water mains and sewers can also cause disruption in the Earth's electromagnetic field, resulting in geopathic stress.

The spectrum of causes of geopathic stress, however, is still not yet well defined, and Freshwater's 1997 account challenges all professionals in health care who are dedicated to the development of holistic care to "... further their understanding and awareness of this phenomenon."

\section{GEOCHEMICAL VARIABLES AND THE HUMAN IMMUNE SYSTEM}

Numerous geoenvironmental factors can modulate human immunity; and it is necessary to understand their interactions in development of the immune system. Such an understanding enables us to address specific aspects of diseases, such as in unravelling the aetiology of DUA, but also, to identify the strategies needed to change trajectories toward long-term, life-long protection from disease. Here, an attempt is made to amalgamate existing data into a cohesive vision that illustrates how exposure to geoenvironmental variables, more especially, the geochemical-, can leave a lasting impression on the human immune system, and how this impression can either have beneficial or potentially deleterious effects.

\section{Cells of the immune system}

The immune system is a complex network of cells and proteins that finds and attacks infectious agents such as bacteria, viruses and fungi (Nicholson, 2016). The three broad categories of immune system cells are: lymphocytes (T-cells, B-cells and NK cells), which are a type of white blood cells; neutrophils, and monocytes/macrophages. Each cell type has specialised functions. For instance, neutrophils are important in fighting bacteria and fungi, while lymphocytes generally fight viruses. The distribution of metal- and metalloid species within a cell or tissue type, referred to as the metallome, constitutes an important study in the context of DUA.

\section{Principles of infection and immunity}

According to Galask et al. (2008), virtually any organism may behave as a pathogen under the right set of conditions; and therefore, it is more instructive to place organisms along a continuum from lesser to greater virulence, rather than classifying them as either pathogens or nonpathogens. Galask et al. (2008) also contended that: "... among individual human hosts, there is a continuum in the intrinsic ability of each host to resist infection."

As long ago as 1934, Theobald Smith suggested, in what is now, perhaps the most insightful statement of the relationship between microbial virulence and host resistance to infection, that: disease was a function of the number of organisms with which a host is initially infected multiplied by the virulence of the organism. This relationship is considered to accurately reflect the nature of the infectious process today, despite modern changes in the ecology of infections

Smith's equation states:

\section{Number of organisms $X$ Virulence of organisms}
Disease $\quad=$
Host's resistance to infection Equation 1.

One can see from Equation 1 that the result of a host's encounter with an infectious agent, even a proven pathogen, will not necessarily be an infectious disease. However, if the host's immunity becomes lowered for some reason, or if the host becomes overwhelmed by an increasing number of organisms, disease may appear, even with an organism of relatively low virulence. Another noteworthy point about Equation 1, is its practical significance, which contributes to the clinician's knowledge about the role of the individual host in infectious disease (Galask et al., 2008).

Immune system mechanisms

There are numerous mechanisms by which trace elements/metals/metalloids are absorbed, distributed, modified and stored in the body, and subsequently eliminated. Only a very brief look at immune system mechanisms is presented here, and only with reference to its interactions with trace elements, including 
metals and metalloids. Readers interested in further details should consult the many excellent publications on the topic (such as: Failla, 2003; Keen et al., 2004; Plumlee and Ziegler, 2006; Plumlee et al., 2006; Galask et al., 2008; Chaplin, 2010; Winans et al., 2011; Nicholson, 2016; Marshall et al., 2018 and Paludan et al., 2020).

Toll-like receptors (TLRs) which are located either on cell surfaces or within endosomes (See: "Glossary of Terms", this article), are type I integral transmembrane receptors involved in the recognition and conveyance of pathogens (including trace elements/metals/metalloids) to the immune system (ElZayat et al., 2019). Some micronutrients (vitamins and trace elements) may be considered as important TLR regulators, as they have immunomodulatory functions. Vitamins D, B12 and A, Zn, Cu and Fe, for instance, have important roles on innate immune responses (El-Zayat et al., 2019).

Thurnham's 2004 review summarises work on, inter alia, "... interactions between nutrients and genes, the influence of gene polymorphisms on micronutrients, the impact of immune responses on micronutrients and specific interactions of antioxidant micronutrients in disease processes to minimise potential prooxidant damage." Mineral deficiency-induced abnormalities in the immune system are particularly profound when they occur during early development (Keen et al., 2004).

In addition to the effect of trace elements on immune function, several studies have shown that, at certain levels, some of these elements, such as Se can influence the genetics of a viral pathogen. Thus, trace element nutrition influences not only the host response to a pathogen but also the pathogen itself (See e.g., Beck, 1999; Lingamaneni et al., 2015).

Factors that influence the toxicities of substances that encounter the body in bioaccessible form (those that are readily released from Earth materials into the body fluids) include: the exposure route, the dose, the chemical form of the substance at exposure, and the processes that chemically transform the substance during absorption, transport, and metabolism (Plumlee et al., 2006; Finkelman et al., 2018; Hasan, 2020). Sometimes, immanent errors of trace element metabolism occur to produce disease, such as when there are basic defects in the trace element transport mechanism (See e.g., Danks, 1985; Ferreira and Ghal, 2017).

\section{CRITICALITY OF THE 'OPTIMAL RANGE OF INTAKE' AND THE OCCURRENCE OF NUTRIENT TOXICITIES}

Writing on the criticality of the optimal range for the micronutrient elements, Mao et al. (2020), remarked: "The dietary requirement for an essential trace element is an intake level which meets a specified criterion for adequacy and thereby minimises risk of nutrient deficiency or excess. Disturbances in trace element homeostasis may result in the development of pathologic states and diseases."

Many nutrients have an antagonistic relationship to one another, which can mean that when one is too high, it causes the other to become too low; and this could increase one's susceptibility to infectious disease which may be acute or chronic. No pair of elements better exemplify this relationship than Cu and Zn, which is as a result of their complex interactions in metabolic processes. A high intake of Cu may adversely affects the absorption or utilisation of $\mathrm{Zn}$, and vice versa. In other words, when your $\mathrm{Cu}$ to $\mathrm{Zn}$ ratio becomes out of balance, many health problems can occur.

Excesses or deficiencies of trace elements/metals/metalloids and infectious diseases often co-occur and are the result of complex metabolic interactions. Most of our essential nutrient intake is from our diet, though, thankfully, this portion alone is unlikely to bear excessive element intake levels. However, the consumption of fortified foods or supplements can also raise the level of trace elements/metals/metalloids and hence increase the chance of toxicity.

Environmental or occupational exposure to potentially toxic levels of elements/metals/metalloids can induce concentrations that are bioavailable to immune cells, high enough to affect their function. Such an imbalance of the immune system caused by pollutants may play a significant role in the incidence of infectious diseases (See e.g., Erickson et al., 2000; Chaturvedi et al., 2004; Hara et al., 2016). In any case, our bodies have an elaborate system for managing and regulating the amount of key trace elements and limiting or eliminating the PTEs circulating in blood and stored in cells (Osredkar and Sustar, 2011). It is when this system fails to function correctly that metabolic disturbances occur, with abnormal levels and ratios of trace elements/metals/metalloids developing and paving the way for occurrence of infectious disease (See e.g., Danks, 1985; Ferreira and Ghal, 2017). 
The concept of nutritional immunity in the context of host defense against pathogens (Djoko et al., 2015) perceives a role for mechanisms by which a host organism sequesters trace elements/metals/metalloids to limit invading pathogens during infection. Calprotectin, for example, can restrict the acquisition of $\mathrm{Zn}$ or Mn (Kehl-Fie et al., 2011). The question remains however, as to whether the host is able to exploit the toxic properties of transition metal ions and use them as bactericides? (See Djoko et al., 2015).

Immunotoxicity due to metals

According to Nriagu and Skaar (2015): "Many parts of the world in which common infectious diseases are endemic also have the highest prevalence of trace metal deficiencies or rising rates of trace metal pollution. Infectious diseases can increase human susceptibility to adverse effects of metal exposure (at suboptimal or toxic levels), and metal excess or deficiency can increase the incidence or severity of infectious diseases."

Metals and metalloids influence the function of immunocompetent cells by a variety of mechanisms. Several of these metals and metalloids are known to be immunotoxic, including: Al, As, Be, Cd, Co, Cr, Cu, Fe, Hg, Mg, Mn, Ni, Pb, Se, Sn, Va and Zn. Depending on the particular metal, its speciation, concentration and bioavailability, and a number of other interdependent factors, a continuous metal/metalloid exposure will result in an immunosuppression or immunoenhancement effect (Kakuschke and Prange (2007).

Immunotoxicity occurs: "... either direct action of the free metal on the cell membrane or other organs of immunocytic components or by catalysis or inhibition of numerous enzyme reactions that are essential to cellular metabolism" (Cabassi, 2007). These interactions interfere with expression of the immune response. In this connection, Cabassi (2007) notes that: "... certain metals at a low exposure concentration manifest immunopotentiating effects, while at high concentrations they cause immunosuppression." Theron et al. (2012) affirmed this observation and went on to point out that it held true particularly for toxic metals such as $\mathrm{Cd}, \mathrm{Hg}$ and $\mathrm{Pb}$, due to their cytotoxic effects which induce apoptosis and/or necrosis of immune cells with consequential weakening of the immune defences to infection.

Cabassi (2007) describes some of the immunosuppression effects earlier identified by Descotes (1999) that xenobiotics (including trace elements/metals/metalloids) can produce. Effects described include: "... changes in leucocyte cellularity, lymphocyte sub-population, reduced resistance of the organism to immune specific alterations, immunosuppression with increased susceptibility to infection and tumour development, immunostimulation with hypersensibility and development of autoimmune diseases." (See Fig. 4).

As Wang et al. stated in 2020, in any discussion on the role of the 'metallome' in the aetiology of dementias of unknown aetiology (cf., Alzheimer's Disease and Parkinson's Disease), "The homeostasis of metal ions is critical for the physiological functions of the brain. In AD (Alzhheimer's Disease) patients or the animal models, the imbalanced metal ions and their transporters have been widely observed. The deposition of metal ions in different brain regions impairs mitochondrial functions and thus causes oxidative stress, which can result in cascade pathological reactions." [Sic]

\section{PLEASE INSERT FIG. 4 HERE.}

\section{Autoimmune diseases}

Autoimmune diseases (ADs) are a heterogeneous group of chronic conditions that affect specific target organs or multiple organ systems. Among the different environmental factors that are known to influence the development of ADs are: infections, low vitamin D levels, UV radiation, and melatonin (Smith and Germolec, 1999; Watad et al. (2017), which factors are also known to exhibit seasonal variation patterns that could influence disease development, severity and progression. Autoimmune disorders may cause destruction of body tissues, abnormal organ development, or changes in organ function.

In 2004, Descotes recapitulated on the importance of autoimmunity as an important area of immunotoxicology, especially because autoimmune diseases are frequent diseases in the general population, and some experimental data suggest a possible link between chemical exposures and autoimmunity.

Many questions remain as to how pathogenic challenge, for instance, may interfere with immune system regulation and give rise to autoimmunity; and it is likely that other apparently novel immune modulatory mechanisms (e.g., trace element/metal interaction) also contribute to clinical ADs (Fig. 4). But, till quite recently, the exact etiopathogenesis of ADs is still not well-defined (See: Getts et al., 2020). 
Dopico et al. (2015) give, as an example of evolutionary adaption of humans to different environments, the loss of skin pigmentation as humans migrated out of Africa to more temperate and colder zones to increase sunlight-driven vitamin D production. Despite such observations, however, the mechanisms by which seasons might more broadly influence the underlying molecular details of human physiology remains unknown (See e.g., Nelson, 2004). Watad et al. (2017) discuss further the effects of seasonality on the onset, relapses and activity of various ADs.

Effect of sunlight on the incidence of autoimmune diseases

Sunlight, the radiation and heat from the sun [ultraviolet radiation (UVR)], is an essential source of light and warmth for all living organisms. It can however have a number of undesirable effects on the health of man "... such as promoting the malignant transformation of skin cells and suppressing the ability of the human immune system to efficiently detect and attack malignant cells.” (Gonzalez Maglio et al., 2016).

However, consideration of seasonal influences on both disease incidence and clinical course as well as recent analytical studies at the individual level have lent support for a possible protective role for UVR in certain diseases (See e.g., Moozhipurath et al., 2020, in relation to the novel corona virus). But Ponsonby et al. (2002) had earlier noted that the available data upon which such notion is made are largely inconclusive.

González Maglio et al. (2016) have put forward some ideas in perspective and have posed some questions within the field of photoimmunology based on established and new information. These authors presume that their ideas may lead to new experimental approaches and hence, to a better understanding of the effects of sunlight on the human immune system.

\section{DISEASE CLUSTERS}

The term cluster (as used in epidemiology) has been defined in various ways (See e.g., Last, 1988; US CDC, 1990; Antó and Cullinan, 2001; Porta, 2008; Dolk et al., 2015; PHE 2019). Taken together, these definitions incorporate the following features: (i) An unusually large aggregation, real or perceived, of events or diseases, over and above the number that could be expected by chance; (ii) The events or diseases are grouped together in time and space (i.e., a particular geographical location, the place of residence, or the location used for a common activity, e.g., workplace). The definition of Porta et al. 2008 singly encapsulates all of these features, i.e.: "Aggregations of relatively uncommon events or diseases in space and/or time in amounts that are believed or perceived to be greater than could be expected by chance. Putative disease clusters are often perceived to exist on the basis of anecdotal evidence, and much effort may be expended by epidemiologists and biostatisticians in assessing whether a true cluster of disease exists."

Recognition of a cluster depends on its size; being reckoned to be greater than would be expected by the play of chance. According to Kumar et al., 2004), 'clustering' may provide clues about the underlying aetiology of a disease (cf., DUA), though this may have initially been based on anecdotal evidence. It is therefore incumbent

on epidemiologists and biostatisticians to assess whether or not the suspected cluster corresponds to an actual increase of disease in the area (See e.g., Song and Kulldorff, 2003). Usually, when clusters are recognised, they are reported to public health authorities in the local area, who may then re-evaluated them as outbreaks, if they (the clusters) are of sufficient size and importance. John Snow's pioneering investigation of the 1854 cholera outbreak in Soho, London (Tulchinsky, 2018), is considered as a classic example of the study of 'disease clusters'.

\section{Investigating disease clusters}

Whenever disease clusters are identified and reported to local or public health authorities by concerned citizens or health care professionals, a response team is usually set up and sent immediately to investigate the cluster. Such an investigation follows a well-established process based on national, regional or international guidance.

What is the value of investigating disease clusters? 
There is hardly any doubt regarding the desirability for disease cluster investigations (including those that are potentially related to environmental or occupational exposures) to be conducted, and for the outcomes of these investigations to be transmitted to relevant public health authorities. There are many inherent gains in performance of a good cluster investigation, but also challenges, too.

The investigation starts with the determination of whether a suspected cluster is a true cluster or not (See, e.g., Kulldorff and Nagarwalla, 1995; Gómez-Rubio et al., 2005; Mclafferty, 2015). Epidemiologists then go on to identify the appropriate scientific approach and organise a data collection plan that synthesises the available health data in the cluster domain. In this way, the identification of clusters and small outbreaks may eventually lead to the isolation of relevant risk factors and provide clues about the underlying aetiology (cf., DUA).

Despite early views that there is little scientific value in cluster investigations e.g., Rothman (1990), there are several researchers who today, contend that 'clusters' should be looked upon solely from their scientific merit.

\section{Multimorbidity disease clusters}

The term disease clusters is often used in another sense, differing from that described in the foregoing sections. Multimorbidity refers to the (co-)occurrence of two or more medical conditions simultaneously in an individual, although some health care professionals sometimes use the more intuitive term " multiple health conditions" (See: Aiden, 2018). Morbidities that cluster together are referred to as concordant multimorbidities, since they can share a common aetiology. Conditions such as: depression, cardiometabolic disorders, cerebrovascular disease and musculoskeletal disorders are most commonly present within multimorbidity clusters (Willadsen et al., 2016).

Co-occurrences of cases often come up in cluster research and are frequently reported as potential clusters. Various environmental exposures, such as can occur in the community or in the workplace, are frequently reported as sources of potential clusters. However, not all co-occurrences of disease cases are clusters perse (Aiden, 2018). Preliminary analytical work, if performed systematically, can often resolve the question of whether a true cluster exists, or not. This may involve comprehensive epidemiological and statistical measurements and thorough assessment of the exposure characteristics to confirm whether a true cluster exists.

According to the UK 'Research and Innovation/National Institute for Health' Research Project Working Group, multimorbidity has received limited scientific attention to date (2020), having previously been regarded as a random assortment of diseases; and hence, difficult to address (UKRI/NIHR, 2020). The call for more research on multimorbidity is justified by the knowledge that the proportion of patients who have two or more medical conditions simultaneously is rising steadily in all age groups in Africa and worldwide (Osakunor et al., 2018; Whitty et al., 2020). Such research would need the application of new multidisciplinary approaches to mapping and tackling these conditions at scale (UKRI/NIHR, 2020). This kind of research was proposed and sponsored by UKRI/NIHR in 2019 (See: UKRI/NIHR, 2020).

Finally, writing on the modus operadi of effectively tackling 'multimorbidity', Whitty et al. (2020) contend that "Clustering of diseases, and how we might better tackle management of coexisting physical and mental health problems, should be embedded into medical training and continuous professional development, including for specialists ..."

\section{Clusters of diseases of unknown aetiology}

In 2016, Rodo et al. reviewed the relevance of environmental factors to health outcomes of ailments whose causes are still poorly understood; and listed several examples of emerging diseases belonging to this cartegory, and surprisingly sharing some common epidemiological features, "... such as their appearance in 'clusters' (grouped geographically; and temporarily progress in nonrandom sequences that repeat every year in a similar way). They also show concurrent trend changes within regions in countries and among different world regions.)" Rodo et als.' (2016) list included: rheumatic diseases such as vasculitides, some inflammatory diseases, or even severe childhood acquired heart diseases, Kawasaki disease (KD), Henoch-Schönlein purpura, Takayasu's aortitis, and ANCA-associated vasculitis. 
In Africa, clusters of DUA do occur occasionally in various geographical localities (e.g., See: Darikwa and Manda, 2020). However, there hardly exists the requisite framework in many African countries for undertaking disease cluster investigations that might contribute towards unravelling the underlying causes of DUA.

\section{Assessment of disease clusters}

In recent years, there has been considerable progress in the use of modern methods for the assessment of clusters. The magnitude of such development has resulted in the recognition of epidemiological and statistical analysis of clusters as a specialised field that has found a place in several journals. Some of the more recent cluster assessments reports are given in: Gómez-Rubio et al. (2005); Coory and Jordan (2013); Forouzanfar et al. (2016); Kronenfeld and Wong (2017) and Stanaway et al. in 2018).

One of the largest and most comprehensive studies of disease clusters known so far was undertaken by the Natural Resources Defense Council (NRDC) and the National Disease Clusters Alliance (NDCA) of the US using information from federal, state and local officials (Navarro et al., 2011). Forty-two disease clusters were found in 13 US states. These institutions subsequently urged federal coordination in order to better investigate these clusters, determine their causes, and work to protect residents in the affected areas.

\section{THE VALUE OF ENVIRONMENTAL RISK MAPS}

According to Lahr and Kooistra (2010), "Risk maps help risk analysts and scientists to explore the spatial nature of the effects of environmental stressors such as pollutants." Environmental risk maps are used as a means for conveying the results of complex environmental risk assessments to public health authorities, policy makers, urban planners, and other stakeholders such as the general public.

In 2014, Pinto et al. wrote: "Geochemical mapping is the base knowledge to identify the regions of the planet with critical contents of potentially toxic elements from either natural or anthropogenic sources. Sediments, soils and waters are the vehicles which link the inorganic environment to life through the supply of essential macro and micro nutrients. The chemical composition of surface geological materials may cause metabolic changes which may favor the occurrence of endemic diseases in humans." [Sic].

In the above context, it is possible to suggest that, for us to create a better understanding of the relationship between surficial geochemistry and public health it is necessary, first, to construct complete geochemical maps at appropriate scales across national boundaries, depicting the surficial distribution of all nongaseous chemical elements (See: Darnley et al., 1995). Such maps have already been drawn for China [(See: Wang et al., 2007; Xie et al., 2008; Cheng et al., 2014), England and Wales (See: Rawlins et al., 2012), Australia (See Reimann and de Caritat, 2017) the USA (See: Smith et al., 2019), and a few other countries]. An overlay of epidemiological maps (of disease distribution) on these geochemical maps would make possible the depiction of areas where disease clusters overlie anomalous element distribution (in water or soil), and so permit an evidence-based statistical assessment of the magnitude of any geochemical component in the disease causative web.

\section{Conclusions}

1. There is currently an increasing worldwide trend in environmental geochemistry research towards determining the circulation of both nutritional elements and PTEs in the water-soil-food crop nexus, that enters the food chain. The prime motivator of this approach has been the increasing realisation of the significance of the entry - largely through the diet - of varying concentration levels of elements that may be bioavailable for negative interactions in metabolic processes that produce diseases, some of whose diagnoses are still ill-defined (the DUA). It is clear that most DUA's are multifactorial diseases, caused by a complex interplay between genetic factors (polygenic), immunological mediators (trace elements/metals/metalloids) and various environmental factors, none of which factors would cause the disease on its own.

2. The human immune system is complex, with numerous environmental factors modulating it early in life. As such, the system is constantly in a state of flux, trying to adapt to various local constraints and conditions imposed by selective pressures of our environment. This inherent plasticity means that our exposure to different geochemicals and pathogenic organisms can result in undesirable outcomes. 
3. After decades of research on the complexity and developmental trajectory of the foetal-neonatal immune system (See e.g., Amarasekera et al., 2020; Jain, 2020; Scanlon, 2020), we are only just beginning to acquire knowledge and insights on the participation of trace elements/metals/metalloids in the selection, maturation and early activation events of the immune cells. Judicious use of modern analytical tools in cell biology-and molecular genetics research, and array technology, will no doubt hasten our understanding of outcomes in these metabolic processes. The position of the "metallome" in the aetiology of SIDS and that of many other DUA needs urgent research!

4. A functional immune system able to prevent or limit infections of the host, is particularly important for many rural populations where exposure to novel infectious occur frequently. From the abundance of evidence adduced in this article, it is becoming increasingly clear that the amount of trace elements/metals/ metalloids taken up largely through the diet, and its outcome in metabolic processes (leading either to accumulation or to deficiency in human tissues), has a significant control on whether the exerted effects are toxic or beneficial. As we gradually begin to fully understand these processes, food safety regulators will have the important and urgent task of re-considering, harmonising and updating current legislative regimes regarding the concentrations of trace elements/metal/ metalloids in food and in drinking water.

5. In order to promote immune-mediated health for life, we must consider the importance of our exposure to geoenvironmental variables and the dynamics of pathogen invasion in immune programming. To do this, however, we still need to seek knowledge on several aspects of immune system programming that starts in early life, and its influence on the risk of developing various DUA. Such research would generate information needed for articulation of future public health initiatives and for drawing renewed attention to the vulnerability of children in early life.

6. The reasons for differences in host immune responsiveness between human populations are now becoming clearer (See: e.g., Quach et al., 2016; Barreiro and Quintana-Murci, 2020), as a result of our greater understanding of evolutionary theory. Such explanations have major implications for the protection of the organism against pathogens and offer clues that can help explain the reason why some populations are particularly susceptible to diseases such as the novel COVID-19, which is more common among the Western nations than it is in Africa (See also: Onyilagha and Uzonna, 2019 and Alfituri et al., 2020).

7. On the other hand, Bentwich et als.' explanation of the difference in HIV diffusion rates between Africans and western populations, back in 1995, lies in the "... over-activation of the immune system in the African population, owing to the extremely high prevalence of infections, particularly helminthic, in Africa. Such activation shifts the cytokine balance towards a T helper 0/2 (Th0/2)-type response, which makes the host more susceptible to infection with human immunodeficiency virus (HIV) and less able to cope with it."

8. Despite the unprecedented rate of global climate change, links between weather and infectious disease have not received much research attention even in high income countries. Improved knowledge on the linkages between environment and infection risk would help sensitise national authorities, policy makers and other stakeholders on the need for investment in robust public health surveillance systems that are able to detect changing disease burdens. An understanding of the divers effects of climate change on the immune system, coupled with recent results from the emerging science of epigenetics would help unravel the aetiology of DUA, which can never be explained or resolved by isolating independent cause and effect relationships.

9. Determinants of disease emergence and persistence interact in a highly complex way within the environment-ecosystem network. Consequently, modelbased projections, as useful as they may be, are fraught with great uncertainty; and so must be designed in a highly circumspective way.

10. Cluster investigations are an important public health strategy for responding to public concern about possible associations between disease and environmental exposures. A proper investigation of a non-communicable disease cluster may help generate hypotheses that can be tested in another study population and time period. It is submitted that the efficiency of cluster investigation teams would be enhanced by inclusion of Medical Geologists, from whom significant geoenvironmental exposure information can be obtained, as well as for an increased potential for unravelment of environment and disease relationships.

11. Increase in public awareness and concern about environmental exposures will continue to spur the need to follow up on reported clusters of disease. This is an important task that we need to carry out within a customised and systematic framework in the light of glowing publicity and under pressing and stressful circumstances. The overarching need for development of techniques for recognising the grouping of cases of a particular disorder in space and time (disease clusters), is that this may provide clues about the underlying aetiology (cf., DUA). 
12. There is little doubt that GIS technology will continue to find widespread application in cluster investigations for non-infectious diseases registries, and by cluster responders. However, to achieve optimal results, new developments such as including more systematic approaches to cluster investigations, improved accuracy in data acquisition, and consideration of geoenvironmental co-factors in disease incidence, may be necessary.

13. It is suggested that correlation maps featuring complete geochemical databases analogous to what exists for China (See: Wang et al. 2007), England and Wales (See: Rawlins et al. 2012), the USA (See: Smith et al. 2019), and a few other countries, would, among other applications, enable the depiction of areas where disease clusters overlie anomalous element distribution (in water, soil or air), and so permit an evidence-based statistical assessment of the magnitude of any geochemical component in the disease causative web.

14. Finally, it is proffered that further intensive research is warranted on the effects of errors/disturbances in metalloid metabolism to help us better understand the importance of this attribution as co-factors in causation of DUA, particularly the neurodegenerative diseases: Alzheimer's disease, autism, Parkinson's disease, and SIDS.

\section{Glossary Of Terms}

Acute disease/illness is any disease or illness that develops quickly, is intense or severe and lasts a relatively short period of time, or, any condition, e.g., infection, trauma, fracture - with a short (often less than 1 month) clinical course.

Apoptosis refers to an orderly process of cell breakdown that occurs in multicellular organisms.

Bias: In the field of statistics, bias refers to the tendency of a statistic to overestimate or underestimate a parameter.

Calprotectin is a protein biomarker released by a neutrophil when there is inflammation in the gastrointestinal (GI) tract, resulting in an increased level in the stool.

Chakra (pl. chakras), a concept is found in the early traditions of Hinduism, refers to various focal points used in a variety of ancient meditation practices, collectively denominated as Tantra, or the esoteric or inner traditions of Hinduism. [Wikipedia, 2021. https://en.wikipedia.org/wiki/Chakra (accessed 20.01.2021)].

A chronic condition is a human health condition or disease that is persistent or otherwise long-lasting in its effects or a disease that comes with time. The term chronic is often applied when the course of the disease lasts for more than three months.

Communicable diseases are those that can be spread from person to person via an infectious agent, such as bacteria, viruses, fungi or parasites. Noncommunicable diseases (NCDs) are the conditions or diseases which are not caused by transmission of infections like that in communicable diseases.

A confounding factor also called a confounding variable, or confounder is a third variable in a study examining a potential cause-and-effect relationship. A confounding variable is related to both the supposed cause and the supposed effect of the study.

Correlational research is a type of non-experimental research method in which a researcher measures two variables, understands and assesses the statistical relationship between them with no influence from any extraneous variable. "Correlation is not causation" means that just because two things correlate does not necessarily mean that one causes the other.

Endosomes are membrane-bound vesicles, formed via a complex family of processes collectively known as endocytosis, and found in the cytoplasm of virtually every animal cell. 
- The etheric body, ether-body or æther body, is a name given by neo-Theosophy to a vital body or subtle body coined by esoteric philosophers to describe the first or lowest layer in the "human energy field" or aura. It is thought to be in immediate contact with the physical body, to sustain it and connect it with "higher" bodies.

Gametes, also referred to as sex cells, are an organism's reproductive cells.

Homeostasis. In biology, the tendency towards a relatively stable state (equilibrium) - internal, physical, and chemical conditions - maintained in physiological processes while adjusting to changing external conditions. Dyshomeostasis, on the other hand, refers to an imbalance or other breakdown of a homeostasis system.

Infectious diseases are disorders caused by organisms such as bacteria, viruses, fungi or parasites. Many organisms live in and on our bodies. They are normally harmless or even helpful. But under certain conditions, some organisms may cause disease.

The immune system is a series of complex defence mechanisms found in humans and other vertebrates, that helps to combat and destroy pathogenic organisms such as bacteria, fungi, viruses, and parasites. The immune system consists of two types of response mechanisms: (i) An antigen-specific adaptive immune response mechanism, also referred as the acquired immune system, which is composed of specialised, systemic cells and processes that eliminate pathogens by preventing their growth; and (ii) The innate immune system is a collection of cells and proteins that are functionally diverse and that defend against invasion by foreign organisms. An innate immune response mechanism, also called natural, is the set of processes that operate to protect the host from the surrounding environment in

Immunosuppression refers a state of decreased immunity.

Lymphocytes are white blood cells that are also one of the body's main types of immune cells.

- Macrophages are large, specialised cells that detect, engulf and destroy bacteria and other harmful organisms.

Melatonin (sometimes referred to as the sleep hormone) is a natural hormone made by the pineal gland (a pea-sized gland situated just above the middle of the brain). It plays a central role in the body's sleep-wake cycle. With its production rising with evening darkness, it promotes healthy sleep and helps orient our circadian rhythm (natural internal processes that follow a 24-hour cycle).

Meridian (as used in acupuncture and Chinese medicine) refers to each of a set of pathways in the body along which vital energy is said to flow.

Metallome: In biochemistry, the metallome is the distribution of metal ions in a cellular compartment.

Monocytes are the largest type of leukocyte (white blood cells). As a part of the vertebrate innate immune system monocytes also influence the process of adaptive immunity.

Mutations are permanent changes in the DNA sequence, and they are a main cause of diversity among organisms.

Myalgia: Pain in a muscle or group of muscles.

Necrosis refers to the premature death of cells in living tissue when too little blood flows to them as a result of disease or injury.

Neutrophils are a type of white blood cell. Most of the white blood cells that lead the immune system's response are neutrophils.

Neurodegenerative disorders are illnesses that involve the death of certain parts of the brain.

Pathogenesis refers to the way (biological mechanism) in which a disease develops. Pathogenicity is the ability of an agent to cause disease (i.e., to harm the host). 
In genetics, a promoter is a sequence of DNA (deoxyribonucleic acid) to which proteins bind that initiate transcription of a single RNA (ribonucleic acid) from the DNA downstream of it. [Wikipedia, 2021. Promoter (genetics).

https://en.wikipedia.org/wiki/Promoter_(genetics) (accessed 26.01.2021].

Reactive oxygen species (ROS): An unstable molecule that contains oxygen and that easily reacts with other molecules in a cell. ROS are the contributors of oxidative stress which leads to various diseases and disorders.

Shank proteins are multidomain scaffold proteins of the postsynaptic density that connect neurotransmitter receptors, ion channels, and other membrane proteins to various metabolic pathways.

A syndrome is a set of medical signs and symptoms which are correlated with each other and often associated with a particular disease or disorder. [Wikipedia, 2020. Syndrome. https://en.wikipedia.org/wiki/Syndrome (accessed 10.01.2021)].

Toll-like receptors (TLRs) are a class of proteins (receptors) that constitute the first line of defence system against microbes.

A xenobiotic is a chemical substance found within an organism that is not naturally produced or expected to be present within the organism. It can also cover substances that are present in much higher concentrations than are usual." [Wikipedia, 2020. https://en.wikipedia.org/wiki/Xenobiotic (accessed 26.01. 2021)].

\section{Declarations}

\section{Funding and/or competing interests}

Funding provided by the Alexander von Humboldt Foundation during the tenure of a research fellowship at the Technical University of Braunschweig, Germany, assisted with the preparation of this manuscript. The author declares he has no other relevant financial or non-financial interests to declare.

\section{Ethics approval}

No ethical approval was required for this study since no human participants, their data or biological materials were involved. No experimental work involving animals was conducted in this study.

\section{Data availability}

No data pertaining to human tissues were reproduced from articles reviewed in this study, obviating the need for ethical approval.

\section{Author contribution}

All contributions to the manuscript were made by the sole author.

\section{Consent to participate}

The work reported in this manuscript did not involve human subjects, and informed consent to participate was not required. 


\section{Consent to publish}

The work reported in this manuscript did not involve human subjects, and informed consent to publish was not required.

\section{References}

Abu-Rabia, A. (2005). The Evil Eye and Cultural Beliefs among the Bedouin Tribes of the Negev, Middle East. Folklore 116 (3), 241 - 254.

DOI: 10.1080/00155870500282677.

Adani, G., Filippini, T., Michalke, B. \& Vinceti, M. (2020). Selenium and other trace elements in the etiology of Parkinson's Disease: A systematic review and meta-analysis of case-control studies. Neuroepidemiology 54, 1 - 23. DOI: 10.1159/000502357.

ADI (Alzheimer's Disease International) (2019). World Alzheimer Report 2019: Attitudes to dementia. London: Alzheimer's Disease International, London. https://www.alzint.org/u/WorldAlzheimerReport2019-Summary.pdf (accessed 29.01.2021).

Ahmadzai, H., Thomas, P.S. \& Wakefield, D. (2013). Laboratory investigations and immunological testing in sarcoidosis. D0I: $10.5772 / 55294$. https://www.intechopen.com/books/sarcoidosis/laboratory-investigations-and-immunological-testing-in-sarcoidosis (accessed 31.10.2020).

Aiden, H. (2018). Multimorbidity: Understanding the Challenge. A Report for the Richmond Group of Charities. https://richmondgroupofcharities.org.uk/sites/default/files/multimorbidity_-_undertanding_the_challenge.pdf (accessed 05.01.2021).

Al-Ayadhi, L.Y. (2005). Heavy metals and trace elements in hair samples of autistic children in central Saudi Arabia. Neurosciences (Riyadh) 10 (3), 213 218. https://www.meta.org/papers/heavy-metals-and-trace-elements-in-hair-samples/22473261 (accessed 04.09.2021).

Aleuy, O.A. \& Kutz, S. (2020). Adaptations, life-history traits and ecological mechanisms of parasites to survive extremes and environmental unpredictability in the face of climate change. International Journal for Parasitology: Parasites and Wildlife 12, 308 - 317. ISSN 2213-

2244. https://doi.org/10.1016/j.ijppaw.2020.07.006. (http://www.sciencedirect.com/science/article/pii/S2213224420300705) (accessed 19.12.2020).

Alfituri, O., Quintana, J., MacLeod, A., Garside, P., Benson, R., Brewer, J., Mabbott, N., Morrison, L., \& Capewell, P. (2020). To the skin and beyond: The immune response to African trypanosomes as they enter and exit the vertebrate host. Frontiers in Immunology. https://doi.org/10.3389/fimmu.2020.01250 (accessed 18.01.2021).

Ali, M.A., El-Khodery, S.A. \& El-Said, W.E. (2015). Potential risk factors associated with ill-thrift in buffalo calves (Bubalus bubalis) raised at smallholder farms in Egypt. Journal of Advanced Research 6 (4), 601- 607. DOI: 10.1016/j.jare.2014.02.005. Epub 2014 Feb 28.

Al-Khalifa, I.I., Hassan, M.F., AL-Deri, S.M. \& Gorial, F.I. (2016). Determination of some essential and non-essential metals in patients with Fibromyalgia Syndrome (FMS). International Journal of Pharmaceutical Sciences and Research 8 (5), 306 - 311. https://www.semanticscholar.org/paper/Determination-ofSome-Essential-\%26-Non-Essential-in-Al-khalifa-Hassan/e36dd0ac35153e551a9475b1161bc2523d76a785 Abstract, figures, tables, retrieved 06.09.2021; no paper link available).

Almaguer, M., Herrera R. \& Orantes, C.M. (2014). Chronic kidney disease of unknown etiology in agricultural communities. MEDICC Review 16 (2), 9 - 15. DOI: $10.37757 / M R 2014 . V 16 . N 2.3$. 
Amarasekera, M., Prescott, S.L. \& Palmer, D.J. (2020). Nutrition in early life, immune-programming and allergies: The role of epigenetics. Asian Pacific Journal of Allergy and Immunology 31 (3), 175 - 82. file:///C:/Users/Admin/Downloads/1386-2763-1-PB.pdf (accessed 06.09.2021).

Amouian, S., Mohammadian, S., Behnampour, N. \& Tizrou, M. (2013). Trace elements in febrile seizure compared to febrile children admitted to an Academic Hospital in Iran, 2011. Journal of Clinical and Diagnostic Research (JCDR) 7 (10), 2231 - 2233. https://doi.org/10.7860/JCDR/2013/5548.3478.

Andretta, A., Dias Batista, E., Madalozzo Schieferdecker, M.E., Petterly, R.R. Boguszewski, C.L. \& dos Santos Paiva, E. (2019). Relation between magnesium and calcium and parameters of pain, quality of life and depression in women with fibromyalgia. Advances in Rheumatology 59, 55. https://doi.org/10.1186/s42358-019-0095-3 (accessed 21.08.2021).

Animasahun, A.B., Adekunle, M.O., Yejide, K. \& Fadipe, C. (2017). The diagnosis of Kawasaki disease among Nigerian children: A nightmare for the caregivers and the doctors. Journal of Public Health and Emergency 1 (7). http://jphe.amegroups.com/article/view/4063/4906 (accessed 30.08.2020).

Antó, J. \& Cullinan, P. (2001). Clusters, classification and epidemiology of interstitial lung diseases: Concepts, methods and critical reflections. The European Respiratory Journal 18, Supplement 101s-106s. https://erj.ersjournals.com/content/18/32_suppl/101s (accessed 17.11.2020).

Arkema, E.V. \& Cozier, Y.C. (2018). Epidemiology of sarcoidosis: Current findings and future directions. Therapeutic Advances in Chronic Disease, 9 (11), 227 240. https://doi.org/10.1177/2040622318790197 (accessed 06.09.2021).

Awotedu, A.A., George, A.O., Oluboyo, P.O., Alabi, G.O., Onadeko, B.O., Ogunseyinde, O. \& Aghadiuno, P.U. (1987). Sarcoidosis in Africans: 12 cases with histological confirmation from Nigeria. Transactions of the Royal Society of Tropical Medicine and Hygiene 81 (6), 1027 - 1029. DOI: 10.1016/00359203(87)90387-7.

Badoe, E.V., Neequaye, J., Oliver-Commey, J.O., Amoah, J., Osafo, A., Aryee, I. \& Nyarko, M.Y. (2011). Kawasaki disease in Ghana: Case reports from Korle Bu Teaching Hospital. Ghana Medical Journal 45 (1), 38 - 42. DOI: 10.4314/gmj.v45i1.68922.

Bagheri, S., Squitti, R., Haertlé, T., Siotto, M. \& Saboury, A.A. (2018). Role of copper in the onset of Alzheimer's Disease compared to other metals. Frontiers in Aging Neuroscience 9, 446. DOI: 10.3389/fnagi.2017.00446.

Baj, J., Flieger, W., Flieger, M., Forma, A., Sitarz, E., Skórzyńska-Dziduszko, K., Grochowski, C., Maciejewski, R. \& Karakuła-Juchnowicz, H. (2021). Autism spectrum disorder: Trace elements imbalances and the pathogenesis and severity of autistic symptoms. Neuroscience Biobehavioural Reviews $129,117-132$. DOI: 10.1016/j.neubiorev.2021.07.029.

Balasooriya, S., Munasinghe, H., Herath, A.T., Diyabalanage, S., lleperuma, O.A. et al. (2020). Possible links between groundwater geochemistry and chronic kidney disease of unknown etiology (CKDu): An investigation from the Ginnoruwa region in Sri Lanka. Exposure and Health 12, 823 -

834. https://doi.org/10.1007/s12403-019-00340-w (accessed 20.01.2021).

Baratti-Mayer, D., Pittet, B., Montandon, D., Bolivar, I. Bornand, J-E., Hugonnet, S., Jaquinet, A., Schrenzel, J. \& Pittet, D. (2003). Noma: An "infectious" disease of unknown aetiology. The Lancet Infectious Diseases 3 (7), 419 - 431. https://www.thelancet.com/journals/laninf/article/PIIS1473-3099(03)00670-4/fulltext (accessed 06.01.2021).

Barreiro, L.B. \& Quintana-Murci, L. (2020). Evolutionary and population (epi)genetics of immunity to infection. Human Genetics 139,723 732. https://doi.org/10.1007/s00439-020-02167-x (accessed 19.01.2021). 
Beck, M.A. (1999). Trace Minerals, Immune Function, and Viral Evolution. In: M. Beck (Ed.), Military Strategies for Sustainment of Nutrition and Immune Function in the Field, Chapter 16. Committee on Military Nutrition Research, Institute of Medicine. National Academies

Press. http://www.nap.edu/catalog/6450.html (accessed 04.09.201).

Beggs, P.J. \& Bambrick, H.J. (2005). Is the global rise of asthma an early impact of anthropogenic climate change? Environmental Health Perspectives 113 (8), 915 - 919. https://doi.org/10.1289/ehp.7724 (accessed 22.08.2021).

Beghè, D., Garavelli, C., Pastorelli, A.A., Muscarella, M., Saccani, G., Aiello, M., Crisafulli, E., Corradi, M., Stacchini, P., Chetta, A. \& Bertorelli, G. (2017). Sarcoidosis in an Italian province: Prevalence and environmental risk factors. PLoS One. https://doi.org/10.1371/journal.pone.0176859 (accessed 31.10.2020).

Beijer, E., Meek, B., Bossuyt, X., Peters, S., Vermuulen, R.C.H., Kromhout, H. \& Veltkamp, M. (2020). Immunoreactivity to metal and silica associates with sarcoidosis in Dutch patients. Respiratory Research 21, 141 (2020). https://doi.org/10.1186/s12931-020-01409-w (accessed 02.02.2021).

Bentwich, Z., Kalinkovich, A. \& Weisman, Z. (1995). Immune activation is a dominant factor in the pathogenesis of African AIDS. Immunology Today 16 (4), 187 - 191. DOI: 10.1016/0167-5699(95)80119-7.

Berry, R.J. (Ed.) (2007). Environmental Dilemmas: Ethics and decisions. Springer Science and Business Media; 271 p. https://books.google.com.ng/books? id=LYdS- ... (accessed 03.12.2020).

Bhaskaran, D., Chadha, S.S., Sarin, S., Sen, R., Arafah, S. \& Dittrich, S. (2019). Diagnostic tools used in the evaluation of acute febrile illness in South India: A scoping review. BMC Infectious Diseases 19, 970 (2019). https://doi.org/10.1186/s12879-019-4589-8 (accessed 02.02.2021).

Bhatti, K., Bandlamudi, M. \& Lopez-Mattei, J. (Updated 2021). Endomyocardial fibrosis. In: StatPearls (Internet). Treasure Island (FL): StatPearls Publishing. https://www.ncbi.nlm.nih.gov/books/NBK513293/ (accessed 20.08.2021).

Bhigjee, A., Moodley, K. \& Ramkissoon, K. (2007). Multiple sclerosis in KwaZulu Natal, South Africa: An epidemiological and clinical study. Multiple Sclerosis 13 (9), 1095 - 1099. DOI: 10.1177/1352458507079274. https://www.semanticscholar.org/paper/Multiple-sclerosis-in-KwaZulu-Natal\%2C-South-Africa\%3ABhigjee-Moodley/2f98d8a44c3b7d1370c7ab280ac7881cc6e3b63d (accessed 01.02.2021).

Bikbov, B., Purcell, C.A., Levey, A.S. \& Smith, M. (2020). Global, regional, and national burden of chronic kidney disease, 1990 - 2017: A systematic analysis for the Global Burden of Disease Study 2017. The Lancet 395 (10225), 709 - 733. https://www.thelancet.com/article/S0140-6736(20)30045-3/fulltext (accessed 04.09.2021).

Bjørklund G. (2013). The role of zinc and copper in autism spectrum disorders. Acta Neurobiologiae Experimentalis, 73 (2), 225 - 236. https://www.researchgate.net/publication/244479056_The_role_of_zinc_and_copper_in_autism_spectrum_disorders (accessed 04.09.2021).

Bjørklund, G., Dadar, M., Pen, J.J., Chirumbolo, S. \& Aaseth, J. (2019). Chronic fatigue syndrome (CFS): Suggestions for a nutritional treatment in the therapeutic approach. Biomedicine and Pharmacotherapy 109, 1000 - 1007. DOI: 10.1016/j.biopha.2018.10.076. Epub 2018 Nov 5.

Bocca, B., Alimonti, A., Petrucci, F., Violante, N., Sancesario, G., Forte, G. \& Senofonte, O. (2004). Quantification of trace elements by sector field inductively coupled plasma mass spectrometry in urine, serum, blood and cerebrospinal fluid of patients with Parkinson's disease. Spectrochimica Acta Part B: Atomic Spectroscopy 59 (4), 559 - 566. https://doi.org/10.1016/j.sab.2004.02.007 (accessed 04.09.2021).

Page 20/55 
Boukerche, S. \& Mohammed-Roberts, R. (2020). Fighting infectious diseases: The connection to climate change. The World

Bank. https://blogs.worldbank.org/climatechange/fighting-infectious-diseases-connection-climate-change (accessed 26.11.2020).

Bourke, C.A. (2018). Astrocyte dysfunction following molybdenum-associated purine loading could initiate Parkinson's disease with dementia. npj Parkinson's Disease 4, 7. https://doi.org/10.1038/s41531-018-0045-5 (accessed 02.02.2021).

Bredholt, M. \& Frederiksen, J.L. (2016). Zinc in multiple sclerosis: A systematic review and meta-analysis. ASN Neuro 8 (3), 1759091416651511. Published June 9, 2016. DOI:10.1177/1759091416651511.

Britannica (2020). The Causes of Disease. https://www.britannica.com/science/human-disease/The-causes-of-disease (accessed 03.12.2020).

Bundschuh, J., Maity, J.P., Mushtaq, S., Vithanage, M. Seneweera, S., et al. (2017). Medical geology in the framework of the sustainable development goals. Science of the Total Environment 581-582. DOI: 10.1016/Caldero j.scitotenv.2016.11.208.

Cabassi, E. (2007). The Immune System and Exposure to Xenobiotics in Animals. Veterinary Research Communications 31 (Supplement 1 ), 115 - 120. DOI: $10.1007 /$ s11259-007-0074-8.

Caddell, J.L. (1992). Hypothesis: New concepts concerning the pathophysiology of the sudden infant death syndrome due to magnesium deficiency shock. Magnesium Research 5 (3), 165 - 172. https://pubmed.ncbi.nlm.nih.gov/1467153/ (accessed 04.09.2021).

Calderón-Garcidueñas, L. (2021). Alzheimer's Disease and Air Pollution: The Ignored Side of Alzheimer's Research, In: Calderón-Garcidueñas, L. (Ed.), Alzheimer's Disease and Air Pollution, Section 1, Volume 8, pp. 1-1. Series: Advances in Alzheimer's Disease. ISBN: 978-1-64368-158-0 (print).

Cambau, E. \& Drancourt, M. (2014). Steps towards the discovery of Mycobacterium tuberculosis by Robert Koch, 1882. Clinical Microbiology and Infection 20 (3),196 - 201. DOI: 10.1111/1469-0691.12555.

Cao, Y., Li, G., Xue, J., Zhang, G., Gao, S., Huang, Y. \& Zhu, A. (2021). Depression and related factors in patients with Parkinson's Disease at high altitude. Neuropsychiatric Disease \& Treatment 17, 1353 - 1362. https://doi.org/10.2147/NDT.S300596 (accessed 27.08.2021).

Capcha, K.M., Pezo, A.P., Cosentino, C. \& Ramirez, L.E.T. (2018). Presentation of Parkinson's disease in patients originating of different geographical altitudes. Neurology 90 (15), 2.080. https://n.neurology.org/content/90/15_Supplement/P2.080 (accessed 13.09.2020).

Caplin, B., Yang, C-W., Anand, S., Levin, A., Madero, M., Saran, R., et al. (2019). The International Society of Nephrology's International Consortium of Collaborators on Chronic Kidney Disease of Unknown Etiology. Report of the Working Group on Approaches to Population-level Detection Strategies and recommendations for a Minimum Dataset. Kidney International 95 (1), 4 - 10. DOI: 10.1016/j.kint.2018.08.019. [Published correction appears in Kidney International 2019, 95 (4), 997 - 998].

Carlsson, J.A. \& Bayes, H.K. (2020). Acute severe asthma in adults. Medicine 48 (5), 297 - 302. https://doi.org/10.1016/j.mpmed.2020.02.008 (accessed 02.02.2021). 
Carpentier, P.H. (1998). Définition et épidémiologie des acrosyndromes vasculaires [Definition and epidemiology of vascular acrosyndromes]. Revue du Praticien 48 (15), 1641 - 1646. (No paper link available).

Carr, R., Warren, R., Towers, L., Bartholomew, A., Duggal, H.V., Rehman, Y., Harrison, T.G. \& Olowokure, B. (2010). Shropshire Outbreak Investigation Team. Investigating a cluster of Legionnaires' cases: Public health implications. Public Health 124 (6), 326 - 331. DOI: 10.1016/j.puhe.2010.03.001. Epub 2010 May 18.

Casadevall, A. (2020). Climate change brings the specter of new infectious diseases. Journal of Clinical Investigation 130 (2), 553 555. https://www.jci.org/articles/view/135003 (accessed 26.11.2020).

Cecchi, L., D’Amato, G., Ayres, J.G., Galan, C., Forastiere, F., Forsberg, B., Gerritsen, J., Nunes, C., Behrendt, H., Akdis, C., Dahl, R. \& Annesi-Maesano, I. (2010). Projections of the effects of climate change on allergic asthma: The contribution of aerobiology. Allergy 2010 65, 1073 1081. https://onlinelibrary.wiley.com/doi/pdfdirect/10.1111/j.1398-9995.2010.02423.x (accessed 22.08.2021).

Chaplin, D.D. (2010). Overview of the immune response. Journal of Allergy and Clinical Immunology 125 (2 Supplement 2): S3 - 23. DOI: 10.1016/j.jaci.2009.12.980.

Chapman, T.L. (2008). Genetic Heavy Metal Toxicity: Explaining SIDS, Autism, Tourette's, Alzheimer's and Other Epidemics. Universe Publ., 210 pp. ISBN: 9780595601547.

Chaturvedi, U.C., Shrivastava, R. \& Upreti, R. K. (2004). Viral infections and trace elements: A complex interaction. Current Science 87 (11), 1536 1554. https://www.researchgate.net/publication/228859735_Viral_infections_and_trace_elements_Complex_interaction (accessed 04.09.2021).

Cheng, Z., Xie, X., Yao, W., Feng, J., Zhang, Q. \& Fang, J. (2014). Multi-element geochemical mapping in Southern China. Journal of Geochemical Exploration 139 (100), 183 - 192. https://doi.org/10.1016/j.gexplo.2013.06.003 (accessed 07.01.2021).

Cilliers, K. (2021). Trace element alterations in Alzheimer's disease: A review. Clinical Anatomy 34, 766 - 773. https://doi.org/10.1002/ca.23727 (accessed 21.08.2021).

Cliff, J., Martelli, A., Molin, A. \& Rosling, H. (for the Ministry of Health, Mozambique) (1984). Mantakassa: An epidemic of spastic paraparesis associated with chronic cyanide intoxication in a cassava staple area of Mozambique. 1. Epidemiology and clinical and laboratory findings in patients. Ministry of Health, Mozambique. Bulletin of the World Health Organisation, 62 (3), 477 - 484. https://apps.who.int/iris/bitstream/handle/10665/265039/PMC2536310.pdf? sequence=1\&isAllowed=y (accessed 06.09.2021).

Cockwell, P. \& Fisher, L-N (2020). The global burden of chronic kidney disease. The Lancet 395 (10225), 662 - 664.

helancet.com/journals/lancet/article/PIIS0140-6736(19)32977-0/fulltext\#: :text=In\%202017\%2C\%20the\%20global\%20prevalence,1\%20to\%203.5) (accessed 27.08.2020).

Compston, A. \& Coles, A. (2002). Multiple sclerosis. The Lancet 359 (9313): 1221 - 1231. DOI: 10.1016/S0140-6736(02)08220-X.

Compston, A. \& Coles, A. (2008). Multiple sclerosis. The Lancet. 372 (9648): 1502-17. DOI: 10.1016/S0140-6736(08)61620-7.

Constantinidis, J. (1991). The hypothesis of zinc deficiency in the pathogenesis of neurofibrillary tangles. Medical Hypotheses 35 (4), 319 - 323. DOI:

10.1016/0306-9877(91)90277-6. 
Coory, M.D. \& Jordan, S. (2013). Assessment of chance should be removed from protocols for investigating cancer clusters. International Journal of Epidemiology 42 (2), 440 -447. https://doi.org/10.1093/ije/dys205 (accessed 04.09.2021).

Copeland, S.M., Bradford, J.B., Duniway, M.C. \& Schuster, R.M. (2017). Potential human impacts of overlapping land-use and climate in a sensitive dryland: A case study of the Colorado Plateau, USA. Ecosphere 8 (5), 1 - 25. DOI: 10.1002/ecs2.1823.

Crocq, M. (1896). De l’ “acrocyanose”. Semaine Medicale 16, 298. (Page link not available).

Crawshaw, M. \& Caldow, G. (2005). Trace Elements in Beef Cattle. Technical Note, No.: TN 572. ISBN: 0142 7695. file:///D:/SAC-TN572-Trace-elementdisorders-in-beef-cattle.pdf (accessed 30.10.2020).

Crump, J., Morrissey, A.B., Nicholson, W.L., Massung, R.F., Stoddard, R.A., Galloway, R.L., et al. (2013). Etiology of severe non-malaria febrile illness in northern Tanzania: A prospective cohort study. PLoS Neglected Tropical Diseases 7e2324. https://journals.plos.org/plosntds/article?id=10.1371/journal.pntd.0002324 (accessed 04.09.2021).

Culver, D.A., Newman, L.S. \& Kavuru, M.S. (2007). Gene environment interactions in sarcoidosis: challenge and opportunity. Clinical Dermatology 25,267 - 275. DOI: 10.1016/j.clindermatol.2007.03.005.

D’Acremont, V., Kilowoko, M., Kyungu, E., Philipina, S., Sangu, W., Kahama-Maro, J., et al. (2014). Beyond malaria - causes of fever in outpatient Tanzanian children. New England Journal of Medicine 370, 809 - 817. https://pngpaediatricsociety.org/wpcontent/uploads/2018/04/DAcremont-V-Multiple-causes-offever-in-childrens-outpatients-in-Tanzania-NEJM-2014.pdf (accessed 04.09.2021).

D’Amato, M., Molino, A., Calabrese, G., Cecchi L., Annesi-Maesano, I. \& D’Amato, G. (2018). The impact of cold on the respiratory tract and its consequences to respiratory health. Clinical and Translational Allergy 8, 20. DOI: 10.1186/s13601-018-0208-9.

Danks, D.M. (1985). Inborn errors of trace element metabolism. Clinics in Endocrinology and Metabolism, 14 (3), 591 - 615. https://doi.org/10.1016/s0300595x(85)80008-6 (accessed 16.08.2021).

Darikwa, T.B. and Manda, S.O. (2020). Spatial co-clustering of cardiovascular diseases and select risk factors among adults in South Africa. International Journal of Environmental Research and Public Health 17 (10), 3583. DOI: 10.3390/ijerph17103583. https://doi.org/10.3390/ijerph17103583 (accessed 24.01.2021).

Darnley, A.G., Björklund, A., Bølviken, B., Gustavsson, N., Koval, P.V., Plant, J.A., Steenfelt, A., Tauchid, M., Xie, X., Garrett, R.G. \& Hall, G.E.M. (1995). A Global Geochemical Database for Environmental and Resource Management. Final Report of IGCP Project 259. Earth Sciences 19, UNESCO Publishing, Paris, 122 pp.; http://globalgeochemicalbaselines.eu.176-31-41-129.hsservers.gr/datafiles/file/Blue_Book_GGD_IGCP259.pdf.

Das, S. \& Maiti, A. (2013). Acrocyanosis: An overview. Indian Journal of Dermatology 58 (6), 417 - 420. https://doi.org/10.4103/0019-5154.119946 (accessed 24.01.2021).

Davaalkham, D., Nakamura, Y., Baigalmaa, D., Chimedsuren, O., Sumberzul, N., et al. (2011). Kawasaki disease in Mongolia: Results from 2 nationwide retrospective surveys, 1996-2008. Journal of Epidemiology 21 (4), 293 - 298. https://www.ncbi.nlm.nih.gov/pmc/articles/PMC3899422/ (accessed 04.09.2021). 
Deacon, E.L. \& Williams, A.L. (1982). The incidence of the sudden infant death syndrome in relation to climate. International Journal of Biometeorology 26, 207 - 218. https://doi.org/10.1007/BF02184936 (accessed 02.02.2021).

De Benedictis, C.A., Vilella, A. \& Grabrucker, A.M. (2019). The role of trace metals in Alzheimer's Disease. In: Wisniewski, T. (Ed.), Alzheimer's Disease, Chapter 6. Brisbane (AU); Codon Publications. https://www.ncbi.nlm.nih.gov/books/NBK552144/ (accessed 13.09.2020).

Dempers, J.J., Burger, E.H., Du Toit-Prinsloo, L. \& Verster, J. (2018). A South African Perspective. In: J.R. Duncan \& R.W. Byard (Eds.), SIDS - Sudden Infant and Early Childhood Death: The Past, the Present and the Future. Chapter 17, University of Adelaide Press. https://www.ncbi.nlm.nih.gov/books/NBK513389/ (accessed 31.10.2020).

Denton, F., Wilbanks, T.J., Abeysinghe, A.C., Burton, I., Gao, Q., Lemos, M.C., Masui, T., O’Brien, K.L. \& Warner, K. (2014). Climate-resilient pathways: Adaptation, mitigation, and sustainable development. In: Climate Change 2014: Impacts, Adaptation \& Vulnerability. Part A: Global and Sectoral Aspects. Contribution of Working Group II to the Fifth Assessment Report of the Intergovernmental Panel on Climate Change In: Field, C.B., Barros, V.R. Dokken, D.J. Mach, K.J. Mastrandrea, M.D. Bilir, T.E. Chatterjee, M. Ebi, K.L. Estrada, Y.O., Genova, R., Girma, C., Kissel, B., Levy, E.S., MacCracken, A.N., Mastrandrea, S.P.R. and White, L.L. (Eds.). Cambridge University Press, Cambridge, United Kingdom and New York, NY, USA, pp. 1101 -

1131. https://www.ipcc.ch/site/assets/uploads/2018/02/WGIIAR5-Chap20_FINAL.pdf (accessed 06.09.2021).

Denisova, O., Chernogoryuk, G., Baranovskaya, N., Rikhvanov, L., Shefer, N., Chernjavskaya, G., Palchikova, I. \& Kalacheva, T. (2020). Trace elements in the lung tissue affected by Sarcoidosis. Biological Trace Element Research 196 (1), 66 - 73. https://doi.org/10.1007/s12011-019-01915-z (accessed 04.09.2021).

Descotes J. (1999). An introduction to immunotoxicology. Taylor and Francis, London. https://doi.org/10.1201/9781482295221(accessed 04.09.2021).

Descotes, 2004. Definition, history, and scope of immunotoxicology. In: J. Descotes, (Ed.), Immunotoxicology of Drugs and Chemicals: An Experimental and Clinical Approach, Volume 1, Chapter 1, Pages 1 - 18. ISBN 9780444510938. Elsevier.

Dharma-Wardana, M.W., Amarasiri, S.L., Dharmawardene, N. \& Panabokke, C.R. (2015). Chronic kidney disease of unknown aetiology and groundwater ionicity: Study based on Sri Lanka. Environmedntal Geochemistry and Health 37(2), 221 - 231. DOI:10.1007/s10653-014-9641-4.

Dharmadhikari, N.P., Meshram, D.C., Kulkarni, S.D., Kharat, A.G. \& Pimplikar, S.S. (2011). Effect of geopathic stress zone on human body voltage and skin resistance. Journal of Engineering and Technology Research 3 (8), 255 -

263. https://academicjournals.org/article/article1380191665_Dharmadhikari\%20et\%20al.pdf (accessed 10.12.2020).

Djoko, K.Y., Ong, C.L., Walker, M.J. \& McEwan, A.G. (2015). The role of copper and zinc toxicity in innate immune defense against bacterial pathogens. The Journal of Biological Chemistry 290 (31), 18954 - 18961. https://doi.org/10.1074/jbc.R115.647099 (accessed 01.12.2020).

Dolk, H., Loane, M., Teljeur, C., Densem, J., Greenlees, R., McCullough, N., Morris, J., Nelen, V., Bianchi, F. \& Kelly, A. (2015). Detection and investigation of temporal clusters of congenital anomaly in Europe: seven years of experience of the EUROCAT surveillance system. European Journal of Epidemiology 30 (11), 1153 - 1164. https://doi.org/10.1007/s10654-015-0012-y (accessed 29.01.2021).

Donnelly, J. (2012). CDC planning trial for mysterious nodding syndrome. The Lancet 379 (9813) i, 287-384, e20-e26. https://doi.org/10.1016/S01406736(12)60126-3 (accessed 02.02.2021).

Dopico, X.C., Evangelou, M., Ferreira, R.C., Guo, H., Pekalski, M.L., Smyth, D.J., Cooper, N., Burren, O.S., Fulford, A.J., Hennig, B.J., Prentice, A.M., Ziegler, A-G., Bonifacio, E., Wallace, C. \& Todd, J.A. (2015). Widespread seasonal gene expression reveals annual differences in human immunity and physiology. Nature Communications 6, 7000. DOI: 10.1038/ncomms8000. 
Dorsey, E.R. and the 2016 Global Burden of Disease Collaborators (2018). Global, Regional and National Burden of Parkinson's Disease, 1990 - 2016 . The Lancet Neurology 17 (11), 939 - 953. https://www.thelancet.com/journals/laneur/article/PIIS1474-4422(18)30295-3/fulltext\#\%20 (accessed 11.09.2020).

Dovjak, M. and Kukec, A. (2019). Identification of health risk factors and their parameters. In: M. Dovjak \& A. Kukec (Eds.), Creating Healthy and Sustainable Buildings: An Assessment of Health Risk Factors, Chapter 3. Springer Cham (CH). ISBN-13: 978-3-030-19411-6ISBN-13: 978-3-030-19412-

3. https://www.ncbi.nlm.nih.gov/books/NBK553923/ (accessed 05.12.2020).

Dowell, S.F., Sejvar, J.J., Riek, L., Vandemaele, K.A., Lamunu, M., Kuesel, A.C., Schmutzhard, E., Matuja, W., Bunga, S., Foltz, J., Nutman, T.B., Winkler, A.S. \& Mbonye, A.K. (2013). Nodding syndrome. Emerging Infectious Diseases 19(9), 1374 - 1384. https://doi.org/10.3201/eid1909.130401. (accessed 27.01.2021).

Drasch, G.A., Kretschmer, E. \& Lochner, C. (1988). Lead and sudden infant death. European Journal of Paediatrics 147,79 - 84 (1988). https://doi.org/10.1007/BF00442618 (accessed 29.08.2021).

Dummer, T.J. (2008). Health geography: Supporting public health policy and planning. CMAJ: Canadian Medical Association Journal 178 (9), 1177 1180. https://doi.org/10.1503/cmaj.071783 (accessed 02.02.2021).

Duncan, J.R. \& Byard, R.W. (Eds.) (2018). SIDS - Sudden Infant and Early Childhood Death: The Past, the Present and the Future. University of Adelaide Press. 846 p. ISBN-13: 978-1-925261-67-7; ISBN-13: 978-1-925261-68-4.

Eapen, J.T., Kartha, C.C. \& Valiathan, M.S. (1997). Cerium levels are elevated in the serum of patients with endomyocardial fibrosis (EMF). Biology of Trace Element Research 59, 41 - 44. https://doi.org/10.1007/BF02783228 (accessed 20.08.2021).

Ebi, K.L., Hess, J.J. \& Watkiss, P. (2017). Health risks and costs of climate variability and change. In: C.N. Mock, R. Nugent, O. Kobusingye \& K.R. Smith (Eds.), Injury Prevention and Environmental Health. 3rd Edition, Figure 8.1 - Impacts of Climate Change on Human Health. Washington, DC, The International Bank for Reconstruction and Development/The World Bank. @ World Bank. https://www.ncbi.nlm.nih.gov/books/NBK525226/ (accessed 03.11.2021). https://openknowledge.worldbank.org/handle/10986/28576 (accessed 10.11.2021). License: CC BY 3.0 IGO.

Edwards, J.R. \& Prozialeck, W.C. (2009). Cadmium, diabetes and chronic kidney disease. Toxicology and Applied Pharmacology 238, 289 - 93. DOI: 10.1016/j.taap.2009.03.007.

Ehmann, W.D., Markesbery, W.R., Alauddin, M., Hossain, T.I. \& Brubaker, E.H. (1986). Brain trace elements in Alzheimer's disease. Neurotoxicology 7 (1), 195 206. https://pubmed.ncbi.nlm.nih.gov/3393299/ ('Abstract' accessed 06.09.2021).

Elakabawi, K., Lin, J., Jiao, F., Guo, N. \& Yuan, Z. (2020). Kawasaki Disease: Global Burden and Genetic Background. Cardiology Research 11 (1), 9 14. https://cardiologyres.org/index.php/Cardiologyres/article/view/993/1008 (accessed 28.08.2020).

Ellwanger, J.H., Franke, S.I., Bordin, D.L., Prá, D. \& Henriques, J.A. (2016). Biological functions of selenium and its potential influence on Parkinson's disease. Annals of the Brazilian Academy of Sciences 88 (3 Suppl.), 1655 - 1674. DOI: 10.1590/0001-3765201620150595. https://doi.org/10.1590/0001-

3765201620150595 (accessed 22.01.2021).

Elsabbagh, M., Divan, G., Koh, Y. J., Kim, Y. S., Kauchali, S., Marcín, C., Montiel-Nava, C., Patel, V., Paula, C. S., Wang, C., Yasamy, M. T. \& Fombonne, E. (2012). Global prevalence of autism and other pervasive developmental disorders. Autism Research: Official Journal of the International Society for Autism Research 
5(3), 160 - 179. https://doi.org/10.1002/aur.239 (accessed 19.08.2021).

El-Sayed, A. \& Kamel, M. (2020). Climatic changes and their role in emergence and re-emergence of diseases. Environmental Science and Pollution Research 27 (18), 22336 - 22352. https://doi.org/10.1007/s11356-020-08896-w (accessed 19.12.2020).

El-Zayat, S.R., Sibaii, H. \& Mannaa, F.A. (2019). Micronutrients and many important factors that affect the physiological functions of toll-like receptors. Bulletin of the National Research Centre 43, 123. https://doi.org/10.1186/s42269-019-0165-z (accessed 02.02.2021).

EME CFS (Encyclopaedia of Myalgic Encephalomyelitis) (2020). Epidemiology of Myalgic Encephalomyelitis and Chronic Fatigue Syndrome. https://mepedia.org/wiki/Epidemiology_of_myalgic_encephalomyelitis_and_chronic_fatigue_syndrome\#: :text=Statistics\%20on\%20the\%20prevalence\%20of,t (accessed 29.10.2020).

Erickson, M.M., Poklis, A., Gantner, G.E., Dickinson, A.W. \& Hillman, L.S. (1983). Tissue mineral levels in victims of sudden infant death syndrome I. Toxic metals - lead and cadmium. Pediatric Research 17(10), 779 - 84. DOI: 10.1203/00006450-198310000-00002.

Erickson, K.L., Medina, E.A. \& Hubbard, N.E. (2000). Micronutrients and innate immunity. Journal of Infectious Diseases 182 (Supplement 1 ), 5 - 10. DOI:10.1086/315922.

Essouma, M., Nkeck, J.R., Endomba, F.T., Bigna, J.J., Singwe-Ngandeu, M. \& Hachulla, E. (2020). Systemic Lupus erythematosus in Native sub-Saharan Africans: A systematic review and meta-analysis. Journal of Autoimmunity 106, 102348. DOI: 10.1016/j.jaut.2019.102348. Epub 2019 Oct 23.

Failla, M.L. (2003). Trace elements and host defense: Recent advances and continuing challenges. The Journal of Nutrition 133 (5), $1443 \mathrm{~S}$

1447S. https://doi.org/10.1093/jn/133.5.1443S (accessed 02.02.2021).

Fares, A. (2013). International Factors influencing the seasonal patterns of infectious diseases Journal of Preventive Medicine 4 (2), 128 - 132. https://www.ncbi.nlm.nih.gov/pmc/articles/PMC3604842/ (accessed 04.09.2021).

Farley, E., Ariti, C., Amirtharajah, M., Kamu, C., Oluyide, B., Shoaib, M., Isah, S., Adetunji, A.S., Saleh, F., Ihekweazu, C., Pereboom, M. \& Sherlock, M. (2021). Noma, a neglected disease: A viewpoint article. PLoS Neglected Tropical Diseases 15 (6), e0009437. https://doi.org/10.1371/journal.pntd.0009437 (accessed 22.08.2021).

Ferreira, C.R. \& Gahl, W.A. (2017). Disorders of metal metabolism. Translational Science of Rare Diseases 2 (3 - 4), 101 - 139. https://doi.org/10.3233/TRD170015 (accessed 10.08.2021).

Fiłon, J., Ustymowicz-Farbiszewska, J. \& Krajewska-Kułak, E. (2020). Analysis of lead, arsenic and calcium content in the hair of children with autism spectrum disorder. BMC Public Health 20, 383 (2020). https://doi.org/10.1186/s12889-020-08496-w (accessed 04.09,2021).

Finkelman, R.B., Orem, W.H., Plumlee, G.S. \& Selinus, O. (2018). Applications of geochemistry to medical geology. In: B. De Vivo, H.E. Belkin \& A. Lima (Eds.), Environmental Geochemistry: Site Characterization, Data Analysis and Case Histories, 2nd Edition; Chapter 17, p. 435 - 465. D0I: 10.1016/B978-0-444-637635.00018-5. Elsevier.

Fisman, D. (2012). Seasonality of viral infections: Mechanisms and unknowns. Clinical Microbiology and Infection 18 (10), 946 954. https://doi.org/10.1111/j.1469-0691.2012.03968.x (accessed 02.02.2021). ISSN 1198-743X.

Page 26/55 
Floris, M., Lepori, N., Angioi, A., Cabiddu, G., Piras, D., Loi, V., Swaminathan, S, Rosner, M.H. \& Pani, A. (2021). Chronic kidney disease of undetermined etiology around the world. Kidney Blood Press Research 46, 142 - 151. DOI: 10.1159/000513014.

Foltz, J.L., Makumbi, I., Sejvar, J.J., Malimbo, M., Ndyomugyenyi, R., Atai-Omoruto, A.D., Alexander, L.N., Abang, B., Melstrom, P., Kakooza, A.M., Olara, D., Downing, R.G., Nutman, T.B., Dowell, S.F. \& Lwamafa, D.K. (2013). An Epidemiologic investigation of potential risk factors for Nodding Syndrome in Kitgum District, Uganda. PloS One 8 (6), e66419. https://doi.org/10.1371/journal.pone.0066419 (accessed 22.08.2021).

Forouzanfar, M.H., Afshin, A., Alexander, L.T., Anderson, Bhutta, Z.A. et al. (GBD Risk Factors Collaborators) (2016). Global, regional, and national comparative risk assessment of 79 behavioural, environmental and occupational, and metabolic risks or clusters of risks, 1990 - 2015: A systematic analysis for the Global Burden of Disease Study 2015. The Lancet 388 (10053), 1659 - 1724. DOI: 10.1016/S0140-6736(16)31679-8.

Fors, E.A. \& Sexton, H. (2002). Weather and the pain in fibromyalgia: are they related? Annals of the Rheumatic Diseases 61, 247 - 250. https://ard.bmj.com/content/61/3/247 (accessed 21.08.2021).

Forte, G., Bocca, B., Senofonte, O., Petrucci, F., Brusa, L., Stanzione, P. et al. (2004). Trace and major elements in whole blood, serum, cerebrospinal fluid and urine of patients with Parkinson's disease. Journal of Neural Transmission (Vienna) 111 (8), 1031-1040. D0I:10.1007/s00702-004-0124-0.

Freshwater, D. (1997). Geopathic stress. Complement Ther Nurs Midwifery 3 (6), 160 - 162. DOI: 10.1016/s1353-6117(05)81003-0.

Galask, R., Larsen, B. \& Ohm, M.J. (2008). Infection in Maternal-Fetal Medicine: An Overview. Welfare of Women, Global Health Programme. Global Library of Women's Medicine. ISSN: 1756-2228. DOI 10.3843/GLOWM.10173. https://www.glowm.com/section-view/heading/infection-in-maternal-fetal-medicine-anoverview/item/173\#.YTNRPp0zY2w (accessed 04.09.2021).

Ganeshan, D., Menias, C.O., Luber, M.G., Pickhardt, P.J., Sandrasegaran, K. \& Bhalla, S. (2018). Sarcoidosis from head to toe: What the Radiologist Needs to Know. Radiographics 38 (4), 1180 - 1200. DOI: 10.1148/rg.2018170157.

Garchitorena, A., Sokolow, S.H., Roche, B., Ngonghala, C.N., Jocque, M., Lund, A., Barry, M., Mordecai, E.A., et al. (2017). Disease ecology, health and the environment: A framework to account for ecological and socio-economic drivers in the control of neglected tropical diseases. Philosophical Transactions of the Royal Society, Section B: 37220160128. http://doi.org/10.1098/rstb.2016.0128 (accessed 02.02.2021).

Garcia-Solache, M.A. \& Casadevall, A. (2010). Global warming will bring new fungal diseases for mammals. mBio (American Society for Microbiology) 1 (1), e00061 - 10. https://doi.org/10.1128/mBio.00061-10 (accessed 02.02.2021).

Gellein, K., Syversen, T., Steinnes, E., Nilsen, T.I.L, Dahl, O.P., Mitrovic, S., Duraj, D. \& Flatten, T.P., 2008. Trace elements in serum from patients with Parkinson's disease - A prospective case-control study: The Nord-Trøndelag Health Study (HUNT). Brain Research 1219, 111 - 115. DOI: 10.1016/j.brainres.2008.05.002.

George, M., Wiklund, L., Aastrup, M., Pousette, J., Thunholm, B., Saldeen, T., Wernroth, L., Zarén, B. \& Holmberg, L. (2001). Incidence and geographical distribution of sudden infant death syndrome in relation to content of nitrate in drinking water and groundwater levels. European Journal of Clinical Investigations 31 (12), 1083 - 1094. DOI: 10.1046/j.1365-2362.2001.00921.x. PMID: 11903496.

Getts, D.R., Spiteri, A., King, N.J.C. \& Miller, S.D. (2020). Microbial infection as a trigger of t-cell autoimmunity. In: N. Rose \& I. Mackay (Eds.), The Autoimmune Diseases, $6^{\text {th }}$ Edition, Chapter 21, pp. 363 - 374. Academic Press. http://www.sciencedirect.com/science/article/pii/B978012812102300021X (accessed 23.12.2020). 
Gifford, F.J., Gifford, R.M, Eddleston, M. \& Dhaun, N. (2017). Endemic nephropathy around the World. Kidney International Reports 2 (2), 282 292. https://doi.org/10.1016/j.ekir.2016.11.003 (accessed 02.02.2021).

Glaser, J., Lemery, J., Rajagopalan, B., Diaz, H. F., García-Trabanino, R., Taduri, G., Madero, M., Amarasinghe, M., Abraham, G., Anutrakulchai, S., Jha, V., Stenvinkel, P., Roncal-Jimenez, C., Lanaspa, M. A., Correa-Rotter, R., Sheikh-Hamad, D., Burdmann, E. A., Andres-Hernando, A., Milagres, T., Weiss, I., ... Johnson, R. J. (2016). Climate change and the emergent epidemic of CKD from heat stress in rural communities: The case for heat stress nephropathy. Clinical Journal of the American Society of Nephrology: CJASN 11 (8), 1472 - 1483. https://doi.org/10.2215/CJN.13841215 (accessed 31.08.2021).

Gobalarajah, K., Prabagar, S., Jayawardena, U., Rasiah, G., Rajendra, S. \& Prabagar, J. (2020). Impact of Water Quality on Chronic Kidney Disease of Unknown Etiology (CKDu) in Thunukkai Division in Mullaitivu District, Sri Lanka. Research Square. DOI: 10.21203/rs.3.rs-19873/v2.

Goenka, A. \& Kollmann, T. (2015). Development of immunity in early life. The Journal of infection 71 (Supplement 1), 112 - 120. DOI: 10.1016/j.jinf.2015.04.027.

Goldwater, P.N. (2017). Infection: The neglected paradigm in SIDS research. Archives of Diseases of Children 102, 767 - 772. DOI:10.1136/archdischild-2016312327

Gómez-Rubio, V., Ferrándiz-Ferragud, J. and López-Quílez, A. (2005). Detecting clusters of disease with R. Journal of Geographical Systems 7, 189 206. https://doi.org/10.1007/s10109-005-0156-5 (accessed 17.11.2020).

González Maglio, D.H., Paz, M.L. and Leoni, J. (2016). Sunlight effects on immune system: Is there something else in addition to UV-induced immunosuppression? Biomedical Research International 1934518. DOI: 10.1155/2016/1934518. Epub 2016 Dec 13.

Grassly, N.C. and Fraser, C. (2006). Seasonal infectious disease epidemiology. Proceedings. Biological sciences 273 (1600), 2541 -

2550. https://doi.org/10.1098/rspb.2006.3604 (accessed 02.02.2021).

Greenough, M.A., Camakaris, J. \& Bush, A.I. (2013). Metal dyshomeostasis and oxidative stress in Alzheimer's disease. Neurochemistry International 62 (5), 540 - 555. https://doi.org/10.1016/j.neuint.2012.08.014 (accessed 21.08.2021).

Grobe, V.J. (1976). Periphere Durchblutungsstörungen und Akrocyanose bei arsengeschädigten Moselwinzern (Peripheral circulatory disorders and acrocyanosis in arsenic exposed Moselle wine-growers). Berufs-Dermatosen 24 (3), 78 - 84.

Guarnieri, M. \& Balmes, J.R. (2014). Outdoor air pollution and asthma. The Lancet 3, 383 (9928), 1581. D0I: 10.1016/S0140-6736(14)60617-6.

GU/WHO [The Government of Uganda (GU)/World Health Organization (WHO)] (2012). Uganda adopts a multi-sectoral response to nodding syndrome. Press Release Kampala, March 2, 2012. Available at: http://reliefweb.int/sites/reliefweb.int/files/resources/kampala-nodding-press-release-02032012.pdf (accessed 25.08.2020).

Ha, H.T.T., Leal-Ortiz, S., Lalwani, K., Kiyonaka, S., Hamachi, I., Mysore, S. P., Montgomery, J.M., Garner, C.C., Huguenard, J.R. \& Kim, S.A. (2018). Shank and zinc mediate an AMPA receptor subunit switch in developing neurons. Frontiers in Molecular Neuroscience 11, 405. https://doi.org/10.3389/fnmol.2018.00405 (accessed 04.09.2021). 
Haase, M. (1923). Etiology unknown. Journal of the American Medical Association 81 (9), 703 - 704. https://doi.org/10.1001/jama.1923.02650090001001 (accessed 19.08.2021).

Habibi, L., Perry, G. \& Mahmoudi, M. (2014). Global warming and neurodegenerative disorders: Speculations on their linkage. Bioimpacts 4 (4), 167 - 170. DOI: 10.15171/bi.2014.013. Epub 2014 Nov 30.

Hara, T., Nakashima, Y., Sakai, Y., Nishio, H., Motomura, Y. \& Yamasaki, S. (2016). Kawasaki disease: a matter of innate immunity. Clinical and Experimental Immunology 186 (2), 134 - 143. https://doi.org/10.1111/cei.12832.

Hasan, S. E. (2020). Medical Geology. Reference Module in Earth Systems and Environmental Sciences, B978-0-12-409548-9.12523-

0. https://doi.org/10.1016/B978-0-12-409548-9.12523-0 (accessed 30.01.2021).

Hedera, P. (2016). Hereditary and Metabolic Myelopathies. Handbook of Clinical Neurolology 136, 769 - 785. D0I: 10.1016/B978-0-444-53486-6.00038-7.

Hedera, P. (Updated 2018). Hereditary Spastic Paraplegia Overview. In: M.P. Adam, H.H. Ardinger, R.A. Pagon, S.E. Wallace, L.J.H. Bean, G. Mirzaa \& A. Amemiya (Eds.), GeneReviews ${ }^{\circledR}$ [Internet]. Seattle (WA), University of Washington, Seattle, 1993 - 2021. https://www.ncbi.nlm.nih.gov/books/NBK1509/ (accessed 30.10.2020).

Hesamian, M.S. \& Eskandari, N. (2020). Potential role of trace elements (Al, Cu, Zn, and Se) in multiple sclerosis physiopathology. Neuroimmunomodulation 27, 163 - 177. DOI: 10.1159/000511308.

Hofer, U. (2019). Candida auris' potential link to climate change. Nature Reviews Microbiology 17, 588. https://doi.org/10.1038/s41579-019-0254-x (accessed 02.02.2021).

Hoffman, K., Weisskopf, M.G., Roberts, A.L., Raz, R., Hart, J.E., Lyall, K., Hoffman, E.M., Laden, F. \& Vieira, V.M. (2017). Geographic Patterns of Autism Spectrum Disorder Among Children of Participants in Nurses' Health Study II. American Journal of Epidemiology 186 (7) 834 - 842. https://doi.org/10.1093/aje/kwx158 (accessed 19.08.2021).

Hu, S.L., Xiong, W., Dai, Z.Q., Zhao, H.L. \& Feng, H. (2016). Cognitive changes during prolonged stay at high altitude and its correlation with C-reactive protein. PLoS One 11 (1), e0146290. https://doi.org/10.1371/journal.pone.0146290 (accessed 27.01.2021).

Hua-Li, Z., Shi-Chao, X., De-Shen, T., Dong, L. \& Hua-Feng, L. (2011). Seasonal distribution of active systemic lupus erythematosus and its correlation with meteorological factors. Clinics (Sao Paulo, Brazil) 66 (6), 1009 - 1013. https://doi.org/10.1590/s1807-59322011000600015 (accessed 17.01.2021).

Hussein, M.M., Yousif, A.A. \& Saeed, A.M. (2008). Serum levels of selenium, zinc, copper and magnesium in asthmatic patients: A case control study. Sudan Journal of Medical Sciences 3 (1), 45 - 48. file:///C:/Users/Admin/Downloads/38512-Article\%20Text-18517-1-10-20081017.pdf (accessed 19.08.2021).

Hyrkäs, H., Ikäheimo, T.M., Jaakkola, J.J. \& Jaakkola, M.S. (2016). Asthma control and cold weather-related respiratory symptoms. Respiratory Medicine 2016 (113), 1 - 7. DOI: 10.1016/j.rmed.2016.02.005.

IPCC (Intergovernmental Panel on Climate Change) (2019). Special Report on the Ocean and Cryosphere in a Changing Climate. https://www.ipcc.ch/srocc/ (accessed 10.01.2021). 
Ismael, M., El-Sayed, M.S., Metwally, A.M. \& Abdullaziz, I.A. (2015). Trace elements status and antioxidants profile in ill-thrift buffalo calves. Alexander Journal of Veterinary Sciences 44 (1), 130 - 135. DOI: 10.5455/ajvs.170301. https://www.alexjvs.com/?mno=170301(accessed 30.10.2020).

Jackson, D.J. \& Johnston, S.L. (2010). The role of viruses in acute exacerbations of asthma. Journal of Allergy and Clinical Immunology 125,1178 - 1187. DOI: 10.1016/j.jaci.2010.04.021.

Jagannatha Rao, K.S., Ranganath Rao, V., Shanmugavelu, P. \& Menon, R.B. [1999 (Last modified 2018)]. Trace elements in Alzheimer's Disease brain: A new hypothesis. In Alzheimer's disease brain: A new hypothesis. Alzheimer's Reports 2 (4), 211 -

216. https://www.researchgate.net/publication/290949066_Trace_elements_in_Alzheimer's_disease_brain_A_new_hypothesis (accessed 05.09.2021).

Jain, N. (2020). The early life education of the immune system: Moms, microbes and (missed) opportunities, Gut Microbes

DOI: 10.1080/19490976.2020.1824564. Gut Microbes 12 (1), 1824564. https://doi.org/10.1080/19490976.2020.1824564 (accessed 20.10.2021).

Janghorbani, M., Shaygannejad, V., Hakimdavood, M. \& Salari, M. (2017). Trace elements in serum samples of patients with multiple sclerosis. Athens Journal of Health 4 (2), 145 - 154. https://www.athensjournals.gr/health/2017-4-2-3-Janghorbani.pdf (accessed 05.09.2021),

Jayasekara, J.M., Dissanayake, D.M., Adhikari, S.B. \& Bandara, P. (2013). Geographical distribution of chronic kidney disease of unknown origin in North Central Region of Sri Lanka. Ceylon Medical Journal 58, 6 - 10. DOI: 10.4038/cmj.v58i1.5356.

Jha, V., Garcia-Garcia, G., Iseki, K., Li, Z., Naicker, S., Plattner, B., Saran. R., et al. (2013). Chronic kidney disease: Global dimension and perspectives. The Lancet 382, 260 - 72. DOI: 10.1016/S0140-6736(13)60687-X. Epub 2013 May 31.

Jhun, I., Mata, D.A., Nordio, F., Lee, M., Schwartz, J. \& Zanobetti, A. (2017). Ambient temperature and sudden infant death syndrome in the United States. Epidemiology 28 (5), 728 - 734. DOI: 10.1097/EDE.0000000000000703.

Johnston, S.L., Pattemore, P.K., Sanderson, G., Smith, S., Lampe, F., Josephs, L., Symington, P., O’Toole, S., Myint, S.H., Tyrrell, D.A.J., et al. (1995). Community study of role of viral infections in exacerbations of asthma in 9 - 11-year-old children. BMJ 310 (6989), 1225 - 1229. DOI: 10.1136/bmj.310.6989.1225.

Judson, M.A. (2020). Environmental Risk Factors for Sarcoidosis. Frontiers in Immunology 11, 1340. DOI:

10.3389/fimmu.2020.01340. https://www.frontiersin.org/article/10.3389/fimmu.2020.01340 (accessed 31.10.2020).

Jung, C.R., Lin, Y.T. \& Hwang, B.F. (2013). Air pollution and newly diagnostic Autism Spectrum Disorders: A population-based cohort study in Taiwan. PLoS One 8 (9), e75510. https://doi.org/10.1371/journal.pone.0075510 (accessed 19.08.2021).

Jung, C.R., Lin, Y.T. \& Hwang, B.F. (2015). Ozone, particulate matter, and newly diagnosed Alzheimer's disease: A population-based cohort study in Taiwan. Journal of Alzheimer's Disease 44 (2), 573 - 584. DOI:10.3233/JAD-140855.

Justiz Vaillant, A.A., Goyal, A. \& Bansal, P. (Updated 2020). Systemic Lupus erythematosus. In: StatPearls [Internet]. Treasure Island (FL): StatPearls Publishing. https://www.ncbi.nlm.nih.gov/books/NBK535405/ (accessed 17.01.2021). 
Kaboré, B., Post, A., Lompo, P., Bognini, J.D., Diallo, S., Kam, B.T.D. et al. (2020). Aetiology of acute febrile illness in children in a high malaria transmission area in West Africa. Clinical Microbiology and Infection (The Official Publication of the European Society of Clinical Microbiology and Infectious Diseases) 57 (4), 590 - 596. DOI: 10.1016/j.cmi.2020.05.029.

Kaiser, C., Benninger, C., Asaba, G., Mugisa, C., Kabagambe, G., Kipp, W. \& Rating, D. (2000). Clinical and electro-clinical classification of epileptic seizure in west Uganda. Bulletin de la Société de Pathologie Exotique 93, 255 - 259. https://pubmed.ncbi.nlm.nih.gov/11204726 (accessed 05.09.2021).

Kakuschke, A. \& Prange, A., 2007. The influence of metal pollution on the immune system: A potential stressor for marine mammals in the North Sea. International Journal of Comparative Psychology 20,179 - 193. https://escholarship.org/uc/item/55p4w9tj (accessed 05.09.2021).

Kaloga, M., Gbéry, I.P., Bamba, V., Kouassi, Y.I., Ecra, E.J., Diabate, A., Kourouma, S., Ahogo, K.C., Kouamé, K.A., Kassi, K., Kouame, K. \& Sangaré, A. (2015). Epidemiological, clinical, and paraclinic aspect of cutaneous sarcoidosis in Black Africans. Dermatology Research and Practice 2015, 802824. DOI: 10.1155/2015/802824. Epub 2015 Nov 8

Keen, C.L., Uriu-Adams, J.Y., Ensunsa, J.L. \& Gershwin, M.E. (2004). Trace elements/minerals and immunity. In: M.E. Gershwin, P. Nestel \& C.L. Keen (Eds.), Handbook of Nutrition and Immunity, pp. 117 - 140. Humana Press, Totowa, NJ. https://doi.org/10.1007/978-1-59259-790-1_6 (accessed 26.12.2020).

Kehl-Fie, T.E., Chitayat, S., Hood, M.I., Damo, S., Restrepo, N., Garcia, C., Munro, K.A., Chazin, W.J. \& Skaar, E.P. (2011). Nutrient metal sequestration by calprotectin inhibits bacterial superoxide defense, enhancing neutrophil killing of Staphylococcus aureus. Cell Host and Microbe 10 (2), 158 -

164. DOI: 10.1016/j.chom.2011.07.004.

Kent, J.T. \& Carr, D. (2020). A visually striking case of primary acrocyanosis: A rare cause of the blue digit. The American Journal of Emergency Medicine 40, 227.e3 - 227.e4. DOI: https://doi.org/10.1016/j.ajem.2020.07.064 (accessed 02.02.2021).

Khalil, S.I. (2020). Endomyocardial fibrosis: Diagnosis and management. Journal of Vascular Diagnostics and Interventions 8,1 -

9. https://doi.org/10.2147/JVD.S196348 (accessed 20.08.2021).

Khayamzadeh, M., Najafi, S., Sadrolodabaei, P., Vakili, F. \& Kharrazi Fard, M.J. (2019). Determining salivary and serum levels of iron, zinc and vitamin B 12 in patients with geographic tongue. Journal of Dental Research, Dental Clinics, Dental Prospects 13 (3), 221 - 226. https://doi.org/10.15171/joddd.2019.034 (accessed 02.02.2021).

Kilbourne, E.M. (1999). The spectrum of illness during heat waves. American Journal of Preventive Medicine 16 (4), 359 - 360. DOI: 10.1016/s07493797(99)00016-1.

Kim, G.B. (2019). Reality of Kawasaki disease epidemiology. Korean Journal Pediatrics 62 (8), 292 - 296. D0I: 10.3345/kjp.2019.00157. Epub 2019 Jul 9.

Kim, Y.S., Kim, K.M., Lee, D.J., Kim, B.T., Park, S.B., Cho, D.Y., et al. (2011). Women with fibromyalgia have lower levels of calcium, magnesium, iron and manganese in hair mineral analysis. Journal of Korean Medical Science 26 (10), 1253 - 1257. DOI: 10.3346/jkms.2011.26.10.1253.

Kister, I., Bacon, T. E., Chamot, E., Salter, A. R., Cutter, G. R., Kalina, J. T. \& Herbert, J., 2013. Natural history of multiple sclerosis symptoms. International Journal of MS Care 15 (3), 146 - 158. https://doi.org/10.7224/1537-2073.2012-053 (accessed 02.02.2021). 
Koester-Hegmann, C., Bengoetxea, H., Kosenkov, D., Thiersch, M., Haider, T., Gassmann, M. \& Schneider, G.E.M. (2019). High-altitude cognitive impairment is prevented by enriched environment including exercise via VEGF signalling. Frontiers in Cellular Neuroscience 12, 532. DOI:10.3389/fncel.2018.00532.

Korevaar, D.A. \& Visser, B.J. (2013). Reviewing the evidence on nodding syndrome, a mysterious tropical disorder. International Journal of Infectious Diseases 17 (3): e149-e152. DOI: 10.1016/j.ijid.2012.09.015.

Kostakou, E., Kaniaris, E., Filiou, E., Vasileiadis, I., Katsaounou, P., Tzortzaki, E., Koulouris, N., Koutsoukou, A. \& Rovina, N. (2019). Acute severe asthma in adolescent and adult patients: Current perspectives on assessment and management. Journal of Clinical Medicine 8 (9), 1283. DOI: 10.3390/JCM8091283.

Kroll-Smith, S., Brown, P.M. \& Gunter, V. (2000). IIIness and the Environment: A Reader in Contested Medicine. ISBN: 9780814747292.464 pp. https://www.thebookstall.com/book/9780814747292 (accessed 30.01.2021).

Kronenfeld, B.J. \& Wong, D.W.S. (2017). Visualizing statistical significance of disease clusters using cartograms. International Journal of Health Geographics 16, 19. https://doi.org/10.1186/s12942-017-0093-9 (accessed 02.02.2021).

Kulldorff, M. \& Nagarwalla, N. (1995). Spatial disease clusters: Detection and inference. Statistics in Medicine 14 (8), 799 810. https://doi.org/10.1002/sim.4780140809 (accessed 31.08.2021).

Kumar, A., Calne, S.M., Schulzer, M., Mak, E., Wszolek, Z., Van Netten, C., Tsui, J.K.C. et al. (2004). Clustering of Parkinson Disease: Shared cause or coincidence? Archives of Neurology 61 (7), 1057 - 1060. DOI:10.1001/archneur.61.7.1057.

Kurklinsky, A.K., Miller, V.M. \& Rooke, T.W. (2011). Acrocyanosis: The Flying Dutchman. Vascular medicine (London, England) 16 (4), 288 301. https://doi.org/10.1177/1358863X11398519.

Lacey, D.C., De Kok, B., Clanchy, F.I., Bailey, M.J., Speed, K., Haynes, D., Graves, S.E. \& Hamilton, J.A. (2009). Low dose metal particles can induce monocyte/macrophage survival. Journal of Orthopaedic Research (The Official Publication of the Orthopaedic Research Society) 27 (11), 1481 1486. https://doi.org/10.1002/jor.20914 (accessed 21.08.2021).

Lahr, J. \& Kooistra, L. (2010). Environmental risk mapping of pollutants: State of the art and communication aspects. Science of the Total Environment 408 (18), 3899 - 3907. DOI: 10.1016/j.scitotenv.2009.10.045. Epub 2009 Nov 24. https://pubmed.ncbi.nlm.nih.gov/19939435/ (accessed 06.01.2021).

Lall, R., Mohammed, R. \& Ojha, U. (2019). What are the links between hypoxia and Alzheimer's Disease? Neuropsychiatric Disease and Treatment 15, 1343 1354. https://www.dovepress.com/what-are-the-links-between-hypoxia-and-alzheimers-disease-peer-reviewed-fulltext-article-NDT\# (accessed 05.09.2021).

Last, J.M. (1988). A Dictionary of Epidemiology. 2nd Ed. New York: Oxford University Press.

Lee, J-H. \& Kim, J.H. (2012). Comparison of serum zinc levels measured by inductively coupled plasma mass spectrometry in preschool children with febrile and afebrile seizures. Annals of Laboratory Medicine 32 (3), 190 - 193. https://doi.org/10.3343/alm.2012.32.3.190 (accessed 11.10.2021).

Lee, B.K., Gross, R., Francis, R.W., Karlsson, H., Schendel, D.E., Sourander, A., Reichenberg, A., Parner, E.T., Hornig, M., Yaniv, A., Leonard, H. \& Sandin, S. (2019). Birth seasonality and risk of autism spectrum disorder. European Journal of Epidemiology 34 (8), 785 - 792. https://doi.org/10.1007/s10654-019-00506-5 (accessed 19.08.2021). 
Lee, H., Aronson, J.F. \& Nunan, D. (2021). Catalogue of Bias. Association or Causation: How do We Ever

Know? https://catalogofbias.org/2019/03/05/association-or-causation-how-do-we-ever-know/ (accessed 10.10,2021).

Lemelle, L., Simionovici, A., Colin, P., Knott, G., Bohic, S., Cloetens, P. \& Schneider, B.L. (2020). Nano-imaging trace elements at organelle levels in substantia nigra overexpressing a-synuclein to model Parkinson's disease. Communications Biology 3, 364. https://doi.org/10.1038/s42003-020-1084-0 (accessed 02.02.2021).

Lepzien, R., Liu, S., Czarnewski, P., Nie, M., Österberg, B., Baharom, F., Pourazar, J., Rankin, G. et al. (2021). Monocytes in sarcoidosis are potent tumour necrosis factor producers and predict disease outcome. European Respiratory Journal 58 (1), 2003468. DOI: 10.1183/13993003.03468-2020.

Li, D., Yuan, J. \& Kopp, R. (2020). Escalating global exposure to compound heat-humidity extremes with warming. Environmental Research Letters 15(6), 064003. DOI: 10.1088/1748-9326/ab7d04.

Li, Y., Jiao, Q., Xu, H., Du, X., Shi, L., Jia, F. \& Jiang, H. (2017). Biometal dyshomeostasis and toxic metal accumulations in the development of Alzheimer's Disease. Frontiers in Molecular Neuroscience 10, 339. https://doi.org/10.3389/fnmol.2017.00339 (accessed 21.08.2021).

Lim, E., Ahn, Y-C., Jang, E-S., Lee, S.W., Lee, S-H. \& Son, C-G. (2020). Systematic review and meta-analysis of the prevalence of chronic fatigue syndrome/myalgic encephalomyelitis (CFS/ME). Journal of Translational Medicine 18, 100. https://translationalmedicine.biomedcentral.com/articles/10.1186/s12967-020-02269-0\#citeas (accessed 29.10.2020).

Lin, M.T. \& Wu, M.H. (2017). The global epidemiology of Kawasaki disease: Review and future perspectives. Global Cardiology Science and Practice 2017 (3), e201720. https://doi.org/10.21542/gcsp.2017.20 (accessed 02.02.2021).

Lingamaneni, P., Kumar, K.K., Teja, C.R., Reddy, B.V.R. \& Krishna, P.L. (2015).

A review on role of essential trace elements in health and disease. Journal of Dr. NTR University of Health Sciences 4 (2), 75 - 85.

https://www.jdrntruhs.org/article.asp?issn=2277-8632;year=2015; volume=4;issue=2;spage=75; epage=85; aulast=Prashanth (accessed 05.09.2021).

Liu, Y., Nguyen, M., Robert, A. \& Meunier, B. (2019). Metal ions in Alzheimer's Disease: A key role or not? Accounts of Chemical Research 52 (7), 2026 - 2035. DOI: $10.1021 /$ acs.accounts.9b00248.

Loef, M. \& Walach, H. (2012). Copper and iron in Alzheimer's disease: A systematic review and its dietary implications. British Journal of Nutrition 107 (1), 7 19. DOI: $10.1017 /$ S000711451100376X.

Lunyera, J., Mohottige, D., Von Isenburg, M., Jeuland, M., Patel, U.D. \& Stanifer, J.W. (2016). CKD of uncertain etiology: A systematic review. Clinical Journal of the American Society of Nephrology (CJASN) 11 (3), 379 - 385. DOI: 10.2215/cjn.07500715.

MacGillivray, D.M. \& Kollmann, T.R. (2014). The role of environmental factors in modulating immune responses in early life. Front Immunology $5,434$. Published online 2014 Sep 12. DOI: 10.3389/fimmu.2014.00434. https://www.frontiersin.org/articles/10.3389/fimmu.2014.00434/full (accessed 25.12.2020).

Mak, O.T. (1988). Prostacyclin production in vascular endothelium of patients with Blackfoot disease. Advances in Experimental Medical Biology 242,119 125. https://doi.org/10.1007/978-1-4684-8935-4_14 (accessed 05.09.2021). 
Manousek, J., Privarova, L. \& Pavkova, G.M. (2014). Metal Hypersensitivity as the Cause of Chronic Fatigue Syndrome: Case Report. In: C. Hudson (Ed.), Chronic Fatigue Syndrome - Risk Factors, Management and Impacts on Daily Life. Neuroscience Research Progress. Nova Science Publishers, New York. 154 p. https://www.researchgate.net/publication/293114653_Metal_Hypersensitivity_As_the_Cause_of_Chronic_Fatigue_Syndrome_Case_Report (accessed 05.09.2021).

Mao, R.J., Moa, A. \& Chughtai, A. (2020). The Epidemiology of Unknown Disease Outbreak Reports Globally. Global Biosecurity 1 (4). DOI: 10.31646/gbio.62. http://doi.org/10.31646/gbio.62 (accessed 30.01.2020).

Marshall, J.S., Warrington, R., Watson, W. \& Kim, H.L. (2018). An introduction to immunology and immunopathology. Allergy Asthma and Clinical Immunology 14, 49. https://doi.org/10.1186/s13223-018-0278-1 (accessed 18.01.2021).

Marques, A.P., Santo, A., Berssaneti, A.A., Matsutani, L.A. \& Yuan, S. (2017). Prevalence of fibromyalgia: Literature review update. Revista Brasileira de Reumatologia 57(4), 356 - 363. https://doi.org/10.1016/j.rbre.2017.01.005 (accessed 21.08.2021).

McCarty, K.M., Hanh, H.T. \& Kim, K.W. (2011). Arsenic geochemistry and human health in South East Asia. Reviews on Environmental Health 26 (1), 71 78. https://doi.org/10.1515/reveh.2011.010 (accessed 02.02.2021).

Mclafferty, S. (2015). Disease cluster detection methods: Recent developments and public health implications, Annals of GIS 21 (2), 127 - 133, DOI: $10.1080 / 19475683.2015 .1008572$

Mehri, A. (2020). Trace Elements in Human Nutrition (II) - An Update. International Journal of Preventive Medicine 11, 2. https://doi.org/10.4103/ijpvm.IJPVM_48_19 (accessed 05.09.2021).

Melø, T.M., Larsen, C., White, L.R., Aasly, J., Sjøbakk, T.E., Flaten, T.P. et al. (2003). Manganese, copper, and zinc in cerebrospinal fluid from patients with multiple sclerosis. Biological Trace Element Research 93, 1 - 8. https://doi.org/10.1385/BTER:93:1-3:1 (accessed 02.02.2021).

Mills, K., Xu, Y., Zhang, W., Bundy, J.D., Chen, C. Kelly, T., Chen, J. \& He, J. (2015). A systematic analysis of world-wide population-based data on the global burden of chronic kidney disease in 2010. Kidney International 88, 950 - 957. https://www.ncbi.nlm.nih.gov/pmc/articles/PMC4653075/ (accessed 05.09.2021).

Mitchell, J. D., East, B. W., Harris, I. A., Prescott, R. J. \& Pentland, B. (1986). Trace elements in the spinal cord and other tissues in motor neuron disease. Journal of Neurology, Neurosurgery and Psychiatry 49 (2), 211 - 215. https://doi.org/10.1136/jnnp.49.2.211 (accessed 30.10.2020).

MLA (Meat and Livestock Australia) (2020). Mineral deficiencies. https://www.mla.com.au/research-and-development/animal-health-welfare-andbiosecurity/diseases/nutritional/mineral-deficiencies (accessed 31.10.2020).

Mocanu, C.S., Jureschi, M. \& Drochioiu, G. (2020). Aluminium binding to modified amyloid- $\beta$ peptides: Implications for Alzheimer's Disease. Molecules (Basel, Switzerland) 25 (19), 4536. DOI: 10.3390/molecules25194536. https://doi.org/10.3390/molecules25194536 (accessed 30.01.2021).

Mocumbi, A.O.H. (2014). Endomyocardial Fibrosis. In: E. Da Cruz, D. Ivy \& J. Jaggers (Eds.), Pediatric and Congenital Cardiology, Cardiac Surgery and Intensive Care. Springer, London. https://doi.org/10.1007/978-1-4471-4619-3_10 (accessed 07.10.2021). 
Mocumbi, A. O., Stothard, J.R., Correia-de-Sá, P. \& Yacoub, M. (2019). Endomyocardial fibrosis: An Update after 70 Years. Current Cardiology Reports 21 (11), 148. DOI: 10.1007/s11886-019-1244-3.

Moozhipurath, R.K., Kraft, L. \& Skiera, B. (2020). Evidence of protective role of ultraviolet-B (UVB) radiation in reducing COVID-19 deaths. Science Reports 10, 17705. https://doi.org/10.1038/s41598-020-74825-z (accessed 17.01.2021).

Morar, R. \& Feldman, C. (2015a). Comorbid illnesses in South African patients with sarcoidosis. European Respiratory Journal 46 (Supplement 59), PA839; DOI: 10.1183/13993003.co9ngress-2015.PA839.

Morar, R. \& Feldman, C. (2015b). Sarcoidosis in Johannesburg, South Africa: A retrospective study. European Respiratory Journal 46 (Supplement 59 ), PA841. DOI: 10.1183/13993003.congress-2015.

Morris, G.P., Reis, S., Beck, S.A., Fleming, L., Adger, W., Benton, T. \& Depledge, M. (2017). Scoping the proximal and distal dimensions of climate change on health and wellbeing. Environmental Health 16, 116. https://doi.org/10.1186/s12940-017-0329-y (accessed 19.12.2020).

MS International Federation (2016). Geographical latitude and the onset of MS

https://www.msif.org/news/2016/12/05/geographical-latitude-and-the-onset-of-ms/ (accessed 31.08.2020).

Murray, E.D., Buttner, E.A. \& Price, B.H. (2012). Depression and Psychosis in Neurological Practice. In: R. Daroff, G. Fenichel, J. Jankovic \& J. Mazziotta (Eds.). Bradley's Neurology in Clinical Practice (6 ${ }^{\text {th }}$ Ed.), pp. 92 - 116. Philadelphia, PA: Elsevier/Saunders. ISBN 978-1-4377-0434-1.

Mutter, J. and Yeter, D. (2008). Kawasaki's disease, acrodynia, and mercury. Current Medical Chemistry 15 (28), 3000 - 3010.

DOI:10.2174/092986708786848712.

Müller-Nordhorn, J., Schneider, A., Grittner, U., Neumann, K., Keil, T., Willich, S.N. \& Binting, S. (2020). International time trends in sudden unexpected infant death, 1969 - 2012. BMC Pediatrics 20,377. https://doi.org/10.1186/s12887-020-02271-x (accessed 02.02.2021)

Nandini, D.B., Bhavana, S.B., Deepak, B.S. \& Ashwini, R. (2016). Paediatric Geographic Tongue: A Case Report, Review and Recent Updates. Journal of Clinical and Diagnostic Research 10 (2), ZE05-9. https://www.ncbi.nlm.nih.gov/pmc/articles/PMC4800664/ (accessed 05.09.2021).

Navarro, K., Janssen, S., Nordbrock, T. \& Gina Solomon, G. (2011). Disease Clusters Spotlight the Need to Protect People from Toxic Chemicals. https://www.nrdc.org/sites/default/files/diseaseclusters_issuepaper.pdf (accessed 23.01.2021).

NCSV (North Carolina State University) (2010). Geography of human disease: Environment has much to do with surrounding pathogens. Science Daily, 15 April 2010. www.sciencedaily.com/releases/2010/04/100415080854.htm (accessed 19.11.2020).

Ndu, I. K. (2016). Sudden infant death syndrome: An unrecognized killer in developing countries. Pediatric health, Medicine and Therapeutics 7, 1 4. https://doi.org/10.2147/PHMT.S99685 (accessed 05.09.2021).

Nelson, R.J. (2004). Seasonal immune function and sickness responses. Trends in Immunology 25 (4), 187 192. http://www.sciencedirect.com/science/article/pii/S1471490604000511 (accessed 23.12.2020).

Page $35 / 55$ 
Newman, L.S. (1998). Metals that cause sarcoidosis. Seminars in Respiratory Infections 13 (3), 212 - 220. europepmc.org/article/MED/9764952 (accessed 05.09.2021).

Nguyen, T., Johnston, S., Clarke, L., Smith, P., Staines, D. \& Marshall-Gradisnik, S. (2017). Impaired calcium mobilization in natural killer cells from chronic fatigue syndrome/myalgic encephalomyelitis patients is associated with transient receptor potential melastatin 3 ion channels. Clinical and Experimental Immunology 187 (2), 284 - 293. DOI: 10.1111/cei.12882. Epub 2016 Nov 23.

Nicholson, L.B. (2016). The immune system. Essays in Biochemistry 60 (3), 275 - 301. https://doi.org/10.1042/EBC20160017 (accessed 25.12.2020).

Njoku, M.G.C., Jason, L.A. \& Torres-Harding, S.R. (2007). The prevalence of chronic fatigue syndrome in Nigeria. Journal of Health Psychology 12 (3), 461 474. https://www.researchgate.net/publication/271585607_The_Prevalence_of_Chronic_Fatigue_Syndrome_in_Nigeria (accessed 05.09.2021).

Noorani, M. \& Lakhani, N. (2018). Kawasaki disease: Two case reports from the Aga Khan Hospital, Dar es Salaam-Tanzania. BMC Pediatrics 18 , 334. https://doi.org/10.1186/s12887-018-1306-5.

NRC (Norwegian Red Cross) (2019). Overlapping vulnerabilities: The impacts of climate change on humanitarian needs. Oslo: Norwegian Red Cross. https://www.rodekors.no/globalassets/globalt/rapporter-program-avtaler/humanitar-analyse-rapporter/norwegian-redcross_report_overlappingvulnerabilities.pdf. (accessed 19.12.2020).

Nriagu, J.O. \& Skaar, E.P. (Eds.). (2015). Trace Metals and Infectious Diseases. ISBN: 9780262029193; 504 pp. https://www.ncbi.nlm.nih.gov/books/NBK569686/ (accessed 05.09.2021).

Nyungura, J.L., Akim, T., Lako, A., Gordon, A., Lejeng, L. \& William, G. (2011). Investigation into the nodding syndrome in Witto Payam, Western Equatoria State, 2010. Southern Sudan Medical Journal 4, 3 - 6. http://www.southsudanmedicaljournal.com/archive/february-2011/investigation-into-the-nodding-syndromein-witto-payam-western-equatoria-state-in-2010.html (accessed 05.09.2021).

Ogbu, C.N. (2003). Sudden infant death syndrome (SIDS) or cot death: A review. West African Journal of Medicine 22 (1).

DOI: 10.4314/wajm.v22i1.27988. https://www.ajol.info/index.php/wajm/article/view/27988 (accessed 31.10.2020).

Ogden, L.E. (2018). Climate change, pathogens, and people: The challenges of monitoring a moving target. BioScience 68 (10) 733 739. https://doi.org/10.1093/biosci/biy101. (accessed 19.12.2020).

Ogueta, C.I., Ramírez, P.M., Jiménez, O.C. \& Cifuentes, M.M. (2019). Geographic Tongue: What a dermatologist should know. Actas Dermo-Sifiliográficas (English Edition) 110 (5), 341 - 346. DOI:10.1016/j.ad.2018.10.022.

Ogunrin, O., Sanya, E., Komolafe, M. \& Osubor, C.C. (2013). Trace metals in patients with Parkinson's Disease: A multi-center case-control study in Nigerian patients. Journal of Neurology and Epidemiology 1, 31 - 38. DOI: 10.12974/2309-6179.2013.01.01.4

Olum, S., Scolding, P., Hardy, C., Obol, J. \& Scolding, N.J. (2020). Nodding syndrome: A concise review. Brain Communications 2 (1), fcaa037. fcaa037. https://doi.org/10.1093/braincomms/fcaa037 (accessed 20.08.2021). 
Onyilagha, C. \& Uzonna, J.E. (2019). Host immune responses and immune evasion strategies in African trypanosomiasis. Frontiers in Immunology 10, 2738. https://www.frontiersin.org/articles/10.3389/fimmu.2019.02738/full (accessed 18.01.2021).

Orlowski, J.P. \& Mercer, R.D. (1980). Urine mercury levels in Kawasaki disease. Pediatrics 66 (4), 633 - 636.

https://pediatrics.aappublications.org/content/66/4/633 (accessed 05.09.2021).

Osakunor, D.N.M., Sengeh, D.M. \& Mutapi, F. (2018). Coinfections and comorbidities in African health systems: At the interface of infectious and noninfectious diseases. PLoS Neglected Tropical Diseases 201812 (9): e0006711. DOI: 10.1371/journal.pntd.0006711.

Osredkar, J. \& Sustar, N. (2011). Copper and zinc, biological role and significance of copper/zinc imbalance. Journal of Clinical Toxicology 2013, S3 (001), 1 19. DOI:10.4172/2161-0495.S3-001. https://www.longdom.org/open-access/copper-and-zinc-biological-role-and-significance-of-copper-zincimbalance-21610495.S3-001.pdf (accessed 07.11.2020).

Pacini, S., Fiore, M.G., Magherini, S., Morucci, G., Branca, J.J., Gulisano, M. \& Ruggiero, M. (2012). Could cadmium be responsible for some of the neurological signs and symptoms of Myalgic Encephalomyelitis/Chronic Fatigue Syndrome. Medical Hypotheses 79 (3), 403 - 407. D0I: 10.1016/j.mehy.2012.06.007. Epub 2012 Jul 12. PMID: 22795611.

Paludan, S.R., Pradeu, T., Masters, S.L. \& Mogensen, T.H. (2020). Constitutive immune mechanisms: mediators of host defence and immune regulation. Nature Reviews Immunology 21, 137 - 150. https://www.nature.com/articles/s41577-020-0391-5\#citeas (accessed 18.01.2021).

Panelli, M.C. (2017). JTM advances in uncharted territories: Diseases and disorders of unknown etiology. Journal of translational medicine 15(1), 192. https://doi.org/10.1186/s12967-017-1293-6 (accessed 02.02.2021).

Patil, P., Jain, H., Mishra, V. \& Sharma, A. (2015). Sarcoidosis: An update for the oral health care provider. Journal of Cranio-Maxillary Diseases 4 (1), 69 - 75. DOI: 10.4103/2278-9588.151908. https://www.researchgate.net/publication/273695005_Sarcoidosis_An_update_for_the_oral_health_care_provider (accessed 02.02.2021).

Paynter, S., Ware, R.S., Sly, P.D., Williams, G. \& Weinstein, P. (2015). Seasonal immune modulation in humans: Observed patterns and potential environmental drivers. Journal of Infection 70 (1), 1 - 10. DOI: 10.1016/j.jinf.2014.09.006. Epub 2014 Sep 22.

Pedro, E.M., da Rosa Franchi Santos, L.F., Scavuzzi, B.M., Iriyoda, T.M.V., Peixe, T.S. \& Lozovoy, M.A.B. (2019). Trace elements associated with systemic Lupus erythematosus and insulin resistance. Biology of Trace Element Research 191 (1), 34 - 44. https://doi.org/10.1007/s12011-018-1592-7 (accessed 17.01.2021).

Perera, B.P.U, Svoboda, L.K. \& Dolinoy, D.C. (2019). Genomic tools for environmental epigenetics and implications for public health. Current Opinion in Toxicology 18, 27 - 33 .

https://doi.org/10.1016/j.cotox.2019.02.008 (accessed 12.12.2020).

PHE (Public Health England) (2019). Guidance for Investigating Non-infectious Disease Clusters from Potential Environmental Causes. https://assets.publishing.service.gov.uk/government/uploads/system/uploads/attachment_data/file/781573/INIDC_guidance_v1.0.pdf (accessed 12.11.2020).

Picciani, B.L., Domingos, T.A., Teixeira-Souza, T., Santos Vde, C., Gonzaga, H.F., Cardoso-Oliveira, J., Gripp, A.C., Dias, E.P. \& Carneiro, S. (2016). Geographic tongue and psoriasis: Clinical, histopathological, immunohistochemical and genetic correlation - A literature review. Brazilian Annals of Dermatology [Anais Brasileiros de Dermatologia (ABD)] 91 (4), 410 - 21. DOI: 10.1590/abd1806-4841.20164288.

Page 37/55 
Picciani, B., Santos, V.C., Teixeira-Souza, T., Izahias, L.M., Curty, Á., Avelleira, J.C., Azulay, D., Pinto, J., Carneiro, S. \& Dias, E. (2017). Investigation of the clinical features of geographic tongue: Unveiling its relationship with oral psoriasis. International Journal of Dermatology 56 (4), 421 - 427. DOI: 10.1111/ijd.13460.

Picciani, B.L.S., Santos, L.R., Teixeira-Souza, T., Dick, T.N.A., Carneiro, S., Pinto, J.M.N. et al. (2020). Geographic tongue severity index: A new and clinical scoring system. Oral Surgery, Oral Medicine, Oral Pathology and Oral Radiology 129 (4), 330 - 338. D0I: 10.1016/j.0000.2019.12.007.

Pietra, R., Edel, J., Sabbioni, E. \& Rizzato, G. Pozzi (1988). Sarcoidosis and trace metals as investigated by neutron activation analysis. International Nuclear Information System (INIS) 19 (23). Excerpta Medica, The Netherlands. https://inis.iaea.org/search/search.aspx?orig_q=RN:19098504 (accessed 05.09.2021).

Pillay, S., Duncan, M. \& de Vries, P.J. (2021). Autism in the Western Cape province of South Africa: Rates, socio-demographics, disability and educational characteristics in one million school children. Autism 25(4), 1076 - 1089. DOI:10.1177/1362361320978042.

Pinto, M.M.S.C., da Silva, E.A.F., Silva, M.M.V.G., Melo-Gonçalves, P. \& Candeias, C. (2014). Environmental risk assessment based on high-resolution spatial maps of potentially toxic elements sampled on stream sediments of Santiago, Cape Verde. Geosciences 4, 297 - 315. DOI: $10.3390 /$ geosciences4040297.

Plumlee, G., Mormon, S.S. \& Ziegler, T.L. (2006). The Toxicological Geochemistry of Earth Materials: An Overview of Processes and the Interdisciplinary Methods Used to Understand Them. In: Sahai, N. and Schoonen, M.A.A. (Ed.): Reviews in Mineralogy and Geochemistry 64, 7. US Geological Survey, Denver. https://doi.org/10.2138/rmg.2006.64.2 (accessed 05.09.2021).

Plumlee, G.S. \& Ziegler, T.L. (2006). The Medical Geochemistry of Dusts, Soils, and Other Earth Materials. In: Sahai, N. and Schoonen, M.A.A. (Ed.): Reviews in Mineralogy and Geochemistry 64, 9. US Geological Survey, Denver. DOI: 10.1016/B0-08-043751-6/09050-2.

Ponsonby, A.L., McMichael, A. \& van der Mei, I. (2002). Ultraviolet radiation and autoimmune disease: insights from epidemiological research. Toxicology 181182, 71- 78. DOI: $10.1016 /$ s0300-483x(02)00257-3.

Porta, M. (Ed.) (2008). A Dictionary of Epidemiology. Oxford University Press, USA. pp. 42 - 43. ISBN 978-0-19-971815-3.

Portier, C., Thigpen-Tart, K., Carter, S., Dilsworth, C., Grambsch, Gohlke, J.M., Hess, J.J. et al. (2010). A Human Health Perspective on Climate Change: A Report Outlining the Research Needs on the Human Health Effects of Climate Change. Environmental Health Perspectives, National Institute of Environmental Health Sciences.

https://www.niehs.nih.gov/health/materials/a_human_health_perspective_on_climate_change_full_report_508.pdf (accessed 20.10.2021).

Portman, M.A., Yeter, D. \& Kuo, H-C. (2018). Ethnic variations in mercury exposure from seafood consumption and the risk of Kawasaki disease in young children. The FASEB Journal (Pathology) 31 (1), 982.5 - 982.5. https://faseb.onlinelibrary.wiley.com/doi/abs/10.1096/fasebj.31.1_supplement.982.5 (accessed 14.09.2020).

Quach, H., Rotival, M., Pothlichet, J., Loh, Y.E., Dannemann, M., Zidane, N., Laval, G., Patin, E., Harmant, C., Lopez, M., Deschamps, M., Naffakh, N., Duffy, D., Coen, A., Leroux-Roels, G., Clément, F., Boland, A., Deleuze, J.F., Kelso, J., Albert, M.L. \& Quintana-Murci, L. (2016). Genetic adaptation and Neandertal admixture shaped the immune system of human populations. Cell 167 (3), 643 - 656. e17. DOI: 10.1016/j.cell.2016.09.024. http://dx.doi.org/10.1016/j.cell.2016.09.024 (accessed 19.01.2021).

Qiu, C., Kivipelto, M. \& von Strauss, E. (2009). Epidemiology of Alzheimer's disease: Occurrence, determinants, and strategies toward intervention. Dialogues in Clinical Neuroscience 11 (2), 111 - 128. DOI: 10.31887/DCNS.2009.11.2/cqiu. https://www.ncbi.nlm.nih.gov/pmc/articles/PMC3181909/ (accessed 
Raj, K., Kaur, P., Gupta, G.D. \& Singh, S. (2021). Metals associated neurodegeneration in Parkinson's disease: Insight to physiological, pathological mechanisms and management. Neuroscience Letters 753, 135873. https://doi.org/10.1016/j.neulet.2021.135873 (accessed 21.08.2021).

Rajapakse, S., Shivanthan, M.C. \& Selvarajah, M. (2016). Chronic kidney disease of unknown etiology in Sri Lanka. International Journal of Occupational and Environmental Health 22 (3), 259 - 264. https://doi.org/10.1080/10773525.2016.1203097 (accessed 02.02.2021).

Ramos-Casals, M., Kostov, B., Brito-Zerón, P., Sisó-Almirall, A. \& Baughman, R.P. (2019). Autoimmune Big Data Study Group. How the frequency and phenotype of Sarcoidosis is driven by environmental determinants. Lung 197(4), 427 - 436. DOI: 10.1007/s00408-019-00243-2. Epub 2019 Jun 12. http://website60s.com/upload/files/lung-v197-iss4-a4.pdf (accessed 01.11.2020).

Rappaport, S.M. (2012). Discovering environmental causes of disease. Journal of Epidemiology and Community Health 66 (2), 99 - 102. D0I: 10.1136/jech2011-200726.

Rappaport, S.M. (2016). Genetic Factors Are Not the Major Causes of Chronic Diseases. PLoS One 11 (4), e0154387. DOI: 10.1371/journal.pone.0154387.

Rawlins, B.G., McGrath, S.P., Scheib, A.J., Breward, N., Cave, M., Lister, T.R., Ingham, M., Gowing, C. \& Carter, S. (2012). The Advanced Soil Geochemical Atlas of England and Wales. (Keyworth, Nottingham: British Geological Survey.) http://ukso.org/static-maps/advanced-soil-geochemical-atlas-of-england-andwales.html\#: :text=The\%20Advanced\%20Soil\%20Geochemical\%20Atlas,National\%20Soil\%20Resources\%20Institute\%2C\%20Cranfield (accessed 27.01.2021).

Redmon, J.H., Elledge, M.F., Womack, D.S., Wickremashinghe, R., Wanigasuriya, K.P., Peiris-John, R.J., Lunyera, J., Smith, K., Raymer, J.H. \& Levine, K.E. (2014). Additional perspectives on chronic kidney disease of unknown aetiology (CKDu) in Sri Lanka - Lessons learned from the WHO CKDu population prevalence study. BMC Nephrology 15(125). https://doi.org/10.1186/1471-2369-15-125 (accessed 26.11.2020).

Rees, F., Doherty, M., Grainge, M.J., Lanyon, P. \& Zhang, W. (2017). The worldwide incidence and prevalence of systemic Lupus erythematosus: A systematic review of epidemiological studies. Rheumatology (Oxford) 56 (11), 1945 - 1961. DOI:

10.1093/rheumatology/kex260. https://pubmed.ncbi.nlm.nih.gov/28968809/ (accessed 17.01.2021).

Reimann, C. \& de Caritat, P. (2017). Establishing geochemical background variation and threshold values for 59 elements in Australian surface soil. Science of The Total Environment 578, 633 - 648. https://doi.org/10.1016/j.scitotenv.2016.11.010 (accessed 05.09.2021).

Richarz, A. \& Brätter, P. (2002). Speciation analysis of trace elements in the brains of individuals with Alzheimer's disease with special emphasis on metallothioneins. Analytical and Bioanalytical Chemistry 372, 412 - 417. https://doi.org/10.1007/s00216-001-1187-5 (accessed 05.09.2021).

Rieder, H.P., Schoettli, G. \& Seiler, H. (1983). Trace elements in whole blood of multiple sclerosis. European Neurology 22 (2), 85 - 92. D0I:10.1159/000115542.

Robinson, P.J., 2001. On the definition of a heat wave. Journal of Applied Meteorology 40 (4), 762 -

775. https://journals.ametsoc.org/view/journals/apme/40/4/1520-0450_2001_040_0762_otdoah_2.0.co_2.xml (accessed 11.01.2021).

Rodo, X., Curcoll, R., Robinson, M., Ballester, J., Burns, J.C., Cayan, D.R., Lipkin, W.I., et al. (2014). Tropospheric winds from northeastern China carry the etiologic agent of Kawasaki disease from its source to Japan. Proceedings of the National Academy of Science of the U.S.A. 111 (22), 7952 - 
7957. DOI: $10.1073 /$ pnas. 1400380111.

Rodo, X., Ballester, J., Curcoll, R. \& Morguí, J. (2016). Revisiting the role of environmental and climate factors on the epidemiology of Kawasaki disease. Annals of the New York Academy of Sciences 1382 (1), 84 - 98. DOI: 10.1111/nyas.13201.

Rohr, J.R., Dobson, A.P., Johnson, P.T., Kilpatrick, A.M., Paull, S.H., Raffel, T.R., Ruiz-Moreno, D. \& Thomas, M.B. (2011). Frontiers in climate change-disease research. Trends in Ecology and Evolution 26 (6), 270 - 277. DOI: 10.1016/j.tree.2011.03.002. Epub 2011 Apr 12.

Rosborg, I., Hyllén, E., Lidbeck, J., Nihlgård, B. \& Gerhardsson, L. (2007). Trace element pattern in patients with fibromyalgia. The Science of the Total Environment 385 (1-3), 20 - 27. https://doi.org/10.1016/j.scitotenv.2007.05.014 (accessed 21.08.2021).

Ross, L.N. (2018). The Doctrine of Specific Etiology. PhilSci Archive 15079. http://philsci-archive.pitt.edu/15079/1/DSE.pdf (accessed 03.12.2020).

Rothman, K.J. (1990). A sobering start for the cluster busters' conference. American Journal of Epidemiology 132 (1 Supplement), 6 - 13. DOI:

10.1093/oxfordjournals.aje.a115790. https://doi.org/10.1093/oxfordjournals.aje.a115790 (accessed 20.10.2021)

Rowell, D., Nghiem, S., Ramagopalan, S. \& Meier, U.C. (2017). Seasonal temperature is associated with Parkinson's disease prescriptions: An ecological study. International Journal of Biometeorology 61 (12), 2205 - 2211. https://doi.org/10.1007/s00484-017-1427-9 (accessed 02.02.2021).

Rouwet, D., Tanyileke, G. \& Costa, A. (2016). Cameroon's Lake Nyos gas burst: 30 Years later. Eos 97. D0I:10.1029/2016eo055627. https://eos.org/meetingreports/cameroons-lake-nyos-gas-burst-30-years-later (accessed 12.12.2020).

Rowley, A.H. \& Shulman, S.T. (2018). The epidemiology and pathogenesis of Kawasaki Disease. Frontiers in Pediatrics 6, 374. D0I: 10.3389/fped.2018.00374. https://www.frontiersin.org/article/10.3389/fped.2018.00374 (accessed 02.02.2021).

Ruiz, M.O. (2017). Geography of Disease. Oxford Bilbliographies. https://www.oxfordbibliographies.com/view/document/obo-9780199874002/obo9780199874002-0153.xml (accessed 20.10.2021.

Russ, T.C., Murianni, L., Icaza, G., Slachevsky, A. \& Starr, J.M. (2016). Geographical variation in dementia mortality in Italy, New Zealand, and Chile: The Impact of latitude, Vitamin D, and air Pollution. Dementia, Geriatric and Cognitive Disorders 42 (1-2), 31 - 41. DOI: 10.1159/000447449.

Rypdal, M., Rypdal, V., Burney, J.A., Cayan, D., Bainto, E., Skochko, S. et al. (2018). Clustering and climate associations of Kawasaki Disease in San Diego County suggest environmental triggers. Scientific Reports 8, 16140. https://doi.org/10.1038/s41598-018-33124-4 (accessed 02.02.2021).

Sabel, C.E., Pearson, J.F., Mason, D.F., Willoughby, E., Abernethy, D.A. \& Taylor, B.V. (2021). The latitude gradient for multiple sclerosis prevalence is established in the early lifecourse. Brain: A Journal of Neurology, awab104. Advance online publication. https://doi.org/10.1093/brain/awab104 (accessed 27.08.2020).

Saghazadeh, A., Ahangari, N., Hendi, K., Saleh, F. \& Rezaei, N. (2017). Status of essential elements in autism spectrum disorder: Systematic review and metaanalysis. Reviews in the Neurosciences 28 (7), 783 - 809. https://doi.org/10.1515/revneuro-2017-0015 (accessed 19.08.2021). 
Sahebari, M., Abrishami-Moghaddam, M., Moezzi, A., Ghayour-Mobarhan, M., Mirfeizi, Z., Esmaily, H. \& Ferns, G. (2014). Association between serum trace element concentrations and the disease activity of systemic Lupus erythematosus. Lupus 23 (8), 793 - 801. D0I: 10.1177/0961203314530792. Epub 2014 Apr. 23.

Salas, R.N., Malina, D. \& Solomon, C.G. (2019). Prioritizing health in a changing climate. The New England Journal of Medicine 381,773 - 774. DOI: 10.1056/NEJMe1909957.

Salzberg, S.L. (2018). Open questions: How many genes do we have? BMC Biology 16, 94. https://doi.org/10.1186/s12915-018-0564-x (accessed 23.11.2020).

Sarmadi, M., Bidel, Z., Najafi, F., Ramakrishnan, R., Teymoori, F., AzhdariZarmehri, H. \& Nazarzadeh, M. (2020). Copper concentration in multiple sclerosis: A systematic review and meta-analysis. Multiple Sclerosis and Related Disorders 45, 102426. https://doi.org/10.1016/j.msard.2020.102426 (accessed 02.02.2021).

Sartwell, P.E. \& Edwards, L.B. (1974). Epidemiology of sarcoidosis in the U.S. Navy. American Journal of Epidemiology 99, 250 - 257. https://doi.org/10.1093/oxfordjournals.aje.a121609 (accessed 05.09.2021).

Sawczenko, A. \& Fleming, P.J. (1996). Thermal stress, sleeping position, and the sudden infant death syndrome. Sleep 19 (10), S267 - S270. American Sleep Disorders Association and Sleep Research Society. file://CC:/Users/Admin/Downloads/Thermal_Stress_Sleeping_Position_and_the_Sudden_In.pdf (accessed 05.09.2021).

Scanlon, S.T. (2020). The immune system's first Steps. In: C. Tsevis (Ed.), Early Life Immunology. Science 368 (6491), 598 - 599. DOI: $10.1126 /$ science.abc3140.

Schiffrin, E.L., Lipman, M.L. \& Mann, J.F.E. (2007). Chronic Kidney Disease: Effects on the Cardiovascular System. Circulation 116, 85 97. https://doi.org/10.1161/CIRCULATIONAHA.106.678342 (accessed 31.08.2020).

Schluter, P.J., Ford, R.P., Brown, J. \& Ryan, A.P. (1998). Weather temperatures and sudden infant death syndrome: A regional study over 22 years in New Zealand. Journal of Epidemiology and Community Health 52 (1), 27 - 33. DOI: 10.1136/jech.52.1.27.

Sealey, L.A., Hughes, B.W., Sriskanda, A.N., Guest, J.R., Gibson, A.D., Johnson-Williams, L., Pace, D.G. \& Bagasra, O. (2016). Environmental factors in the development of autism spectrum disorders. Environment International 88, 288 - 298. https://doi.org/10.1016/j.envint.2015.12.021 (accessed 22.08.2021).

Senanayake, N. \& King, B. (2017). Health-environment futures: Complexity, uncertainty, and bodies. Progress in Human Geography 43 (4), 711 728. https://doi.org/10.1177/0309132517743322 (accessed 26.11.2020).

Sendur, O.F., Tastaban, E., Turan, Y. \& Ulman, C. (2008). The relationship between serum trace element levels and clinical parameters in patients with fibromyalgia. Rheumatology International 28 (11), 1117 - 1121. https://doi.org/10.1007/s00296-008-0593-9 (accessed 21.08.2021).

Sengupta P. (2013). Potential health impacts of hard water. International Journal of Preventive Medicine 4 (8), 866 - 875. https://www.ncbi.nlm.nih.gov/pmc/articles/PMC3775162/ (accessed 05.09.2021).

Ship, J.A., Phelan, J. \& Kerr, A.R. (2003). Biology and Pathology of the Oral Mucosa. In: I.M. Freedberg, A.Z. Eisen, K. Wolff et al. (Eds.), Fitzpatrick's Dermatology in General Medicine (6 ${ }^{\text {th }}$ Ed.), Chapter 112., p. 1208. McGraw-Hill. ISBN 0-07-138067-1. 
Shmool, J.L., Kubzansky, L.D., Newman, O.D., Spengler, J., Shepard, P. \& Clougherty, J.E. (2014). Social stressors and air pollution across New York City communities: A spatial approach for assessing correlations among multiple exposures. Environmental Health 13, 91. DOI: 10.1186/1476-069X-13-91.

Shukla, V., Das, S.K., Mahdi, A.A., Agarwal, S., Alok, R., Ansari, J.A. \& Khandpur, S., 2021. Metal-induced oxidative stress level in patients with fibromyalgia syndrome and its contribution to the severity of the disease: A correlational study. Journal of Back and Musculoskeletal Rehabilitation 34 (2), 319 326. https://doi.org/10.3233/BMR-200102 (accessed 21.08.2021).

Sian, J., Youdim, M.B.H., Riederer, P. \& Gerlach, M. (1999). Parkinson's Disease. In: G.J. Siegel, B.W. Agranoff, R.W. Albers, et al. (Eds.), Basic Neurochemistry: Molecular, Cellular and Medical Aspects. $6^{\text {th }}$ edition; Chapter 45. Philadelphia: Lippincott-Raven.

Sierpina, V.S. \& Carter, R. (2002). Alternative and integrative treatment of fibromyalgia and chronic fatigue syndrome. Clinics in Family Practice 4 (4), 853 - 872. 872. https://citeseerx.ist.psu.edu/viewdoc/download?doi=10.1.1.539.9249\&rep=rep1\&type=pdf (accessed 02.02.2021).

Simon, A.K., Hollander, G.A. \& McMichael, A. (2015). Evolution of the immune system in humans from infancy to old age. Proceedings of the Royal Society B: Biological Sciences 282 (1821), 20143085. https://doi.org/10.1098/rspb.2014.3085 (accessed 25.12.2020).

Simpson, J. \& Weiner, E. (Eds.) (2002). The Oxford English Dictionary, 2 ${ }^{\text {nd }}$ Edition. Oxford University Press. ISBN 0-19-521942-2.

Siracusa, R., Paola, R.D., Cuzzocrea, S. \& Impellizzeri, D. (2021). Fibromyalgia: Pathogenesis, mechanisms, diagnosis and treatment options update. International Journal of Molecular Sciences 22 (8), 3891. https://doi.org/10.3390/ijms22083891 (accessed 22.08.2021).

Simpson, S. Jnr., Blizzard, L., Otahal, P., Van der Mei, I. \& Taylor, B. (2011). Latitude is significantly associated with the prevalence of multiple sclerosis: A metaanalysis. Journal of Neurology and Neurosurgical Psychiatry 82 (10), 1132 - 1141. DOl:10.1136/jnnp.2011.240432.

Simpson, S. Jnr., Wang, W., Otahal, P., Blizzard, L., van der Mei, I.A.F. \& Taylor, B.V. (2019). Latitude continues to be significantly associated with the prevalence of multiple sclerosis: An updated meta-analysis. Journal of Neurology and Neurosurgical Psychiatry 90 (11), 1193 - 1200. DOI: 10.1136/jnnp-2018-320189.

Smith, T. (1934). Parasitism and Disease. Princeton University Press, Princeton, N.J., 196 pp. https://doi.org/10.1038/136738a0 (accessed 05.09.2021).

Smith, D.K., Feldman, E.B. \& Feldman, D. S. (1989). Trace element status in multiple sclerosis. American Journal of Clinical Nutrition 50 (1), 136 - 140. DOI:10.1093/ajcn/50.1.136.

Smith, B., Chenery, S.R.N., Cook J.M., Styles, M.T., Tiberindwa, J.V., Hampton, C., Freers, J., Rutakinggirwa, M., Sserunjogi, L., Tomkins, A. \& Brown, C.J. (1998).

Geochemical and environmental factors controlling exposure to cerium and magnesium in Uganda. Journal of Geochemical Exploration 65 (1), 1 - 15. https://doi.org/10.1016/S0375-6742(98)00066-1 (accessed 20.08.2021).

Smith, D.A. \& Germolec, D.R. (1999). Introduction to immunology and autoimmunity. Environmental Health Perspectives 107 (Suppl 5), 661 665. https://doi.org/10.1289/ehp.99107s5661 (accessed 08.12.2020).

Smith, K.R., Woodward, A., Campbell-Lendrum, D., Chadee, D.D., Honda, Y., Liu, Q., Olwoch, J.M., Revich, B. \& Sauerborn, R. (2014). Human health: Impacts, adaptation, and co-benefits. In: Field, C.B., Barros, V.R., Dokken, D.J., Mach, K.J., Mastrandrea, M.D. et al. (Eds.), Climate Change 2014: Impacts, Adaptation, and 
Vulnerability. Part A: Global and Sectoral Aspects. Contribution of Working Group II to the Fifth Assessment Report of the Intergovernmental Panel on Climate Change]. Cambridge University Press, Cambridge, United Kingdom and New York, NY, USA, pp. 709 - 754.

Smith, D.B., Solano, F., Woodruff, L.G., Cannon, W.F. \& Ellefsen, K.J. (2019). Geochemical and Mineralogical Maps, With Interpretation, for Soils of the Conterminous United States. US Geological Survey Scientific Investigations Report 2017-5118. https://pubs.er.usgs.gov/publication/sir20175118 (accessed 03.12.2020).

Smoyer-Tomic, K.E., Kuhn, R. \& Hudson, A. (2003). Heat wave hazards: An overview of heat wave impacts in Canada. Natural Hazards 28, 465 486. https://doi.org/10.1023/A:1022946528157 (accessed 11.01.2021).

Song, C. \& Kulldorff, M. (2003). Power evaluation of disease clustering tests. International Journal of Health Geographics 2 (1), 9. https://doi.org/10.1186/1476-072X-2-9 (accessed 28.01.2021).

Sorensen, C. \& Garcia-Trabanino, R. (2019). A new era of climate medicine - Addressing heat-triggered renal disease. New England Journal of Medicine 381, 693 - 696. DOI: 10.1056/NEJMp1907859.

Soriano, J.B., Abajobir, A.A., Abate, K.H., Abera, S.F., Agrawal, A. \& Ahmed, M.B. (2017). Global, regional, and national deaths, prevalence, disability-adjusted life years, and years lived with disability for chronic obstructive pulmonary disease and asthma, 1990 - 2015: A systematic analysis for the Global Burden of Disease Study 2015. Lancet Respiratory Medicine 5, 691 - 706. DOI: 10.1016/S2213-2600(17)30293-X

Srour, M.L., Marck, K. \& Baratti-Mayer, D. (2017). Noma: Overview of a neglected disease and human rights violation. The American Journal of Tropical Medicine and Hygiene 96 (2), 268 - 274. https://doi.org/10.4269/ajtmh.16-0718 (accessed 02.02.2021).

Srour, M.L. \& Baratti-Mayer, D. (2020). Why is noma a neglected-neglected tropical disease? PLoS Neglected Tropical Diseases 14 (8): e0008435. https://doi.org/10.1371/journal.pntd.0008435 (accessed 02.09.2021).

Stanaway, J.D., Afshin, A., Gakidou, E., Lim, S.S., Abate, D., Abate, K.H. et al. (2018). Global, regional, and national comparative risk assessment of 84 behavioural, environmental and occupational, and metabolic risks or clusters of risks for 195 countries and territories, 1990 - 2017: a systematic analysis for the Global Burden of Disease Study 2017. The Lancet: Global Health Metrics 392 (10159), 1923 - 1994. https://doi.org/10.1016/S0140-6736(18)32225-6 (accessed 05.09.2021).

Staples, J.A., Ponsonby, A.L., Lim, L.L. \& McMichael, A.J. (2003). Ecologic analysis of some immune-related disorders, including type 1 diabetes, in Australia: Latitude, regional ultraviolet radiation, and disease prevalence. Environmental Health Perspectives 111 (4), 518 - 23. DOI:

10.1289/ehp.5941. https://ehp.niehs.nih.gov/doi/pdf/10.1289/ehp.5941(accessed 17.01.2021).

Steele, R.J., Fogerty, A.C., Willcox, M.E. \& Clancy, S.L. (1984). Metal content of the liver in sudden infant death syndrome. Journal of Paediatrics and Child Health 20 (2), $141-142$.

https://onlinelibrary.wiley.com/doi/epdf/10.1111/j.1440-1754.1984.tb00063.x (accessed 31.10.2020

Stejskal, V., Ockert, K. \& Bjørklund, G. (2013). Metal-induced inflammation triggers fibromyalgia in metal-allergic patients. Neuro Endocrinology Letters 34 (6), 559 - 565. file:///C:/Users/Admin/Downloads/Metal_induced_inflammation_triggers_fibr.pdf (accessed 05.09.2021). 
Stewart, C.G. \& Burroughs, G.W. (Undated). Infectious Diseases of Livestock, Part 3: Disease Complexes - Unknown Aetology: III-thrift.

Anipedia. https://www.anipedia.org/resources/disease-complexes-/-unknown-aetiology-ill-thrift/982 (accessed 31.10.2020).

Sun, H. (2018). Association of soil selenium, strontium, and magnesium concentrations with Parkinson's disease mortality rates in the USA. Environmental Geochemistry and Health 40, 349 - 357. https://link.springer.com/article/10.1007/s10653-017-9915-8 (accessed 28.01.2021).

Taibo, C.L.A., Cliff, J., Rosling, H., Hall, C.D., Park, M.M. \& Frimpong, J.A. (2017). An epidemic of spastic paraparesis of unknown aetiology in Northern Mozambique. Pan African Medical Journal 27 (Supplement 1), 6. DOI: 10.11604/pamj.supp.2017.27.1.12623. https://www.panafrican-medjournal.com/content/series/27/1/6/full/27-1-6.pdf (accessed 29.01.2021).

Tamburo, E., Varrica, D., Dongarrà, G. \& Grimaldi, L.M.E. (2015). Trace elements in scalp hair samples from patients with relapsing-remitting Multiple Sclerosis. PLoS One 10 (4): e0122142. DOI: 10.1371/journal.pone.0122142. https://journals.plos.org/plosone/article?id=10.1371/journal.pone.0122142 (accessed 31.08.2020).

Tavassolifar, M.J., Vodjgani, M., Salehi, Z. \& Izad, M. (2020). The Influence of reactive oxygen species in the immune system and pathogenesis of multiple sclerosis. Autoimmune Diseases 2020, 5793817. DOI: 10.1155/2020/5793817. https://www.researchgate.net/publication/345741533.... (accessed 18.01.2021).

Taylor, C.A., Greenlund, S.F., McGuire, L.C., Lu, H. \& Croft, J.B. (2017). Deaths from Alzheimer's Disease - United States, 1999 - 2014. MMWR Morbidity and Mortality Weekly Report 2017. DOI: 10.15585/mmwr.mm6620a1.

Tesher, M.S. (2019). Pediatric autoimmune diseases. Pediatric Annals 48 (10): e385-e386. DOI: 10.3928/19382359-20190924-

02. https://doi.org/10.3928/19382359-20190924-02 (accessed 26.12.2020).

Tharakan, J. \& Bohora, S. (2009). Current perspective on endomyocardial fibrosis. Current Science 97 (3), 405 - 410. http://www.jstor.org/stable/24112008 (accessed 20.08.2021).

Theron, A., Tintinger, G.R. \& Anderson, R. (2012). R. Harmful interactions of non-essential heavy metals with cells of the innate immune system. Journal of Clinical Toxicology, (Supplement 3:005). DOI: 10.4172/2161-0495.S3-005. ISSN: 2161-0495. https://www.longdom.org/open-access/harmful-interactions-ofnon-essential-heavy-metals-with-cells-of-the-innate-immune-system-2161-0495.S3-005.pdf (accessed 30.01.2021).

Thielke, S., Slatore, C.G. \& Banks, W.A. (2015). Association between Alzheimer Dementia mortality rate and altitude in California Counties. JAMA Psychiatry 72 (12), 1253 - 1254. DOI:10.1001/jamapsychiatry.2015.1852.

Thomas, J. (2019). Increasing the altitude to decrease the symptoms of Parkinson's Disease. High Altitude Health. https://highaltitudehealth.com/2019/04/15/increasing-the-altitude-to-decrease-the-symptoms-of-parkinsons-disease/(accessed 13.09.2020).

Thrall, G.I. (1999). The future of GIS in public health management and practice. Journal of Public Health Management and Practice 5 (4), 75 - 82. https://journals.Iww.com/jphmp/citation/1999/07000/the_future_of_gis_in_public_health_management_and.14.aspx (accessed 05.09.2021).

Thurnham, D.I. (2004). An overview of the interactions between micronutrients and of micronutrients with drugs, genes and immune mechanisms. Nutrition Research Reviews 17 (2), 211 - 240. Cambridge University Press. DOI: 10.1079/NRR200486.

Toubiana, J., Poirault, C., Corsia, A., Bajolle, F., Fourgeaud, J., Angoulvant, F., Debray, A., et al. (2020). Kawasaki-like multisystem inflammatory syndrome in children during the covid-19 pandemic in Paris, France: Prospective observational study. BMJ 369 (m2094). https://www.bmj.com/content/369/bmj.m2094 (accessed 30.08.2020). 
Tseng, W.P. (1977). Effects and dose-response relationships of skin cancer and blackfoot disease with arsenic. Environmental Health Perspectives 19, 109119. https://www.ncbi.nlm.nih.gov/pmc/articles/PMC1637425/pdf/envhper00485-0107.pdf (accessed 05.09.2021).

Tsevis, C. (Ed.) (2020). Early Life Immunology. Special Issue, Science 368 (6491). Published by the American Association for the Advancement of Science. https://www.science.org/toc/science/368/6491 (accessed 05.09.2021).

Tulchinsky, T.H. (2018). John Snow, cholera, the Broad Street Pump: Waterborne diseases then and now. Case Studies in Public Health 2018,77 99. https://www.ncbi.nlm.nih.gov/pmc/articles/PMC7150208/ (accessed 02.01.2021).

UCSDH (UC San Diego Health) (2013). Data from Across Globe Defines Distinct Kawasaki Disease Season. https://health.ucsd.edu/news/releases/Pages/2013-09-23-data-defines-kawasaki-disease-seasonal.aspx (accessed 28.08.2020).

UKRI/NIHR (UK Research and Innovation/National Institute for Health Research) Project (2020). Tackling multimorbidity at scale: Understanding disease clusters, determinants and biological pathways. https://mrc.ukri.org/funding/browse/tackling-multimorbidity/tackling-multimorbidity-at-scale/ (accessed 03.01.2021).

Ullah, I., Zhao, L., Hai, Y., Fahim, M., Alwayli, D., Wang, X. \& Li, H. (2021). Metal elements and pesticides as risk factors for Parkinson's disease - A review. Toxicology Reports 8, 607 - 616. https://doi.org/10.1016/j.toxrep.2021.03.009 (accessed 02.09.2021).

US CDC (United States Centres for Disease Control and Prevention) (1990). Guidelines for Investigating Clusters of Health Events. Morbidity and Mortality Weekly Reports 39 (RR-11); 1 - 16. https://www.cdc.gov/mmwr/preview/mmwrhtml/00001797.htm (accessed 05.09.2021).

US CDC (United States Centres for Disease Control and Prevention) (2018). Myalgic Encephalomyelitis/Chronic Fatigue Syndrome: Diagnosis of ME/CFS. https://www.cdc.gov/me-cfs/symptoms-diagnosis/diagnosis.html (accessed 29.10.2020).

US CDC (US Centers for Disease Control and Prevention) (2020). Climate Effects on Health; and Cited Bibliography Within. https://www.cdc.gov/climateandhealth/effects/default.htm (accessed 25.11.2020).

US EPA (US Environmental Protection Agency) (2021). Criteria Air Pollutants. https://www.epa.gov/criteria-air-pollutants (accessed 02.09.2021).

US NIEHS (National Institute of Environmental Health Sciences) (2020). Environmental

Epigenetics. https://www.niehs.nih.gov/research/supported/health/envepi/index.cfm (accessed 12.12.2020).

US NIH (United States National Institute of Health) (2019). Hereditary Spastic Paraplegia Information Page. https://www.ninds.nih.gov/Disorders/AllDisorders/Hereditary-Spastic-Paraplegia-Information-Page (accessed 29.10.2020).

US NINDS (United States National Institute of Neurological Disorders and Stroke) (2014). Hereditary Spastic Paraplegia Information Page. https://web.archive.org/web/20140221102852/http://www.ninds.nih.gov/disorders/hereditary_spastic_paraplegia/hereditary_spastic_paraplegia.htm (accessed 29.10.2020). 
US NRC (US National Research Council Committee on Climate, Ecosystems, Infectious Diseases, and Human Health) (2001). Under the Weather: Climate, Ecosystems, and Infectious Disease. Washington (DC): National Academies Press (US); 2001.4, Climate Influences on Specific Diseases. https://www.ncbi.nlm.nih.gov/books/NBK222258/ (accessed 18.12.2020).

Uzuner, N., Karaman, Ö., Coker, C., Turgut, F., Uzuner, H. \& Önvural, B. (2001). Serum trace element levels in bronchial asthma, Vol. 2. Turkish Respiratory Journal 2 (3), 10 - 15. https://www.researchgate.net/publication/267256530_Serum_Trace_Element_Levels_in_Bronchial_Asthma (accessed 05.09.2021).

van Horssen, J., Witte, M.E., Schreibelt, G. \& de Vries, H.E. (2011). Radical changes in multiple sclerosis pathogenesis. Biochimica et Biophysica Acta (BBA) Molecular Basis of Disease 1812 (2), 141 - 150. DOl: 10.1016/j.bbadis.2010.06.011. Epub 2010 Jun 27. https://www.sciencedirect.com/science/article/pii/S0925443910001213 (accessed 18.01.2021).

Wade, B.J. (2014). Spatial analysis of global prevalence of multiple sclerosis suggests need for an updated prevalence scale. Multiple Sclerosis International 2014, 124578. https://doi.org/10.1155/2014/124578 (accessed 20.08.2021).

Wang, X., Zhang, Q. \& Zhou, G. (2007). National-Scale Geochemical Mapping Projects in China. Geostandards and Geoanalytical Research 31 (4), 311 -320. https://doi.org/10.1111/j.1751-908X.2007.00128.x (accessed 02.02.2021).

Wang, L., Yin, Y.L., Liu, X.Z., Peng, S., Zheng, Y-G., Lan, X-R, Lu, C-B. \& Wang, J-Z, 2020. Current understanding of metal ions in the pathogenesis of Alzheimer's disease. Translational Neurodegeneration 9, 10 (2020). https://doi.org/10.1186/s40035-020-00189-z (accessed 30.01.2021).

Wanigasuriya, K.P., Peiris-John, R.J. \& Wickremasinghe, R. (2011). Chronic kidney disease of unknown aetiology in Sri Lanka: Is cadmium a likely cause? BMC Nephrology 12 (32). https://doi.org/10.1186/1471-2369-12-32 (accessed 02.02.2021).

Warren, S \& Warren, K.G. (2001). Multiple Sclerosis. World Health Organisation, Geneva.

https://apps.who.int/iris/bitstream/handle/10665/42394/924156203X_en.pdf (accessed 17.01.2021).

Watad, A., Azrielant, S., Bragazzi, N.L., Sharif, K., David, P., Katz, I., Aljadeff, G., Quaresma, M., Tanay, G., Adawi, M., Amital, H. \& Shoenfeld, Y. (2017). Seasonality and autoimmune diseases: The contribution of the four seasons to the mosaic of autoimmunity. Journal of Autoimmunity 82,13 - 30 . DOI: 10.1016/j.jaut.2017.06.001. Epub 2017 Jun 16.

Wei, Y., Wang, Y., Lin, C-K., Yin, K., Yang, J., Shi, L., Li, L., Zanobetti, A. \& Schwartz, J.D. (2019). Associations between seasonal temperature and dementiaassociated hospitalizations in New England. Environment International 126, 228 - 233. DOI: 10.1016/j.envint.2018.12.054.

WGBD (World Global Burden of Disease 2016 Multiple Sclerosis Collaborators: Wallin, M.T., Culpepper, W.J., Nichols, E., Bhutta, Z.A., Gebrehiwot, T.T., Hay, S.S. et al. (2019). Global, regional, and national burden of multiple sclerosis 1990 - 2016: A Systematic Analysis for the Global Burden of Disease Study 2016. The Lancet Neurology 18 (3), 269 - 285. DOI: 10.1016/S1474-4422(18)30443-5.

Whitty, C.J.M., MacEwen, C., Goddard, A., Alderson, D., Marshall, M. et al. (2020). Rising to the challenge of multimorbidity: We need to combine generalist and specialist skills. Editorial. BMJ 368, 16964. DOI: https://doi.org/10.1136/bmj.l6964 (accessed 04.01.2021).

WHO (World Health Organisation) (2003). Climate Change and Human Health - Risks and Responses. Summary. WHO/WMO/UNEP [E], ISBN 9241590815. 37 pp. https://www.who.int/globalchange/environment/en/ccSCREEN.pdf?ua=1 (accessed 25.11.2020). 
WHO (World Health Organisation) (2011). Public Health and Environment. Global Strategy

Overview. https://www.who.int/phe/publications/PHE_2011_global_strategy_overview_2011.pdf (accessed 24.01, 2001).

WHO (World Health Organisation) (2018a). Cancer. https://www.who.int/news-room/fact-sheets/detail/cancer (accessed 11.12.2020).

WHO (World Health Organisation) (2018b). Climate Change and Health. https://www.who.int/news-room/fact-sheets/detail/climate-change-andhealth\#: :text=Climate\%20change\%20affects\%20the\%20social,malaria\%2C\%20diarrhoea\%20and\%20heat\%20stress (accessed 25.11.2020).

WHO (World Health Organisation) (2021). Climate Change and Human Health - Information and Public Health Advice: Heat and Health. https://www.who.int/globalchange/publications/heat-and-health/en/ (accessed 11.01. 2021).

Wickramarathna, S., Balasooriya, S., Diyabalanage, S. \& Chandrajith, R. (2017). Tracing environmental aetiological factors of chronic kidney diseases in the dry zone of Sri Lanka - A hydrogeochemical and isotope approach. Journal of Trace Elements in Medicine and Biology: Organ of the Society for Minerals and Trace Elements (GMS) 44, 298 - 306. DOI: 10.1016/j.jtemb.2017.08.013.

Wijetunge, S., Ratnatunga, N.V., Abeysekera, T.D., Wazil, A.W. \& Selvarajah, M. (2015). Endemic chronic kidney disease of unknown etiology in Sri Lanka: Correlation of pathology with clinical stages. Indian Journal of nephrology 25(5), 274 - 280. https://doi.org/10.4103/0971-4065.145095 (accessed 02.02.2021).

Willadsen, T.G., Bebe, A., Køster-Rasmussen, R., Jarbøl, D.E., Guassora, A.D., Waldorff, F.B., Reventlow, S. \& Olivarius, N. (2016). The role of diseases, risk factors and symptoms in the definition of multimorbidity - A systematic review. Scandinavian Journal of Primary Health Care 34 (2), 112 -

121. https://doi.org/10.3109/02813432.2016.1153242 (accessed 19.11.2020).

Wilson, M.L. (2001). Ecology and infectious disease. In: J.L. Aron \& J.A. Patz (Eds.), Ecosystem Change and Public Health: A Global Perspective, Baltimore, USA, John Hopkins University Press, pp. 283 - 324. ISBN: 9780801865824.

Winans, B., Humble, M.C. \& Lawrence, B.P., 2011. Environmental toxicants and the developing immune system: A missing link in the global battle against infectious disease? Reproductive Toxicology (Elmsford, N.Y.) 31 (3), 327 - 336. https://doi.org/10.1016/j.reprotox.2010.09.004 (accessed 02.02.2021).

Wimalawansa, S.J. and Dissanayake, C.B. (2020). Factors affecting the environmentally induced, chronic kidney disease of unknown aetiology in dry zonal regions in tropical countries - Novel findings. Environments 7(1), 2. DOI: 10.3390/environments7010002.

https://doi.org/10.3390/environments7010002 (accessed 28.01.2021).

Wu, X., Lu, Y., Zhou, S., Chen, L. \& Xu, B. (2016). Impact of climate change on human infectious diseases: Empirical evidence and human adaptation. Environment International 86, 14 - 23. ISSN 0160-4120. http://www.sciencedirect.com/science/article/pii/S0160412015300489 (accessed 19.12.2020).

Xie, X., Wang, X., Zhang, Q., Zhou, G., Cheng, H., Liu, D., Cheng, Z. \& Xu, S. (2008). Multi-scale geochemical mapping in China. Geochemistry: Exploration, Environment, Analysis 8, 333 - 341. https://doi.org/10.1016/j.gexplo.2013.06.003 (accessed 05.09.2021).

Yanagihara, R., Garruto, R.M., Gajdusek, D.C., Tomita, A., Uchikawa, T., Konagaya, Y., Chen, K.M., Sobue, I., Plato, C.C. \& Gibbs, C.J. Jr. (1984). Calcium and vitamin D metabolism in Guamanian Chamorros with amyotrophic lateral sclerosis and parkinsonism-dementia. Annals of Neurology 15 (1), 42 48. DOI: 10.1002/ana.410150108. 
Yang, S., and Lian, G. (2020(. ROS and diseases: Role in metabolism and energy supply. Molecular and Cellular Biochemistry 467 (1 - 2), 1 12. https://doi.org/10.1007/s11010-019-03667-9 (accessed 18.01.2021).

Yase, Y. (1972). The pathogenesis of amyotrophic lateral sclerosis. The Lancet 2 (7772), 292 - 296. DOI: 10.1016/s0140-6736(72)92903-

0. https://www.thelancet.com/journals/lancet/article/PIIS0140-6736(72)92903-0/fulltext (accessed 28.01.2021).

Yasui, M., Kihira, T. \& Ota, K. (1992). Calcium, magnesium and aluminum concentrations in Parkinson's disease. Neurotoxicology 13 (3), 593 - 600.

https://www.semanticscholar.org/paper/Calcium\%2C-magnesium-and-aluminum-concentrations-in-Yasui-

Kihira/456590610cfe818c3744fdc1d884a348d3c598d1 (accessed 05.09.2021). [Abstract only].

Ye, X., Wolff, R., Yu, W., Vaneckova, P., Pan, X. \& Tong, S. (2012). Ambient temperature and morbidity: A review of epidemiological evidence. Environmental Health Perspectives 120 (1), 19 - 28. https://www.ncbi.nlm.nih.gov/pmc/articles/PMC3261930/ (accessed 11.01.2021).

Yeter, D., Portman, M.A., Aschner, M., Farina, M., Chan, W.C., Hsieh, K.S. \& Kuo, H.C. (2016). Ethnic Kawasaki disease risk associated with blood mercury and cadmium in U.S. children. International Journal of Environmental Research and Public Health 13 (1), 101. https://www.mdpi.com/1660-4601/13/1/101/htm (accessed 30.12.2020).

Zhang, J., Li, X., Shen, L., Khan, N.U., Zhang, X., Chen, L., Zhao, H. \& Luo, P. (2021). Trace elements in children with autism spectrum disorder: A meta-analysis based on case-control studies. Journal of Trace Elements in Medicine and Biology 67, 126782. DOI: 10.1016/j.jtemb.20.

Zhao, H.W., Lin, J., Wang, X.B., Cheng, X., Wang, J.Y., Hu, B.L., Zhang, Y., Zhang, X. \& Zhu, J.H. (2013). Assessing plasma levels of selenium, copper, iron and zinc in patients of Parkinson's disease. PloS One 8 (12), e83060. https://doi.org/10.1371/journal.pone.0083060 (accessed 02.02.2021).

\section{Tables}

.. Examples from the global literature on diseases of unknown aetiology (DUA) having one or more possible or suspected geochemical other geoenvironmental variable(s) as causal cofactor

\section{Figures}

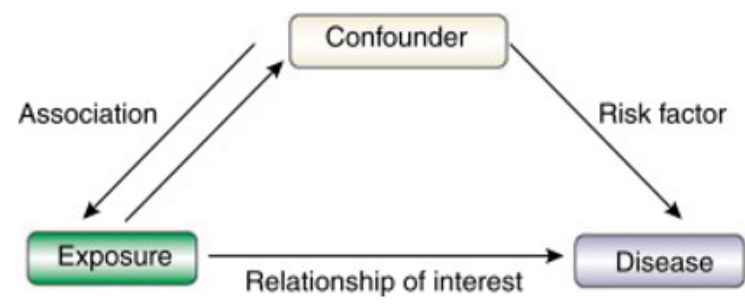

\section{Figure 1}

The structure of confounding. Source: Jager et al., 2008. 


\begin{tabular}{|c|c|c|c|c|c|}
\hline DUA & Presentation & $\begin{array}{l}\text { Incidence/Geographical } \\
\text { Distribution/Demographical } \\
\text { Pattern }\end{array}$ & $\begin{array}{l}\text { Geochemical variable (Including Trace Element } \\
\text { Mediated Immune Response) }\end{array}$ & $\begin{array}{l}\text { Geoclimatic and } \\
\text { Seasonal Variations }\end{array}$ & Remarks \\
\hline 1. Acrocyanosis & $\begin{array}{l}\text { Acrocyanosis is a peripheral } \\
\text { vascular disorder which } \\
\text { presents as a persistent bluish } \\
\text { or cyanotic discolouration of } \\
\text { the extremities, most } \\
\text { commonly occurring in the } \\
\text { hands }\end{array}$ & $\begin{array}{l}\text { Geographical locale } \\
\text { (latitude; urban versus rural } \\
\text { setting) uncertain - } \\
\text { Kurklinsky et al., } 2011\end{array}$ & $\begin{array}{l}\text { Chronic As toxicity - Grobe, 1976; Tseng, 1977; } \\
\text { Mak, 1988; Kurklinsky et al., } 2011\end{array}$ & $\begin{array}{l}\text { Cold climate - Crocq, } \\
\text { 1896; Carpentier, 1998; } \\
\text { Cold environments - } \\
\text { Das and Maiti, 2013; } \\
\text { Kent and Carr, 2020 }\end{array}$ & $\begin{array}{l}\text { "Diagnosis remains } \\
\text { mostly clinical, and } \\
\text { pathological } \\
\text { mechanisms vary, } \\
\text { suggesting that } \\
\text { acrocyanosis may not } \\
\text { be a single entity" - } \\
\text { Kurklinsky et al., } \\
2011\end{array}$ \\
\hline $\begin{array}{l}\text { 2. Acute Febrile } \\
\text { Illness }\end{array}$ & $\begin{array}{l}\text { Acute Febrile Illness (AFI) is } \\
\text { characterised by malaise, } \\
\text { myalgia (pain in muscle or } \\
\text { group of muscles) and a raised } \\
\text { temperature that is a } \\
\text { nonspecific manifestation of } \\
\text { infectious diseases in the } \\
\text { tropics (Bashkaran et al., } \\
\text { 2019) }\end{array}$ & $\begin{array}{l}\text { Sub-Saharan Africa; Tropics } \\
\text { and Sub-Tropics }\end{array}$ & $\begin{array}{l}\text { Viral respiratory tract infections - Crump et al., } \\
\text { 2013; D'Acremont et al., 2014; Significantly lower } \\
\text { serum Zn levels in febrile seizure group than in the } \\
\text { afebrile group - Lee and Kim, 2012; No significant } \\
\text { relationship observed between fabrile convulsion } \\
\text { and the elements: Fe, Zn, Mg and Ca - Amouian et } \\
\text { al., } 2013\end{array}$ & $\begin{array}{l}\text { Clear seasonal trend } \\
\text { observed - Kaboré et } \\
\text { al., } 2020\end{array}$ & $\begin{array}{l}\text { Further research is } \\
\text { warranted on trace } \\
\text { element metabolism } \\
\text { in relation to the } \\
\text { development of AFI - } \\
\text { See: Amouian et al., } \\
2013\end{array}$ \\
\hline $\begin{array}{l}\text { 3. Acute Severe } \\
\text { Asthma }\end{array}$ & $\begin{array}{l}\text { Asthma is characterised by } \\
\text { chronic airway inflammation, } \\
\text { resulting in periodic wheeze, } \\
\text { cough and breathlessness } \\
\text { (See: Carlsson and Bayes, } \\
2020 \text { ) }\end{array}$ & $\begin{array}{l}\text { Worldwide prevalence. The } \\
\text { Global Asthma Report of } \\
2017 \text { recorded a figure of } \\
\text { approximately } 334 \text { million } \\
\text { for the number of people in } \\
\text { the world suffering from } \\
\text { asthma, thus making this } \\
\text { condition the most } \\
\text { prevalent chronic } \\
\text { respiratory disease } \\
\text { (Soriano et al., 2017) }\end{array}$ & $\begin{array}{l}\text { Respiratory tract infections - Johnston et al., 1995; } \\
\text { Jackson and Johnston 2010; Air pollution - Guarnieri } \\
\text { and Balmes; 2014; Shmool et al., 2014; Decrease in } \\
\text { antioxidant capacity in bronchial asthma as serum } \\
\text { Se and Zn levels decrease, leading to further } \\
\text { increase in oxidant stress and resulting enhanced } \\
\text { inflammation and hyperreactivity in the airways - } \\
\text { Uzuner et al., 2001; Low Se and Cu levels may have } \\
\text { a role in bronchial asthma in Sudan, north-central } \\
\text { Africa - Hussein et al., } 2008\end{array}$ & $\begin{array}{l}\text { Recent global rise in } \\
\text { asthma, an early health } \\
\text { effect of anthropogenic } \\
\text { climate change - Beggs } \\
\text { and Bambrick, } \\
\text { 2005; Cecchi et al., } \\
\text { 2010; Weather } \\
\text { changes/cold weather } \\
\text { - Hyrkäs et al., 2016; } \\
\text { D'Amato et al., 2018 }\end{array}$ & $\begin{array}{l}\text { The precise } \\
\text { mechanisms by which } \\
\text { these environmental } \\
\text { stimuli and viruses } \\
\text { initiate asthma or } \\
\text { cause worsening of } \\
\text { the disease are still } \\
\text { unknown - Kostakou } \\
\text { et al., } 2019\end{array}$ \\
\hline $\begin{array}{l}\text { 4. Alzheimer's } \\
\text { Disease }\end{array}$ & $\begin{array}{l}\text { Alzheimer's Disease (AD) is } \\
\text { the most common } \\
\text { neurodegenerative disorder } \\
\text { and the leading cause } \\
\text { of dementia (i.e., the } \\
\text { particular group of symptoms } \\
\text { shown). It becomes worse with } \\
\text { time (degenerative). The } \\
\text { symptoms expressed are as a } \\
\text { result of the damage or } \\
\text { destruction of nerve cells } \\
\text { (neurons) in parts of the brain } \\
\text { involved in thinking, learning } \\
\text { and memory (cognitive } \\
\text { function) }\end{array}$ & $\begin{array}{l}\text { By } 2009 \text {, the global } \\
\text { prevalence of dementia was } \\
\text { estimated at } 3.9 \% \text { in people } \\
\text { aged } 60+\text { years, with the } \\
\text { regional prevalence being } \\
1.6 \% \text { in Africa, } 4.0 \% \text { in } \\
\text { China and Western Pacific } \\
\text { regions, } 4.6 \% \text { in Latin } \\
\text { America, } 5.4 \% \text { in Western } \\
\text { Europe, and } 6.4 \% \text { in North } \\
\text { America (Qui et al., 2009); } \\
\text { Geographical variation } \\
\text { (latitude) plays key role in } \\
\text { dementia risk (e.g., Russ et } \\
\text { al., 2016) }\end{array}$ & $\begin{array}{l}\text { Significantly different }(\rho<0.05) \text { mean } \\
\text { concentrations of Br, Cl, Ce, Hg, N, Na, P, and Rb } \\
\text { were observed in AD bulk brain samples compared } \\
\text { to controls - Ehmann et al., 1986; Varying trace } \\
\text { element relationships with AD severity, with Al } \\
\text { deposits greater in severely affected AD brain - } \\
\text { Jagannatha Rao et al., 1999; Loef and Walach, 2012; } \\
\text { Biometal dyshomeostasis and toxic metal } \\
\text { accumulations - Chapman, 2008; Greenough et al., } \\
\text { 2013; Li et al., 2017; Bagheri et al., 2018; Liu et al., } \\
\text { 2019; Mocanu et al., 2020; Cilliers, 2021; } \\
\text { Anomalous concentration levels of metals in metal- } \\
\text { binding proteins have growth inhibition functions on } \\
\text { neurons - Constantinidis, 1991; Richarz and Brätter, } \\
\text { 2002; Trace metals and abnormal metal metabolism } \\
\text { influence protein aggregation, synaptic signalling } \\
\text { pathways, mitochondrial function, oxidative stress } \\
\text { levels, and inflammation, ultimately resulting in } \\
\text { synapse dysfunction and neuronal loss in the AD } \\
\text { brain - De Benedictis et al., 2019; Wang et al., } 2020\end{array}$ & $\begin{array}{l}\text { Air pollution, cf., long- } \\
\text { term exposure to } \mathrm{O}_{3} \\
\text { and } \mathrm{PM}_{2.5} \text { above the } \\
\text { current [2015] US EPA } \\
\text { standards (US EPA, } \\
\text { 2021) are associated } \\
\text { with increased the risk } \\
\text { of AD - Jung et al., } \\
\text { 2015; Association } \\
\text { between high altitude } \\
\text { exposure, cognitive } \\
\text { decline and dementia } \\
\text { mortality rate - Thielke } \\
\text { et al., 2015; Hu et al., } \\
\text { 2016; Lall et al., } \\
\text { 2019; Koester- } \\
\text { Hegmann et al., 2019; } \\
\text { Calderón-Garcidueñas, } \\
\text { 2021; Associations with } \\
\text { seasonal temperature - } \\
\text { Wei et al., 2019; Global } \\
\text { warming and } \\
\text { neurodegenerative } \\
\text { disorders - Habibi et } \\
\text { al., 2014 }\end{array}$ & $\begin{array}{l}\text { "Environmental risk } \\
\text { factors for Alzheimer } \\
\text { dementia are not well } \\
\text { understood" (Thielke } \\
\text { et al., 2015), nor are } \\
\text { those having links } \\
\text { with the geological } \\
\text { milieu. } \\
\text { In } 2019 \text { Alzheimer's } \\
\text { Disease International } \\
\text { (ADI) } \\
\text { estimated that there } \\
\text { are over } 50 \text { million } \\
\text { people living with } \\
\text { dementia globally, a } \\
\text { figure set to increase } \\
\text { to } 152 \text { million by 2050 } \\
\text { - ADI, 2019. In both } \\
\text { developed and } \\
\text { developing nations, } \\
\text { Alzheimer's disease } \\
\text { has had tremendous } \\
\text { impact on the affected } \\
\text { individuals, } \\
\text { caregivers, and } \\
\text { society [See, e.g., } \\
\text { Taylor et al. (2017), } \\
\text { for some relatively } \\
\text { recent figures for } \\
\text { Alzheimer's mortality } \\
\text { in the US). } \\
\text { Because developing } \\
\text { countries are } \\
\text { projected to see the } \\
\text { largest increase in } \\
\text { absolute numbers of } \\
\text { older persons, their } \\
\text { share of the } \\
\text { worldwide aging } \\
\text { population will } \\
\text { increase from } 59 \% \text { to } \\
71 \% \text { - Qui et al, 2009. } \\
\text { "Because occurrence } \\
\text { of AD is strongly } \\
\text { associated with } \\
\text { increasing age, it is } \\
\text { anticipated that this } \\
\text { dementing disorder } \\
\text { will pose huge } \\
\text { challenges to public } \\
\text { health and elderly } \\
\text { care systems in all } \\
\text { countries across the } \\
\text { world" - Qui et al, } \\
\text { 2009 } \\
\end{array}$ \\
\hline $\begin{array}{l}\text { 5. Autism } \\
\text { Spectrum } \\
\text { Disorder }\end{array}$ & $\begin{array}{l}\text { Autism Spectrum } \\
\text { Disorder (ASD) refers to a } \\
\text { diverse group of } \\
\text { developmental conditions } \\
\text { caused by differences in the } \\
\text { brain, and is characterised by } \\
\text { some degree of impaired }\end{array}$ & $\begin{array}{l}\text { Worldwide prevalence. } \\
\text { About } 1 \text { in } 160 \text { children } \\
\text { have ASD - Elsabbagh et al., } \\
\text { 2012; A geographical } \\
\text { pattern is observed in ASD } \\
\text { prevalence study in the US - } \\
\text { Hoffman et al., 2017. ASD }\end{array}$ & $\begin{array}{l}\text { Several environmental factors mentioned in the } \\
\text { development of ASD, include: air pollutants, } \\
\text { fragrances, glyphosate and toxic metals, especially } \\
\text { Al used in vaccines as adjuvant - Sealey et al., 2016; } \\
\text { Existence of mechanistic link between genetic } \\
\text { mutations in Shank proteins and Zn deficiency in the } \\
\text { aetiology of ASD - Ha et al., 2018; Significantly }\end{array}$ & $\begin{array}{l}\text { Season of birth as a } \\
\text { risk factor for ASD - } \\
\text { Lee et al., } 2019\end{array}$ & - \\
\hline
\end{tabular}




\begin{tabular}{|c|c|c|c|c|c|}
\hline & $\begin{array}{l}\text { social behaviours, speech and } \\
\text { nonverbal communication }\end{array}$ & $\begin{array}{l}\text { certainly prevalent in } \\
\text { Africa, but prevalence rate } \\
\text { is unknown, e.g., for South } \\
\text { Africa - See: Pillay et al., } \\
2021 \text {; and, by 2021, very } \\
\text { little research has been } \\
\text { done within the school } \\
\text { systems in South Africa }\end{array}$ & 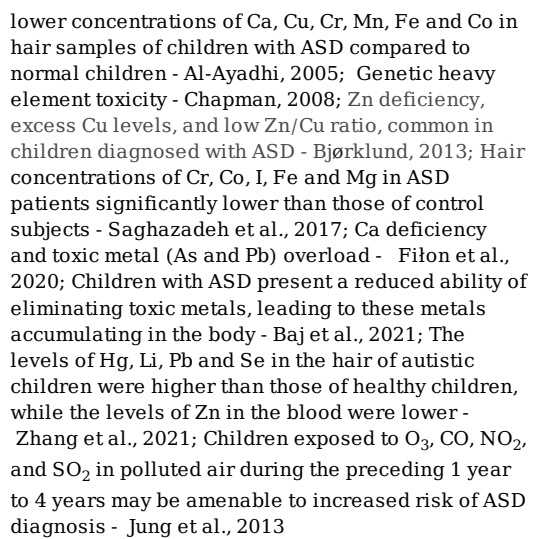 & & \\
\hline $\begin{array}{l}\text { 6. Chronic Fatigue } \\
\text { Syndrome/Myalgic } \\
\text { Encephalomyelitis }\end{array}$ & $\begin{array}{l}\text { Chronic Fatigue } \\
\text { Syndrome/Myalgic } \\
\text { Encephalomyelitis (CFS/ME) } \\
\text { is a disabling, debilitating and } \\
\text { complex disease } \\
\text { characterised by profound } \\
\text { fatigue, sleep abnormalities, } \\
\text { pain and other symptoms that } \\
\text { are worsened by exertion }\end{array}$ & $\begin{array}{l}\text { Worldwide prevalence } \\
\text { (Panelli, 2017; Lim et al., } \\
\text { 2020), with } 17 \text { to } 24 \text { million } \\
\text { people having the disease } \\
\text { (EME CFS, 2020) }\end{array}$ & $\begin{array}{l}\text { Metal hypersensitivity - Manousek et al., 2014; } \\
\text { Some nutrient deficiencies (vitamin C, vitamin B } \\
\text { complex, Na, Mg, Zn, folic acid, L-carnitine, L- } \\
\text { tryptophan, essential fatty acids, and coenzyme Q10) } \\
\text { appear to be important in the severity and } \\
\text { exacerbation of CFS - Bjørklund et al., 2019; Ca } \\
\text { associated with some of the neurological findings } \\
\text { described in ME/CFS - Pacini et al., 2012; } \\
\text { Insufficient Ca inflow into cells that perform } \\
\text { intracellular functions - Nguyen et al., } 2017\end{array}$ & - & $\begin{array}{l}\text { "Researchers have } \\
\text { not yet found } \\
\text { what causes ME/CFS, } \\
\text { and there are no } \\
\text { specific laboratory } \\
\text { tests to diagnose } \\
\text { ME/CFS directly" - } \\
\text { US CDC, 2018. It } \\
\text { cannot be fully } \\
\text { explained by an } \\
\text { underlying medical } \\
\text { condition. } \\
\text { "There is a need for } \\
\text { more epidemiologic } \\
\text { studies on the } \\
\text { prevalence and } \\
\text { sociodemographic } \\
\text { characteristics of CFS } \\
\text { in developing } \\
\text { countries." - Njoku et } \\
\text { al., 2007. } \\
\text { Sierpina and Carter } \\
\text { (2002) suggested that } \\
\text { 200 mcg of chromium } \\
\text { picolinate (taken with } \\
\text { meals) may have the } \\
\text { potential to reduce } \\
\text { any reactive } \\
\text { hypoglyca emia that } \\
\text { may aggravate } \\
\text { symptoms }\end{array}$ \\
\hline $\begin{array}{l}\text { 7. Chronic Kidney } \\
\text { Disease of } \\
\text { Unknown } \\
\text { Aetiology }\end{array}$ & $\begin{array}{l}\text { Chronic Kidney Disease of } \\
\quad \text { unknown aetiology (CKDu) } \\
\text { has, as its predominant } \\
\text { feature, tubular atrophy and } \\
\text { interstitial fibrosis (thickening } \\
\text { and scarring of the tiny air } \\
\text { sacs and interstitial tissues in } \\
\text { the lungs) }\end{array}$ & $\begin{array}{l}\text { Reported in many parts of } \\
\text { the world, especially among } \\
\text { rural farming communities. } \\
\text { High incidence in low- and } \\
\text { middle-income countries } \\
\text { over last two decades - } \\
\text { Mills et al., 2015; Bikbov et } \\
\text { al., 2020; "In 2017, } \\
\text { the global prevalence of } \\
\text { Chronic Kidney Disease } \\
\text { (CKD) was } 9.1 \% \text { (95\% } \\
\text { uncertainty interval [UI] } 8.5 \\
\text { to 9.8), which is roughly } 700 \\
\text { million cases" - Cockwell } \\
\text { and Fisher, } 2020\end{array}$ & $\begin{array}{l}\text { Synergistic reaction between Cd and diabetic- } \\
\text { related hyperglycaemia - Edwards and Prozialeck, } \\
\text { 2009; Consumption of (polluted) well water } \\
\text { suggested; need for investigating role of Cd - } \\
\text { Wanigasuriya et al., 2011; Too high Ca intake? - } \\
\text { Schiffrin et al., 2007; "Geographical mapping } \\
\text { showed that villages with a high prevalence of CKDu } \\
\text { are often related to irrigation water sources and/or } \\
\text { located below the level of the water table" } \\
\text { (Jayasekara et al., 2013); Toxins/heavy metals - Jha } \\
\text { et al., 2013; Groundwater geochemistry (high levels } \\
\text { of F-, Cd, As) - Wijetunge et al., 2015; Exposure to } \\
\text { low levels of Cd - Redmon et al., 2014; High ionicity } \\
\text { of drinking water due to fertiliser runoff - Dharma- } \\
\text { Wardana et al., 2015; Rajapakse et al., 2016; Toxic } \\
\text { metal exposure; water pollution - Lunyera et al., } \\
\text { 2016; Synergistic reaction between fluoride and } \\
\text { water hardness - Sengupta, 2013; } \\
\text { Wickramarathna et al., 2017; Balasooriya et al., } \\
\text { 2020; Chemical species such as Ca, phosphate, } \\
\text { oxalate, and F- form intra-renal nanomineral } \\
\text { particles initiating the CKD of multifactorial origin } \\
\text { (CKDmfo) - Wimalawansa and Dissanayake, 2020; } \\
\text { Total dissolved solids and As in drinking water have } \\
\text { a positive correlation with CKDu - Gobalarajah et al., } \\
\text { 2020 }\end{array}$ & $\begin{array}{l}\text { Altitude - Almaguer et } \\
\text { al., 2014; Heat stress } \\
\text { nephropathy due to } \\
\text { global warming - } \\
\text { Glaser et al., } \\
\text { 2016; Sorensen and } \\
\text { Garcia-Trabanino, } \\
\text { 2019; Floris et al., } \\
\text { 2021; Climatic patterns } \\
\text { - Wimalawansa and } \\
\text { Dissanayake, 2020; A } \\
\text { quintessential climate- } \\
\text { sensitive disease - } \\
\text { Salas et al., } 2019\end{array}$ & $\begin{array}{l}\text { "There have been } \\
\text { several global } \\
\text { epidemics of CKDu. } \\
\text { Some, such as Itai-Itai } \\
\text { disease in Japan and } \\
\text { Balkan } \\
\text { endemic nephropathy, } \\
\text { have been explained, } \\
\text { whereas the aetiology } \\
\text { of others remains } \\
\text { unclear" - Gifford et } \\
\text { al., } 2017 \text {. "Those } \\
\text { affected do not have } \\
\text { common risk factors } \\
\text { or underlying } \\
\text { conditions that lead } \\
\text { to CKD, such as } \\
\text { diabetes, immune- } \\
\text { mediated } \\
\text { glomerulonephritis, } \\
\text { or structural renal } \\
\text { disease" - Caplin et } \\
\text { al., } 2019\end{array}$ \\
\hline $\begin{array}{l}\text { 8.Endomyocardial } \\
\text { fibrosis }\end{array}$ & $\begin{array}{l}\text { Endomyocardial } \\
\text { Fibrosis (EMF) is a form of } \\
\text { restrictive cardiomyopathy of } \\
\text { unknown aetiology, } \\
\text { characterised by endocardial } \\
\text { fibrosis of the apices and } \\
\text { inflow tracts of the right } \\
\text { ventricle, left ventricle or both } \\
\text { (Khalil, 2020) }\end{array}$ & $\begin{array}{l}\text { Most prevalent in the } \\
\text { tropical regions of Africa, } \\
\text { Asia, and South America, } \\
\text { and mainly affecting young } \\
\text { adults of lower } \\
\text { socioeconomic status in } \\
\text { those regions }\end{array}$ & $\begin{array}{l}\text { Significantly elevated Ce levels }(\rho<0.05) \text { in serum } \\
\text { of EMF patients compared to controls - Eapen et al., } \\
\text { 1997; Ce contamination in soil and water - Bhatti et } \\
\text { al. 2021; High levels of Ce; Deficiency of Mg } \\
\text { promotes the absorption of Ce and enhances its } \\
\text { toxicity forming the basis for the initial injury of the } \\
\text { heart (Smith etal., 1998; Thakaran and Bohora, } \\
\text { 2009; Mocumbi etal., 2019) }\end{array}$ & - & $\begin{array}{l}\text { In 2014, Mocumbi } \\
\text { wrote: "EMF is } \\
\text { probably the most } \\
\text { neglected disease in } \\
\text { cardiovascular } \\
\text { medicine. Despite } \\
\text { constituting a big } \\
\text { burden to the families } \\
\text { and health systems in } \\
\text { endemic areas, due to } \\
\text { its preponderance in } \\
\text { poor sectors of the } \\
\text { society, few human } \\
\text { and material } \\
\text { resources are made } \\
\text { available for research } \\
\text { onto its mechanisms." }\end{array}$ \\
\hline
\end{tabular}




\begin{tabular}{|c|c|c|c|c|c|}
\hline & & & & & $\begin{array}{l}\text { Today (2021), the } \\
\text { exact aetiology and } \\
\text { pathogenesis of EMF } \\
\text { remains unknown } \\
\text { (See e.g., Bhatti et al., } \\
\text { 2021; Khalil, } 2020\end{array}$ \\
\hline 9. Fibromyalgia & $\begin{array}{l}\text { Fibromyalgia is a rheumatic } \\
\text { condition characterised by } \\
\text { chronic pain, fatigue, and } \\
\text { tenderness of muscles, } \\
\text { tendons, and joints; often } \\
\text { accompanied by fatigue, sleep, } \\
\text { memory and mood issues }\end{array}$ & $\begin{array}{l}\text { Fibromyalgia has a } \\
\text { worldwide prevalence } \\
\text { ranging from } 0.2 \% \text { to } 6.6 \% \\
\text { in the general population; } \\
\text { in women between } 2.4 \text { and } \\
6.8 \% \text {; in urban areas } \\
\text { between } 0.7 \text { and } 11.4 \% \text { in } \\
\text { rural areas (Marques et al., } \\
2017 \text { ) }\end{array}$ & $\begin{array}{l}\text { An imbalance of the trace element status in human } \\
\text { tissues and body fluids - Rosborg et al., 2007; } \\
\text { Sendur et al., 2008; Metal-induced oxidative stress } \\
\text { contributes to the severity of FMS (Stejskal et al., } \\
\text { 2013; Shukla et al., 2021); Elevated blood Pb and Cd } \\
\text { levels in FMS patients, compared with control } \\
\text { group; Serum Ca and Mg levels significantly } \\
\text { reduced ( } \rho \text { < 0.05) in FMS patients compared to } \\
\text { control group - Al-Khalifa et al., 2016; Women with } \\
\text { FM have lower dietary intake of Ca, Mg, Fe and Mn } \\
\text { in comparison with women who did not have the } \\
\text { condition - Kim et al., 2011; Andretta et al., } 2019\end{array}$ & $\begin{array}{l}\text { Fors and Sexton's } 2002 \\
\text { study did not reveal any } \\
\text { statistically significant } \\
\text { relationship between } \\
\text { fibromyalgic pain and } \\
\text { the weather, although it } \\
\text { is possible that certain } \\
\text { patients with less } \\
\text { chronic fibromyalgia } \\
\text { might be weather } \\
\text { sensitive }\end{array}$ & $\begin{array}{l}\text { The aetiology and } \\
\text { pathogenesis of } \\
\text { fibromyalgia till today } \\
\text { (2021), remain a } \\
\text { mystery. Several } \\
\text { proposed co-factors } \\
\text { such as dysfunction of } \\
\text { the central and } \\
\text { autonomic nervous } \\
\text { systems, } \\
\text { neurotransmitters, } \\
\text { hormones, immune } \\
\text { system, external } \\
\text { stressors, psychiatric } \\
\text { aspects, and others } \\
\text { are still being } \\
\text { researched (See e.g., } \\
\text { Siracusa et al., 2021). } \\
\text { The recent literature } \\
\text { clearly shows that the } \\
\text { role of the } \\
\text { metallome in FMS } \\
\text { aetiology deserves } \\
\text { far more attention }\end{array}$ \\
\hline $\begin{array}{l}\text { 10. Geographic } \\
\text { Tongue }\end{array}$ & $\begin{array}{l}\text { Geographic tongue (also } \\
\text { known as benign migratory } \\
\text { glossitis) is an inflammatory } \\
\text { disorder that usually } \\
\text { appears in a map-like } \\
\text { (geographic) pattern on the } \\
\text { dorsum and margins of the } \\
\text { tongue. Typically, } \\
\text { affected tongues have a bald, } \\
\text { red area of varying sizes that } \\
\text { is surrounded, at least in part, } \\
\text { by an irregular white border }\end{array}$ & $\begin{array}{l}\text { A common condition, } \\
\text { affecting } 2-3 \% \text { of the adult } \\
\text { general } \\
\text { population, worldwide (Ship } \\
\text { et al. 2003; Picciani et al., } \\
\text { 2020) }\end{array}$ & $\begin{array}{l}\text { Fe and Zn deficiency; Vitamin B12 - Ogueta et al., } \\
\text { 2019; Nandini et al., 2016; Picciani et al., 2016; } \\
\text { Picciani et al., 2017; Low levels of salivary Zn in } \\
\text { affected individuals compared to control groups - } \\
\text { Khayamzadeh et al., } 2019\end{array}$ & - & - \\
\hline $\begin{array}{l}\text { 11. Ill-thrift or } \\
\text { 'Unthriftiness' as it } \\
\text { is called in South } \\
\text { Africa }\end{array}$ & $\begin{array}{l}\text { Ill-thrift or Unthriftiness is } \\
\text { an ill-defined condition of } \\
\text { young sheep. Affected animals } \\
\text { show mild to severe } \\
\text { depression of growth rate and } \\
\text { anaemia }\end{array}$ & $\begin{array}{l}\text { In South Africa, the disease } \\
\text { occurs in the coastal areas } \\
\text { of the Eastern Cape } \\
\text { Province. The condition has } \\
\text { been reported from a } \\
\text { number of other countries, } \\
\text { including Australia, New } \\
\text { Zealand, France and } \\
\text { Norway (Stewart and } \\
\text { Burroughs, Undated) }\end{array}$ & $\begin{array}{l}\mathrm{Cu} \text {, Co, Se and I, being essential components of the } \\
\text { diet of beef cattle for maintaining their health and } \\
\text { productivity, their deficiency in these elements can } \\
\text { cause ill-thrift and infertility, among other causes - } \\
\text { Crawshaw and Caldow, 2005; A state of sub-optimal } \\
\text { growth (ill-thrift) in buffalo-calves was largely } \\
\text { attributed to trace element deficiency, in particular } \\
\mathrm{Cu}, \mathrm{Co}, \mathrm{Fe} \text {, Se and Zn deficiency that may cause } \\
\text { reduction in the total antioxidant capacity, with a } \\
\text { lower ability to reduce oxidative compounds - Ali et } \\
\text { al., 2015; Ismael et al., 2015; MLA, 2020 }\end{array}$ & $\begin{array}{l}\text { Mainly reported from } \\
\text { coastal areas of high } \\
\text { rainfall - Examples are } \\
\text { found in Australia } \\
\text { (MLA, 2020) and South } \\
\text { Africa (Stewart and } \\
\text { Burroughs, Undated) }\end{array}$ & - \\
\hline $\begin{array}{l}\text { 12. Kawasaki } \\
\text { Disease }\end{array}$ & $\begin{array}{l}\text { Kawasaki Disease (KD) is an } \\
\text { acute, self-limited vasculitis } \\
\text { (inflamed blood vessels) of } \\
\text { infants and children, with } \\
\text { unknown aetiology. } \\
\text { Signs of KD include prolonged } \\
\text { fever associated with rash, red } \\
\text { eyes, mouth, lips and tongue, } \\
\text { and swollen hands and feet } \\
\text { with peeling skin. The disease } \\
\text { causes damage to the } \\
\text { coronary arteries in a quarter } \\
\text { of untreated children and may } \\
\text { lead to serious heart problems } \\
\text { in early adulthood }\end{array}$ & $\begin{array}{l}\text { KD occurs worldwide; most } \\
\text { prominently in Japan, Korea, } \\
\text { and Taiwan, reflecting } \\
\text { increased genetic } \\
\text { susceptibility among Asian } \\
\text { populations (Rowley and } \\
\text { Shulman, 2018). } \\
\text { The epidemiology of KD in } \\
\text { Africa is very ill-defined, } \\
\text { which inevitably leads to } \\
\text { misdiagnosis and the } \\
\text { reporting of very few cases. } \\
\text { This gives the impression } \\
\text { that the condition is rare in } \\
\text { Africa - Badoe et al., 2011; } \\
\text { Animasahun et al., 2017; } \\
\text { Noorani and Lakhani, 2018. } \\
\text { The presentation of KD is } \\
\text { similar to that of measles } \\
\text { (which is very prevalent in } \\
\text { Africa), so the exact } \\
\text { prevalence (of KD in Africa) } \\
\text { is difficult to ascertain - See } \\
\text { e.g., Badoe et al., 2011; } \\
\text { Davaalkham et al., 2011 }\end{array}$ & $\begin{array}{l}\text { Environmental exposure to Hg - Orlowski and } \\
\text { Mercer, 1980; Mutter and Yeter, 2008; Yeter et al., } \\
\text { 2016; Portman et al., 2018; Airborne pathogens or } \\
\text { toxins - Rodo et al., 2014; Rodo et al., } 2016\end{array}$ & $\begin{array}{l}\text { Seasonality of KD, with } \\
\text { winter peaks and } \\
\text { winter-spring } \\
\text { predominance in Japan } \\
\text { and the US, } \\
\text { respectively, and in } \\
\text { many other temperate } \\
\text { areas - Rowley and } \\
\text { Shulman, 2018; } \\
\text { Decades of research } \\
\text { have been unable to } \\
\text { unearth the cause of } \\
\text { the disease, but its } \\
\text { distinct seasonality can } \\
\text { hardly be in doubt } \\
\text { - UCSDH, 2013; Lin and } \\
\text { Wu, 2017; Rypdal et al., } \\
\text { 2018; Kim, 2019; } \\
\text { Elakabawi et al., } 2020\end{array}$ & $\begin{array}{l}\text { (i) "... Thus, these } \\
\text { twin studies suggest } \\
\text { that environmental } \\
\text { factors contribute } \\
\text { more to the } \\
\text { development of KD } \\
\text { than genetic factors } \\
\text { among individuals } \\
\text { with the same } \\
\text { ethnicity." - Hara et } \\
\text { al., 2016. } \\
\text { (ii) The temporal } \\
\text { association between } \\
\text { the COVID-19 } \\
\text { pandemic and the } \\
\text { results of RT-PCR and } \\
\text { antibody testing } \\
\text { suggest a causal link } \\
\text { between Kawasaki } \\
\text { disease and COVID- } \\
\text { 19 - Toubiana et al., } \\
\text { 2020. } \\
\text { As Rowley and } \\
\text { Schulman remarked } \\
\text { in 2018, "The } \\
\text { occurrence of } \\
\text { epidemics and } \\
\text { geographic wave-like } \\
\text { spread of KD during } \\
\text { epidemics supports a } \\
\text { presently unknown } \\
\text { single agent or } \\
\text { closely related group } \\
\text { of agents as the } \\
\text { etiology." [Sic.] }\end{array}$ \\
\hline $\begin{array}{l}\text { 13. Lupus } \\
\text { Erythematosus }\end{array}$ & $\begin{array}{l}\text { Systemic Lupus } \\
\text { Erythematosus (SLE) is a } \\
\text { chronic inflammatory } \\
\text { autoimmune disease of } \\
\text { multifactorial origin (Pedro et } \\
\text { al., 2019) }\end{array}$ & $\begin{array}{l}\text { Worldwide. Highest } \\
\text { prevalence rate in North } \\
\text { America (Rees et al., 2017). } \\
\text { Once thought to be of low } \\
\text { prevalence rate in Sub- } \\
\text { Saharan Africa (due to }\end{array}$ & $\begin{array}{l}\text { Low serum levels of albumin, } \mathrm{Zn}, \mathrm{Se} \text { and } \mathrm{Zn} / \mathrm{Cu} \\
\text { ratio; negative correlation between serum Cu levels } \\
\text { and lupus disease activity - Sahebari et al., 2014; } \\
\text { SLE patients have different profiles of trace } \\
\text { elements and toxic metals compared to healthy } \\
\text { controls - Pedro et al., } 2019\end{array}$ & $\begin{array}{l}\text { "Active SLE has the } \\
\text { characteristics of } \\
\text { seasonal distribution } \\
\text { and is associated with } \\
\text { temperature. The } \\
\text { mechanism remains to }\end{array}$ & $\begin{array}{l}\text { The aetiology of SLE } \\
\text { is complex, and } \\
\text { incompletely } \\
\text { understood } \\
\text { (See: Justiz Vaillant } \\
\text { et al. - Updated 2020). }\end{array}$ \\
\hline
\end{tabular}




\begin{tabular}{|c|c|c|c|c|c|}
\hline & & $\begin{array}{l}\text { under-reporting?) SLE } \\
\text { prevalence rate is now } \\
\text { found to } 1.7 \% \text { (Essouma et } \\
\text { al., 2020), as a result of } \\
\text { availability of improved } \\
\text { diagnostic capacity }\end{array}$ & & $\begin{array}{l}\text { be further studied" - } \\
\text { Hua-Li et al., } 2011\end{array}$ & $\begin{array}{l}\text { "More } \\
\text { epidemiological } \\
\text { studies in Africa are } \\
\text { warranted." - Rees et } \\
\text { al., } 2017\end{array}$ \\
\hline $\begin{array}{l}\text { 14. Multiple } \\
\text { Sclerosis }\end{array}$ & $\begin{array}{l}\text { Multiple Sclerosis (MS) is } \\
\text { a demyelinating disease (a } \\
\text { nervous system disease in } \\
\text { which the insulating covers of } \\
\text { nerve cells in the brain and } \\
\text { spinal cord are } \\
\text { damaged). This damage } \\
\text { disrupts the ability of parts of } \\
\text { the nervous system to transmit } \\
\text { signals, resulting in a range } \\
\text { of signs and symptoms, } \\
\text { including physical, mental, } \\
\text { and sometimes psychiatric } \\
\text { problems (Compston and } \\
\text { Coles, 2002; Compton and } \\
\text { Coles, 2008; Murray et al., } \\
\text { 2012). Kister et al. (2013) list } \\
11 \text { specific symptom domains } \\
\text { commonly affected in multiple } \\
\text { sclerosis: mobility, hand } \\
\text { function, vision, fatigue, } \\
\text { cognition, bowel/bladder } \\
\text { function, sensory, spasticity, } \\
\text { pain, depression, and } \\
\text { tremor/coordination }\end{array}$ & $\begin{array}{l}\text { Distribution is worldwide. } \\
\text { Distinct geographical } \\
\text { pattern of prevalence with } \\
\text { high prevalence rates } \\
\text { between } 45 \text { degrees and } 65 \\
\text { degrees north (Wade, } \\
2014 \text { ). } \\
\text { The age-standardised MS } \\
\text { prevalence estimate per } \\
100,000 \text { population for } \\
\text { eastern Sub-Saharan Africa } \\
\text { is put at } 3.3 \text { by WGBD } \\
\text { (2019); but such an } \\
\text { estimate would always be } \\
\text { influenced by misdiagnosis } \\
\text { and under-reporting (e.g., } \\
\text { Bhigjee et al., 2007) }\end{array}$ & $\begin{array}{l}\text { Metabolic imbalance of trace elements/metals - } \\
\text { Rieder et al., 1983; Smith et al., 1989; Melø et al., } \\
\text { 2003; Tamburo et al., 2015; Bredholt and } \\
\text { Frederikson, 2016; Janghorbani et al., 2017; } \\
\text { Sarmadi et al., 2020; the therapeutic potential of } \\
\text { antioxidant [reactive oxygen species (ROS)] } \\
\text { protection in the pathogenesis of MS - van Horssen } \\
\text { et al., 2011; Tavassolifar et al., 2020; Effect on the } \\
\text { immune system of Al toxicity and Cu, Zn, and Se } \\
\text { toxicity and deficiency, followed by neuron } \\
\text { inflammation and degeneration - Hesamian and } \\
\text { Eskandari, } 2020\end{array}$ & $\begin{array}{l}\text { People living in higher } \\
\text { geographical } \\
\text { latitudes may receive } \\
\text { lower levels of } \\
\text { sunlight, and therefore } \\
\text { have lower vitamin D } \\
\text { levels which probably } \\
\text { explains the reason for } \\
\text { a higher incidence of } \\
\text { MS in countries with } \\
\text { higher latitudes - MS } \\
\text { International } \\
\text { Federation, } \\
\text { 2016; "There is a } \\
\text { striking latitudinal } \\
\text { gradient in multiple } \\
\text { sclerosis (MS) } \\
\text { prevalence ..." - } \\
\text { Simpson Jnr. et al., } \\
\text { 2011, Simpson Jnr. et } \\
\text { al., 2019; See } \\
\text { also: Warren and } \\
\text { Warren, 2001; Staples } \\
\text { et al., 2003; Sabel et } \\
\text { al., 2021 }\end{array}$ & - \\
\hline $\begin{array}{l}\text { 15. Nodding } \\
\text { Disease } \\
\text { (ND)/Nodding } \\
\text { syndrome (NS) }\end{array}$ & $\begin{array}{l}\text { Nodding Disease is } \\
\text { characterised by an } \\
\text { occasional nodding of the } \\
\text { head, as in epilepsy, with } \\
\text { seizures, stunted growth, and } \\
\text { with mental } \\
\text { retardation sometimes } \\
\text { occurring }\end{array}$ & $\begin{array}{l}\text { This is an emerging disease } \\
\text { occurring in clusters in } \\
\text { South Sudan, southern } \\
\text { Tanzania, northern Uganda } \\
\text { and possibly also other } \\
\text { countries of Sub-Saharan } \\
\text { Africa. The exact prevalence } \\
\text { and geographic distribution } \\
\text { of the disease in the } \\
\text { affected countries is still } \\
\text { unknown - Korevaar and } \\
\text { Visser, } 2013\end{array}$ & $\begin{array}{l}\text { Deficiency of vitamin B6 (pyridoxine) and other } \\
\text { micronutrients such as vitamin A, Se, and Zn - } \\
\text { GU/WHO, 2012; Foltz et al., } 2013\end{array}$ & $\begin{array}{l}\text { Climate change - } \\
\text { Donnelly, 2012; Cold } \\
\text { weather - Kaiser et al., } \\
\text { 2000; Nyungura et al., } \\
\text { 2011; Living in the } \\
\text { vicinity of fast-flowing } \\
\text { streams, the breeding } \\
\text { habitat of the black fly - } \\
\text { Donnelly, } 2012\end{array}$ & $\begin{array}{l}\text { "Nutritional toxicity } \\
\text { remains a possible } \\
\text { cause of nodding } \\
\text { syndromes." - Dowell } \\
\text { et al., 2013. } \\
\text { As at 2020, "Much } \\
\text { about NS remains } \\
\text { unclear. That we do } \\
\text { not know the cause of } \\
\text { the disorder is } \\
\text { perhaps least } \\
\text { surprising - the } \\
\text { number of acquired } \\
\text { neurological diseases } \\
\text { whose a etiology is } \\
\text { well understood is not } \\
\text { large...." Olum et al. } \\
\text { (2020). }\end{array}$ \\
\hline 16. Noma & $\begin{array}{l}\text { Noma (cancrum oris or } \\
\text { gangrenous stomatitis), is a } \\
\text { severe and progressive } \\
\text { gangrenous infection (body } \\
\text { tissues die as a result of } \\
\text { infection or inadequate blood } \\
\text { supply) that affects the mouth } \\
\text { and face }\end{array}$ & $\begin{array}{l}\text { Mainly observed in tropical } \\
\text { countries, particularly those } \\
\text { in Sub-Saharan Africa. True } \\
\text { global incidence unknown; } \\
\text { but estimated incidence of } \\
30,000-40,000 \text { has been } \\
\text { suggested by Srour et al. } \\
\text { (2017) }\end{array}$ & $\begin{array}{l}\text { Deficiencies of trace elements and amino acids } \\
\text { influencing the efficacy of the immune system: Fe, } \\
\text { Zn, cysteine, methionine, serine, and glycine - } \\
\text { Baratti-Mayer et al., 2003; Deficiency of } \\
\text { micronutrients in the diet - Srour et al., 2017; Srour } \\
\text { and Baratti-Meyer, 2020; Farley et al., 2021 }\end{array}$ & - & $\begin{array}{l}\text { Patients generally } \\
\text { live in extremely poor } \\
\text { conditions, frequently } \\
\text { located in remote } \\
\text { rural areas }\end{array}$ \\
\hline $\begin{array}{l}\text { 17. Parkinson's } \\
\text { Disease }\end{array}$ & $\begin{array}{l}\text { Parkinson's Disease (PD) is a } \\
\text { progressive heterogeneous, } \\
\text { multisystem and } \\
\text { neurodegenerative nervous } \\
\text { system disorder that affects } \\
\text { movement. The cardinal } \\
\text { features of Parkinson's } \\
\text { disease are (i) tremor, mainly } \\
\text { at rest; (ii) muscular rigidity, } \\
\text { which leads to difficulties in } \\
\text { walking, writing, speaking and } \\
\text { masking of facial expression; } \\
\text { (iii) bradykinesia, a slowness } \\
\text { in initiating and executing } \\
\text { movements; and (iv) stooped } \\
\text { posture and instability (Sian } \\
\text { et al., 1999). } \\
\text { Parkinson's disease occurs } \\
\text { when nerve cells, or } \\
\text { dopamine-rich neurons in an } \\
\text { area of the brain that controls } \\
\text { movement called the } \\
\text { substantia nigra. become } \\
\text { impaired and/or die. But the } \\
\text { complete series of steps } \\
\text { leading to this cell death is } \\
\text { still vague, and the underlying } \\
\text { causes remain one of } \\
\text { medicine's greatest mysteries }\end{array}$ & $\begin{array}{l}\text { Worldwide occurrence. } \\
\text { According to the } 2016 \\
\text { Dorsey and GBD } \\
\text { Collaborators Study } \\
\text { published in } 2018,6 \cdot 1 \\
\text { million ( } 95 \% \text { uncertainty } \\
\text { interval [UI] 5.0 -7·3) } \\
\text { individuals had Parkinson's } \\
\text { disease globally, compared } \\
\text { with } 2 \cdot 5 \text { million (2.0 - 3.0) in } \\
\text { 1990; Geographical } \\
\text { variation (cf., latitude) plays } \\
\text { key role in dementia risk } \\
\text { (e.g., Russ et al., 2016) }\end{array}$ & $\begin{array}{l}\text { High concentrations of Al and low levels of Mg } \\
\text { observed in the pathogenesis of CNS (central } \\
\text { nervous system) degeneration and PD - Yasui et al., } \\
\text { 1992; Association with metal and trace element } \\
\text { concentration in urine, serum, whole blood and } \\
\text { cerebrospinal fluid - Bocca et al., 2004; Forte et al., } \\
\text { 2004; Gellein et al., 2008; Zhao et al., 2013; Raj et } \\
\text { al., 2021; Very high or very low levels of Se - } \\
\text { Ellwanger et al., 2016; Combination of Mo } \\
\text { deficiency and purine ingestion - Bourke, } \\
\text { 2018; Significant association between the PD } \\
\text { mortality rates and soil concentrations of Se, Sr, and } \\
\text { Mg - Sun, 2018; Adani et al., 2020; Lemelle et al., } \\
\text { 2020; Elevated trace metals (namely, Cu, Zn, Mg and } \\
\text { Fe) found compared to controls ( } \rho<0.001 \text { ) in } \\
\text { Nigerian Parkinson's Disease patients (Ogunrin et } \\
\text { al, } 2013\end{array}$ & $\begin{array}{l}\text { Existence } \\
\text { of seasonality (related } \\
\text { to temperature) in } \\
\text { Parkinson's disease } \\
\text { symptoms - Rowell et } \\
\text { al., 2017; Improvement } \\
\text { of PD symptoms at high } \\
\text { altitude - Capcha et al., } \\
\text { 2018; Thomas, 2019; } \\
\text { several risk factors in } \\
\text { development of PD at } \\
\text { high altitude - Cao et } \\
\text { al., } 2021\end{array}$ & $\begin{array}{l}\text { Regional maps } \\
\text { depicting correlations } \\
\text { between the } \\
\text { distribution (clusters) } \\
\text { of PD and soil } \\
\text { geochemistry which } \\
\text { would be helpful in } \\
\text { this aetiological } \\
\text { debate, are very rare } \\
\text { in the published } \\
\text { literature (See an } \\
\text { example in: Sun, 2018 } \\
\text { for PD distribution in } \\
\text { the United States). } \\
\\
\text { To date (2021), “... } \\
\text { the fundamental } \\
\text { molecular } \\
\text { mechanisms of PD } \\
\text { etiology and } \\
\text { pathogenesis is still } \\
\text { obscure, metals } \\
\text { toxicity have been } \\
\text { documented in the } \\
\text { implication of PD } \\
\text { pathogenesis by } \\
\text { several } \\
\text { epidemiological } \\
\text { studies with several } \\
\text { potential } \\
\text { mechanisms. In many } \\
\text { cases, the metals } \\
\text { equilibrium is } \\
\text { disturbed, which } \\
\text { leads to deleterious } \\
\text { effect on the entire } \\
\text { body including the }\end{array}$ \\
\hline
\end{tabular}




\begin{tabular}{|c|c|c|c|c|c|}
\hline & & & & & $\begin{array}{l}\text { brain." [Sic.] (Ullah } \\
\text { et al., 2021). }\end{array}$ \\
\hline 18. Sarcoidosis & $\begin{array}{l}\text { Sarcoidosis is a multisystem, } \\
\text { granulomatous, } \\
\text { inflammatory disease that } \\
\text { affects one or more organs, } \\
\text { but most commonly affects the } \\
\text { lungs and lymph glands. The } \\
\text { inflammation may change the } \\
\text { normal structure and possibly } \\
\text { the function of the affected } \\
\text { organ(s) }\end{array}$ & $\begin{array}{l}\text { Sarcoidosis is observed } \\
\text { throughout the world and } \\
\text { affects all races and } \\
\text { ages, with an average } \\
\text { incidence of } 16.5 \text { per } \\
100,000 \text { in men and } 19 \text { per } \\
100,000 \text { in women (Patil et } \\
\text { al., 2015). } \\
\text { Race and geographical } \\
\text { location are considered as } \\
\text { factors in the incidence and } \\
\text { prevalence of sarcoidosis, } \\
\text { which has consistently been } \\
\text { observed to be highest in } \\
\text { Nordic countries and in } \\
\text { African Americans (Arkema } \\
\text { and Cozier, 2018). } \\
\text { Sarcoidosis in not a rare } \\
\text { condition in Africa } \\
\text { (Awotedu et al., 1987; } \\
\text { Kaloga et al., 2015), the } \\
\text { apparent infrequency of } \\
\text { reporting being probably a } \\
\text { result of misdiagnosis (as, } \\
\text { e.g., tuberculosis) (Morar } \\
\text { and Feldman, 2015a; Morar } \\
\text { and Feldman, 2015b). } \\
\text { Further research is } \\
\text { therefore necessary in } \\
\text { Africa to unravel the various } \\
\text { clinical aspects of this } \\
\text { mysterious and complex } \\
\text { disease }\end{array}$ & $\begin{array}{l}\text { Exposure to toxic metals and rare earth elements } \\
\text { (REEs) in the environment - Newman, 1998; Beijer } \\
\text { et al., 2020; Denisova et al., 2020; Metal dusts - } \\
\text { Judson, 2020; Crystalline silica - Arkema and Cozier, } \\
\text { 2018; Industrial exposure to Be - Culver et al., 2007. } \\
\text { Since low dose metal particles can induce } \\
\text { monocyte/macrophage survival (See e.g., Lacey et } \\
\text { al., 2009), as recently as 2021, Lepzien et al. (2021) } \\
\text { went on to show that monocytes could be a vital } \\
\text { marker in understanding the inflammatory process } \\
\text { of sarcoidosis. }\end{array}$ & $\begin{array}{l}\text { Geographic clustering } \\
\text { of disease in many } \\
\text { parts of the world has } \\
\text { long been noted [e.g., } \\
\text { in the US (Sartwell and } \\
\text { Edwards, 1974)], and } \\
\text { has ignited further } \\
\text { speculations } \\
\text { concerning weather, } \\
\text { soil, and foliage in the } \\
\text { pathogenesis of } \\
\text { sarcoidosis. } \\
\text { More recently } \\
\text { (2019), Ramos-Casals } \\
\text { et al. asserted that } \\
\text { local weather is a key } \\
\text { environmental factor } \\
\text { influencing the } \\
\text { incidence of } \\
\text { sarcoidosis in a } \\
\text { specific geographical } \\
\text { area, with the peak of } \\
\text { diagnosed cases } \\
\text { following a specific } \\
\text { seasonal distribution } \\
\text { pattern }\end{array}$ & $\begin{array}{l}\text { The causes of } \\
\text { sarcoidosis are still } \\
\text { unknown and } \\
\text { epidemiological data } \\
\text { are often discordant } \\
\text { (Pietra et al., } \\
\text { 1988; Beghè et al., } \\
\text { 2017). } \\
\text { "Although the } \\
\text { etiology of this } \\
\text { condition is unclear, } \\
\text { environmental and } \\
\text { genetic factors may } \\
\text { be substantial in its } \\
\text { pathogenesis." [Sic.] } \\
\text { - Ganeshan et al., } \\
\text { 2018. } \\
\text { According to } \\
\text { Ahmadzai et al. } \\
\text { (2013), in } \\
\text { sarcoidosis, } \\
\text { conventional } \\
\text { sampling techniques } \\
\text { or cultures of non- } \\
\text { caseating granulomas } \\
\text { cannot detect tissue } \\
\text { micro-organisms; } \\
\text { although as Newman } \\
\text { earlier (1998) } \\
\text { proposed, clinicians } \\
\text { should use a } \\
\text { systematic approach } \\
\text { to investigating the } \\
\text { occupational and } \\
\text { environmental history } \\
\text { and immunologic } \\
\text { responses of patients } \\
\text { with sarcoidosis, for } \\
\text { discriminating metal- } \\
\text { induced } \\
\text { granulomatosis from } \\
\text { sarcoidosis } \\
\text { ando }\end{array}$ \\
\hline $\begin{array}{l}\text { 19. Spastic } \\
\text { Paraparesis }\end{array}$ & $\begin{array}{l}\text { Hereditary Spastic } \\
\text { Paraparesis (HSP) or the } \\
\text { Strüpell-Lorrain Syndrome } \\
\text { refers to a heterogeneous } \\
\text { group of disorders in which } \\
\text { the main clinical feature is } \\
\text { progressive lower limb } \\
\text { spasticity or gait disorder. } \\
\text { HSP is also known as familial } \\
\text { spastic paraplegia (US } \\
\text { NINDS, } \\
\text { 2014); however, "paraparesis" } \\
\text { indicates weakness in both } \\
\text { legs, and is of lesser severity } \\
\text { than "paraplegia" }\end{array}$ & $\begin{array}{l}\text { The prevalence of all } \\
\text { hereditary spastic } \\
\text { paraplegias combined is } \\
\text { estimated to be } 2 \text { to } 6 \text { in } \\
100,000 \text { people (US NIH, } \\
2019 \text { ) }\end{array}$ & $\begin{array}{l}\text { Nutritional disorders, including Cu deficiency, } \\
\text { vitamins } \mathrm{B}_{12} \text { and } \mathrm{E} \text { deficiencies - Mitchell et al., } \\
\text { 1986; Hedera, 2016; Hedera, } 2018\end{array}$ & $\begin{array}{l}\text { High intake of } \\
\text { HCN }^{-} \text {engendered } \\
\text { by drought conditions } \\
\text { (Cliff et al., 1984) }\end{array}$ & $\begin{array}{l}\text { See Taibo et al. } \\
\text { (2017) for report of a } \\
\text { real-life outbreak of } \\
\text { spastic paraparesis } \\
\text { investigation } \\
\text { undertaken in } \\
\text { northern Mozambique } \\
\text { in } 1981\end{array}$ \\
\hline $\begin{array}{l}\text { 20. Sudden Infant } \\
\text { Death Syndrome }\end{array}$ & $\begin{array}{l}\text { Sudden Infant Death } \\
\text { Syndrome (SIDS) is the } \\
\text { sudden and unexplained death } \\
\text { of a baby younger than } 1 \text { year } \\
\text { old, after thorough case } \\
\text { investigation (Duncan and } \\
\text { Byard, 2018) }\end{array}$ & $\begin{array}{l}\text { Global distribution (Müller- } \\
\text { Nordhorn et al., 2020); A } \\
\text { significant cause of } \\
\text { mortality in Africa (See: } \\
\text { Ogbu, 2003; Ndu, 2016; } \\
\text { Dempers et al., 2018) }\end{array}$ & $\begin{array}{l}\text { Genetic heavy element toxicity - Chapman, 2008; } \\
\text { Elevated Pb burden (blood samples) in SID babies } \\
\text { compared with control babies - Drasch et al., 1988; } \\
\text { Increased tissue Pb levels in SIDS infants - Erickson } \\
\text { et al., 1983; K levels significantly lower in less than } \\
\text { 6-month-old SIDS infants than in non-SIDS infants - } \\
\text { Steele et al., 1984; Soft water with low Mg and Ca } \\
\text { and with high concentration of Na, linked to higher } \\
\text { SIDS rates - Caddell, 1992; Recharge of } \\
\text { groundwater which increases its nitrate content - } \\
\text { George et al., } 2001\end{array}$ & $\begin{array}{l}\text { Cold wet weather - } \\
\text { Deacon and Williams, } \\
\text { 1982; Overheating or } \\
\text { disordered } \\
\text { thermoregulation - } \\
\text { Sawczenko and } \\
\text { Fleming, 1996; } \\
\text { Exposure to increased } \\
\text { ambient } \\
\text { temperature associated } \\
\text { with an increased risk } \\
\text { of SIDS - Schluter et } \\
\text { al., 1998; Jhun et al., } \\
2017\end{array}$ & $\begin{array}{l}\text { "Despite decades of } \\
\text { investigation and } \\
\text { millions of dollars } \\
\text { spent, the cause of } \\
\text { sudden infant death } \\
\text { syndrome (SIDS) } \\
\text { eludes researchers. It } \\
\text { is timely therefore to } \\
\text { reconsider the } \\
\text { reasons for this } \\
\text { failure and to explore } \\
\text { how research might } \\
\text { go forward with better } \\
\text { prospects." [Sic.] } \\
\text { (Goldwater, 2017). } \\
\text { In deciphering the } \\
\text { causes of SIDS, we } \\
\text { must remember that a } \\
\text { baby's immune } \\
\text { system is immature } \\
\text { when they are born, } \\
\text { making newborns } \\
\text { particularly at risk of } \\
\text { illness (See e.g., } \\
\text { Goenka and } \\
\text { Kollmann, 2015; } \\
\text { Simon et al., 2015). It } \\
\text { is therefore critically } \\
\text { important that their }\end{array}$ \\
\hline
\end{tabular}




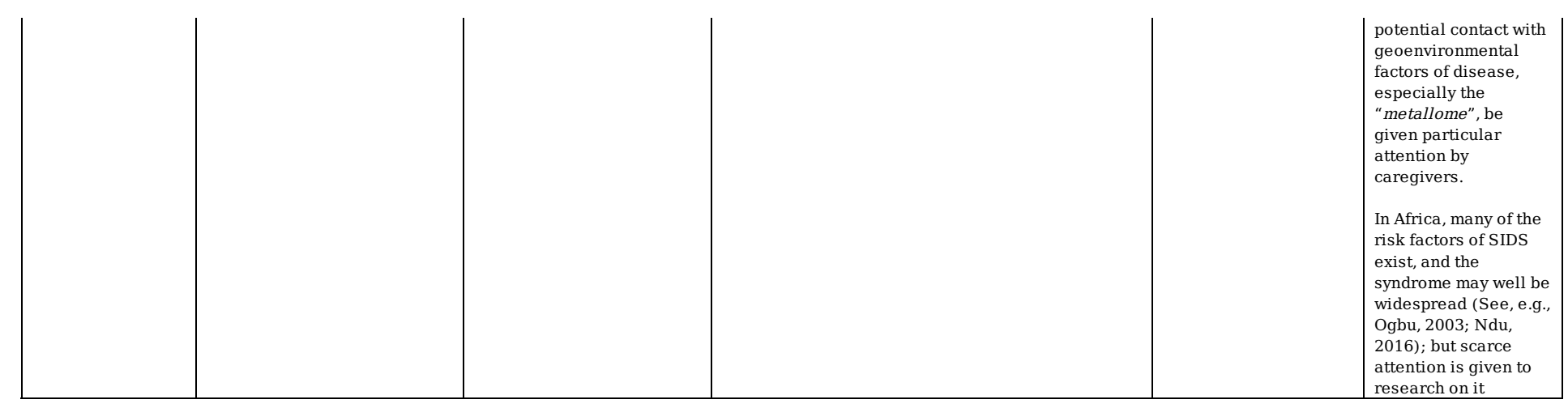
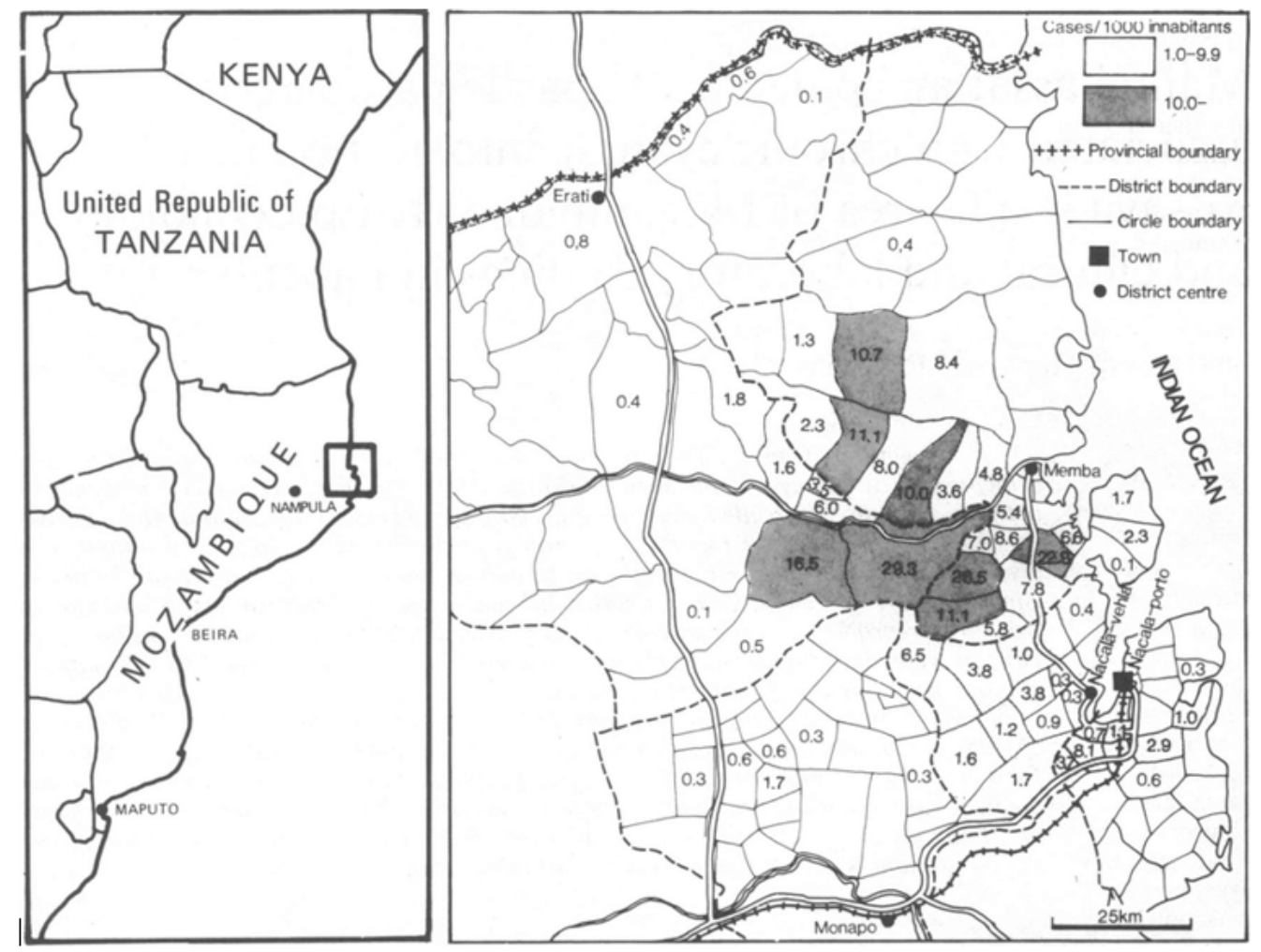

Figure 2

Map of Mozambique, showing the affected area and incidence rates of "mantakassa" (spastic paraparesis) per 1000 inhabitants. Source: Reproduced from Cliff et al., 1984. 


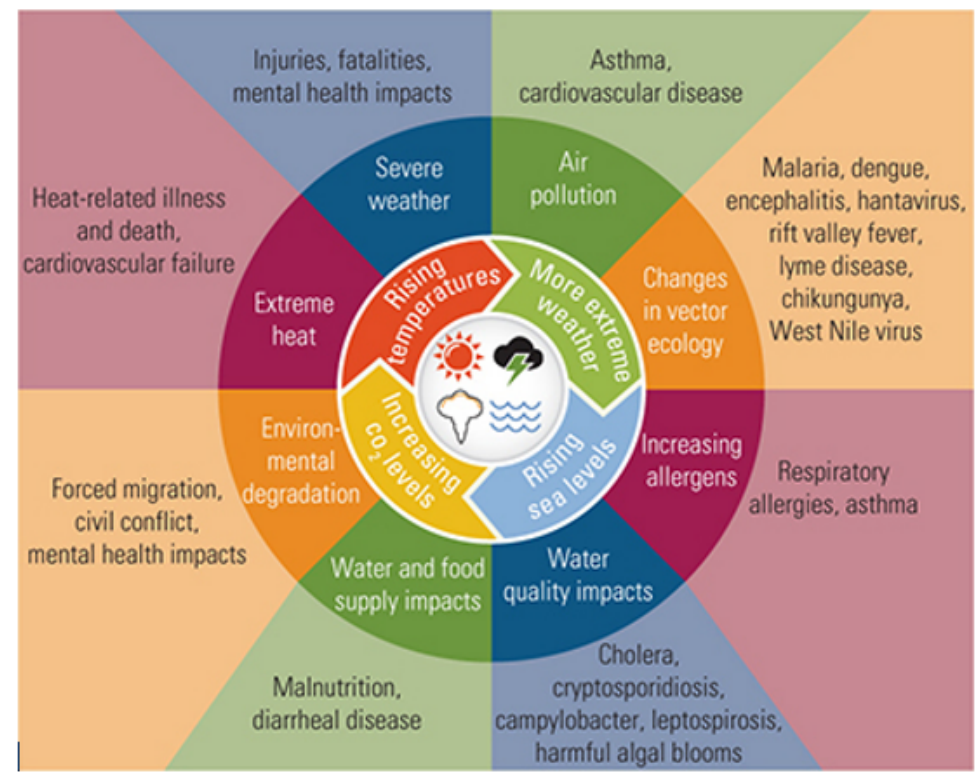

Figure 3

Impact of climate change on human health. Credit: George Luber, CDC. Source: Ebi et al., 2017.

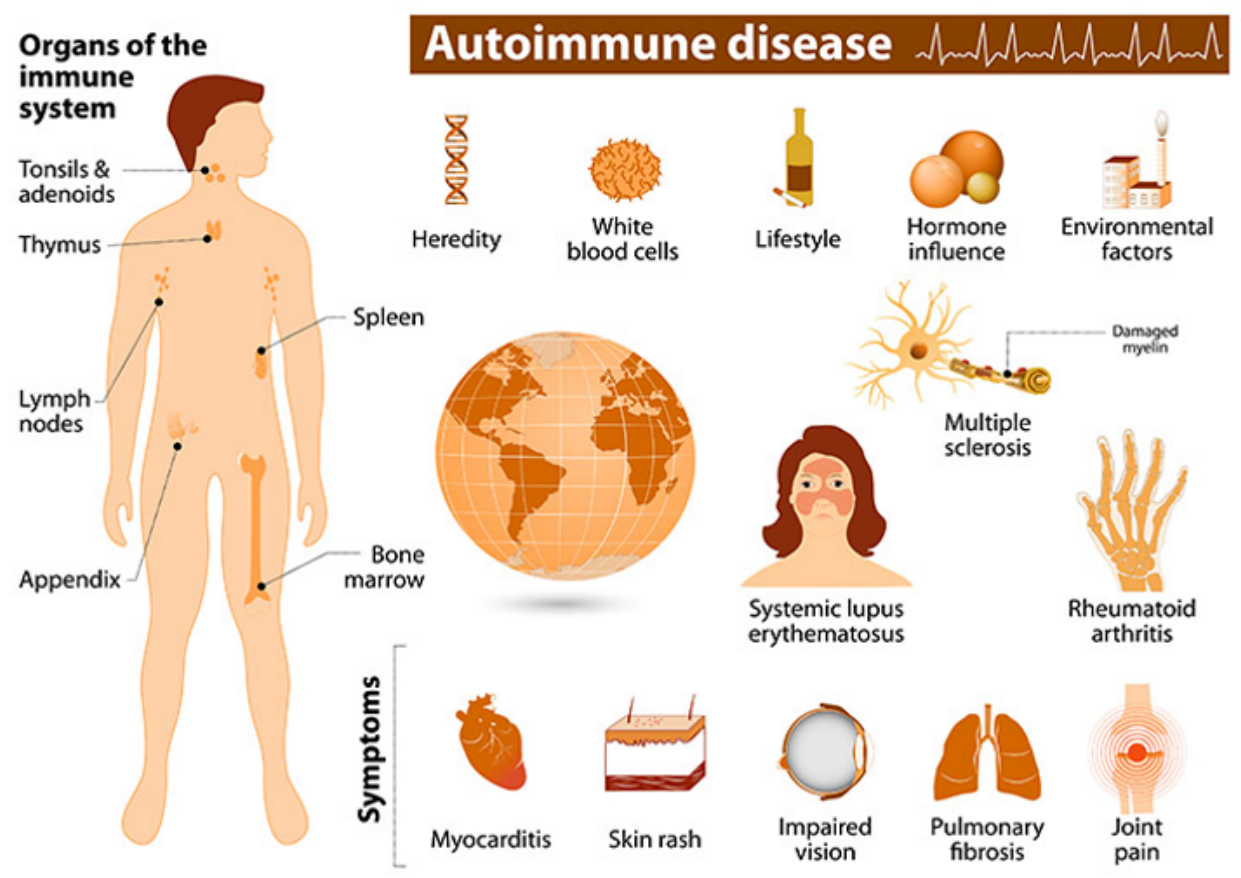

Figure 4

Schematic illustration of the link between (trace element interactions in-) organs of the immune system and development of autoimmune diseases. The probable role of trace elements in the incidence of systemic lupus is described under this disease in Table 1. Image by the U.S. National Institute of Environmental Health Sciences. 